\title{
A PRODUÇÃO dO SABER SOBRE A FLORESTA PELOS ASSENTADOS NA FAZENDA IPANEMA, IPERÓ (SP)
}

\author{
ANTONIO MACIEL BOTELHO MACHADO
}

Engenheiro Agrônomo

Orientador: Prof. Dr. MARCOS SORRENTINO

Dissertação apresentada à Escola Superior de Agricultura "Luiz de Queiróz", Universidade de São Paulo, para obtenção do título de Mestre em Ciências, Área de Concentração:

Ciências Florestais.

PIRACICABA

Estado de São Paulo - Brasil

Janeiro - 1998 
Dados Internacionais de Catalogação na Publicação (CIP)

DIVISÃo DE BIBLIOTECA E DOCUMENTAÇÃO - Campus "Luiz de Queiroz"/USP

Machado, Antonio Maciel Botelho

A produção do saber sobre a floresta pelos assentados na Fazenda Ipanema, Iperó

(SP) / Antonio Maciel Botelho Machado. - - Piracicaba, 1998.

133 p. : il.

Dissertação (mestrado) - Escola Superior de Agricultura Luiz de Queiroz, 1998. Bibliografia.

1. Assentamento rural 2. Educação ambiental 3. Floresta 4. Reforma agrária 5. Sociologia rural 6. Uso da terra 1. Título 


\section{A PRODUÇÃo DO SABER SOBRE A FLORESTA PELOS ASSENTADOS NA FAZENDA IPANEMA, IPERÓ (SP)}

ANTONIO MACIEL BOTELHO MACHADO

Aprovada em: 27.02 .1998

Comissão julgadora:

Prof. Dr. Marcos Sorrentino

ESALQ/USP

Prof $^{\mathrm{a}}$. Dra. Ângela Maria Silva Arruda

UFRJ

Prof ${ }^{a}$. Dra. Maria Dulce Bandiera Bergamim

ESALQ/USP

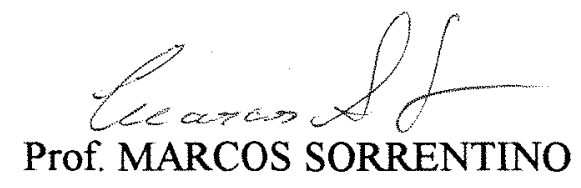

Orientador 


\section{IN MEMORIAM}

Geraldo Garcia,

Meu amigo, quase um irmão...

Você que me levou pela primeira vez em um assentamento rural em

Corumbá, Mato Grosso do Sul e daí para cá a questão agrária passou a fazer parte de minhas preocupações.

A sua caminhada, apesar de interrompida prematuramente, foi um exemplo para todos nós de seriedade, persistência, ternura e, principalmente, benevolência. Foi também uma luta permanente e reconhecida em prol de uma sociedade justa e igualitária. Tenha certeza, onde quer que esteja, que a sua vida não foi em vão, e que, como já disse o poeta, você foi imprescindível. 


\section{DEDICATÓRIA}

Ofereço este trabalho a todos os novos camponeses do Assentamento da Fazenda Ipanema, homenageando-os com uma poesia de um jovem do JUMAFI (Jovens Unidos de Mobilização da Fazenda Ipanema)

\section{A NATUREZA PREVALECE}

\section{Uanderson Mezavila Garcia}

A chuva chega repentina, em qualquer hora, de qualquer maneira, trazendo consigo uma forte neblina, insistente, persistente, mas passageira.

Não sei se vejo uma miragem, um belíssimo arco-íris em meio a um cerrado, desenhando o espetáculo na paisagem, tomando o dia ensolarado.

O balançar dos ventos nas folhagens, a magia de um verde encantado, demonstrando uma das grandes mensagens:

proteger a natureza ainda é um sonho dourado.

Muitos afirmam que cuidar da natureza não atrai vantagem, imagine como será o nosso cenário, qual será a nossa imagem, não havendo, ao menos, um arbusto solitário.

Raciocine e faça uma viagem, imagine como seria a natureza se não houvesse conscientização, seria como uma engrenagem, que gira rumo à destruição. 


\section{AGRADECIMENTOS}

Esta dissertação representa para mim um tempo... um tempo muito longo. $\mathrm{Na}$ realidade foram 12 anos. Período de reflexões sobre um não fazer. Um projeto iniciado, curtido, muito curtido e inacabado...abandonado. Não um arrependimento em si pelo não feito, já que muita coisa foi feita durante o projeto. Muitas relações técnicas e afetivas com os assentados de Corumbá e muita aprendizagem. Mas um vazio por algo que ficou no ar e que agora, os mesmos assentados (só que de um outro lugar) me ajudam a realizar. Por isso, o meu primeiro "muito obrigado" vai para eles. Os de Corumbá, que continuam no meu coração e os da Fazenda Ipanema que me acolheram por quase um ano e bem vivido.

Agradeço ao MST de São Paulo: Maria Rodrigues e Maria José (da CCA), Bill (da CONCAMP), Pardal (da CONCRAB). Em especial ao Boaventura, que abriu as portas do assentamento e da sua casa, onde fiquei alojado com minha companheira por toda a fase de campo. O Pedrinho, a Noêmia, Dona Aparecida, a Tilde, o Afonso e a Cristiane pela acolhida que nos proporcionaram.

A todos do Conselho de Representantes, aqui representados pelo Carlão, que apoiaram e entenderam de pronto o meu trabalho, sempre abrindo um espaço nas reuniões para meus informes.

Os técnicos do ITESP de Sorocaba, SP, que além de disponibilizarem materiais para a pesquisa ainda permitiram a minha participação em reuniões.

Ao pessoal da Embrapa de Colombo, na figura do Chefe da Unidade, Dr. Carlos Alberto Ferreira que me liberou para esta aventura. Uma lembrança especial ao pessoal da administração: o Sotomaior, o Antônio Carlos, a Eliane, a Sandra e a Joana, que sempre atenderam aos meus apelos. Ao pessoal do DOD: Maria do Rosário, Maria de Lourdes e o Flávio, solícitos e competentes, agradeço o apoio.

Aos professores do Departamento de Ciências Florestais da ESALQ, em especial: Prof. Pogiani, Prof. Álvaro e Prof. João Luiz que me deram muita luz 
em suas aulas. Ao professor Antônio Natal, pelo apoio dado em todos os momentos, através da coordenação do curso de pós graduação. Ao pessoal da Biblioteca e da Secretaria: Maria Alice, Fátima, Margareth, Jerfeson, Creisa, Olicina (da reprografia) e aos demais funcionários, minha gratidão.

Ao professor Ricardo Rodrigues, pelas longas conversas, orientações e visita à campo. Mais um amigo fruto deste trabalho. À Suzy pelo companheirismo e carinho.

Aos colegas da PG... estaremos sempre juntos, do lado 'esquerdo'... no coração. Fru (Fabiana) e Japi (Marco) vocês foram por mim escolhidos para receberem o beijo de agradecimento a tudo que a nossa turma representou para mim.

À Lhama (Cristina), Poti (Mônica) e Marisol (Azeneth), que nunca pouparam esforços para ajudar a turma de Iperó e que estiveram juntas na empreitada.

Em especial, quero agradecer ao Kibe (Sílvio) pela disponibilidade em socorrer-me durante as panes do computador.

À professora Maria Dulce Bergamin, que participou da qualificação como membro substituta e que, pela enorme competência, carinho, apoio a mim dispensado, assumiu uma cadeira definitiva tanto na banca de defesa da monografia quanto na nossa amizade.

À professora Ângela Arruda, que, lá do Rio de Janeiro, esteve sempre com a mão estendida (com uma boa bibliografia sobre RS). Uma amiga produto desta pesquisa, um beijão.

Ao professor Marcos Sorrentino, meu orientador, motivo pelo qual vim para a ESALQ, agradeço por todo o apoio recebido, nas sugestões, na infraestrutura - computador, livros... e na riqueza dos debates em aula de aula. Estaremos sempre juntos pela amizade construída.

A minha irmãs Nieta e Marly, os cunhados Romeu e Rudgero e a sobrinhada que sempre deram aquela força. À tia Dezinha sempre animando nas hora 
dificeis. Ao Dedé, sempre torcendo por mim. À vovó Yvone e à tia Zezé pelo apoio constante e carinho que vêm me dando todos esses anos.

A meus filhos Pedro, Carolina, João e André. Desculpem-me por esse final tenso. Vocês significaram grande parte da razão da minha continuidade nos estudos. Um beijo para os quatro.

A todos que me ajudaram e estiveram juntos, e que, pelo desgaste mental por hora sofrido, tenha esquecido de mencionar, minhas desculpas e junto, os meus agradecimentos.

Por fim, à Teresa, mais que companheira inseparável, colega de sala de aula, e de trabalho de campo, pela sua pesquisa de doutoramento. Como coorientadora informal, trouxe para mim a novidade da teoria das Representações Sociais, muito útil como ferramenta em minha vida profissional. Esteve sempre junto me alimentando com seus inesgotáveis conhecimentos e dando direção sempre que eu ameaçava perder o rumo. Um beijo e minha eterna gratidão. 


\section{SUMÁRIO}

Página

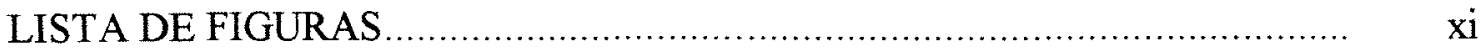

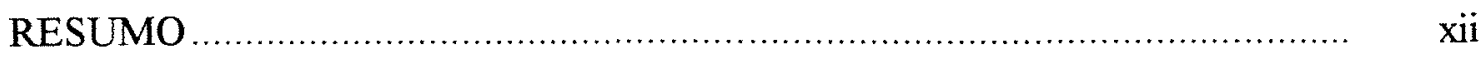

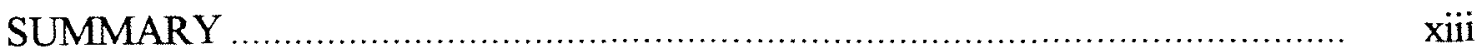

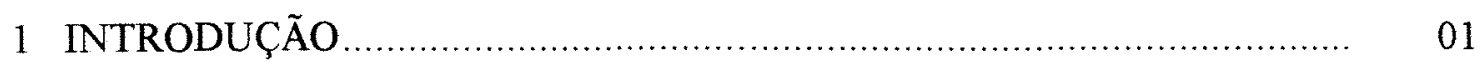

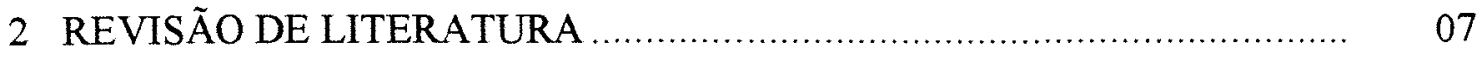

$2.1 \mathrm{O}$ meio ambiente e suas representações sociais ................................. 07

2.1.1 O ser humano e suas relações com a natureza .................................... 07

2.1 .2 A produção do saber sobre a natureza .......................................... 11

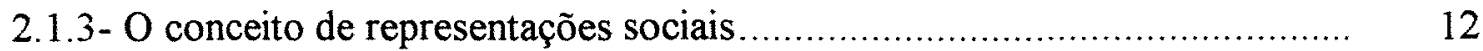

2.1.4 A produção de um saber sobre o meio ambiente ............................ 16

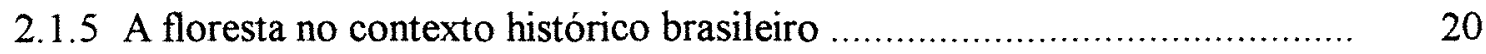

2.1.6 Produção do saber sobre a floresta e reforma agrária .......................... 29

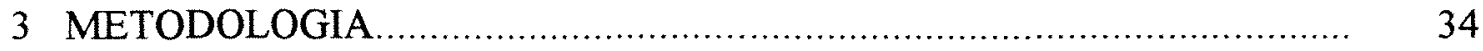

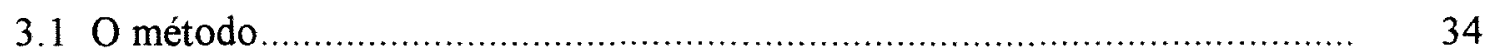

3.2 Procedimentos de coleta de dados ........................................... 35

3.2.1 Instrumentos utilizados...................................................... 35

3.2.2 Critérios de seleção da amostra .............................................. 37

3.2.2.1 Primeiro critério - referente à organização do assentamento ................. 37

3.2.2.2 Segundo critério - referente às áreas do assentamento ...................... 39

3.2.2.3 Terceiro critério - referente às áreas de reservas............................... 39

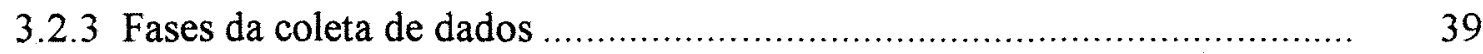

3.3 Procedimentos de análise dos dados ............................................ 42

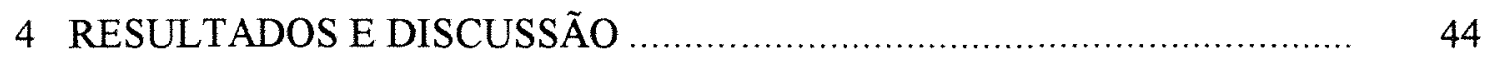

4.1 O contexto de produção das representações sobre a floresta ...................... 44

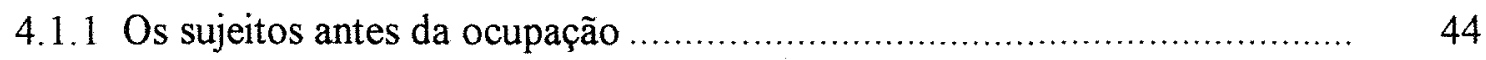


4.1.2 Formação do grupo social: a ocupação e o acampamento ……………..... 48

4.1.3 Consolidação do grupo social: os lotes definitivos ................................... 74

4.2 As representações da floresta pelos assentados ......................................... 82

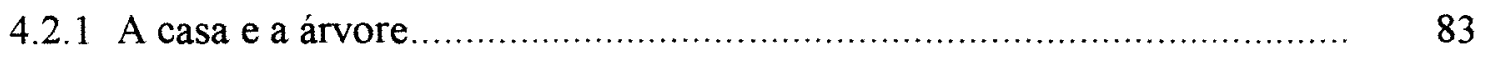

4.2.2 O lugar da floresta nos projetos agropecuários .................................... 85

4.2.3 A idéia de preservação e de uso das reservas ........................................ 87

4.2.4 Animais silvestres.................................................................... 91

4.2.5 As representações se articulam e orientam práticas ................................. 94

4.2.6 O papel da instituições na produção das representações sobre a floresta ... 97

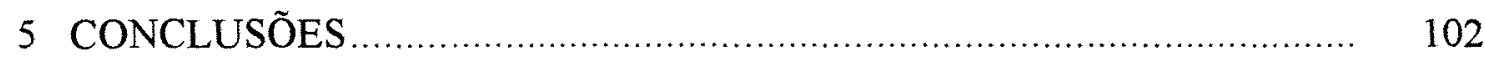

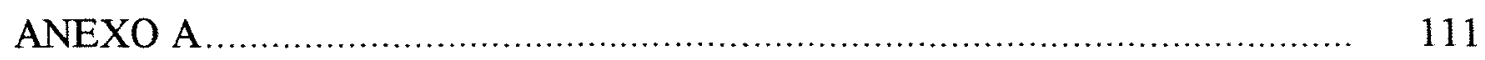

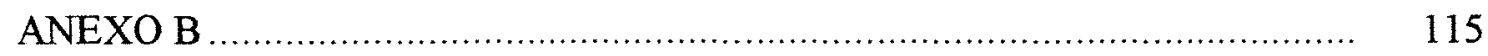

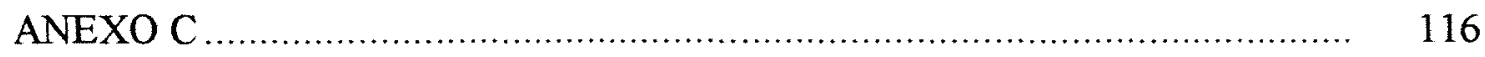

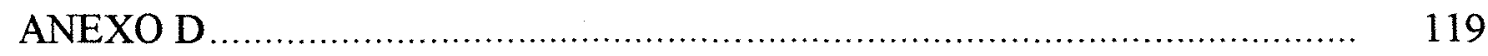

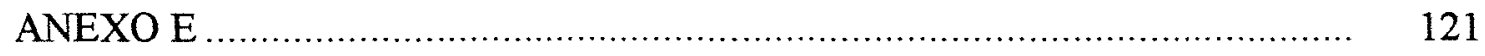

ANEXO F …

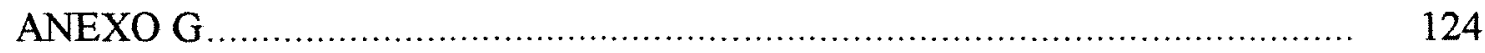

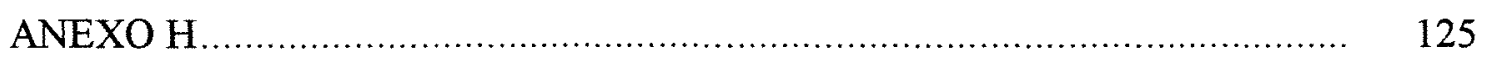

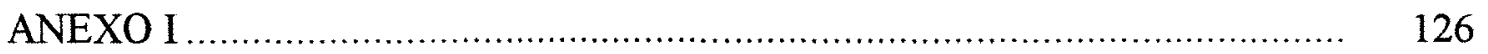

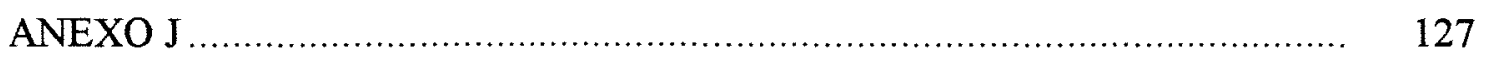

REFERÊNCIAS BIBLIOGRÁFICAS ................................................... 129 


\section{LISTA DE FIGURAS}

Página

1. Representação gráfica de um processo histórico vivenciado por um grupo qualquer, mostrando diferentes contextos existentes. ............................. 18

2. Quatro situações dos sujeitos em relação à organização interna do assentamento 38

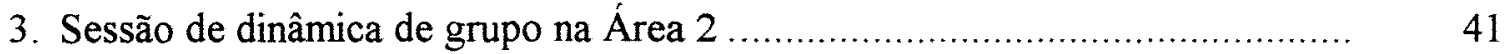

4. Desenho feito por assentada representando o sonho da volta ao campo.......... 48

5. Detalhe das habitações cobertas com plástico e caixas de papelão ................. 55

6. Detalhe de habitações no período do acampamento. ............................... 56

7. Desenho esquemático do projeto agropecuário .................................... 79

8. Desenho representando a presença do elemento arbóreo próximo à casa........ 83

9. Desenho representando a presença do elemento arbóreo próximo à casa ........ 84

10.Desenho esquemático incluindo o arboreto........................................ 86

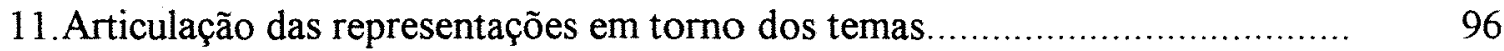




\title{
A PRODUÇÃO dO SABER SOBRE A FLORESTA PELOS ASSENTADOS NA FAZENDA IPANEMA, IPERÓ (SP)
}

\author{
Autor: ANTONIO MACIEL BOTELHO MACHADO \\ Orientador: Prof. MARCOS SORRENTINO
}

\section{RESUMO}

No sentido de se entender a dinâmica da produção das representações sobre a floresta pelos assentados da Fazenda Ipanema, Iperó (SP), a presente pesquisa desenvolve um estudo que teve como base a teoria das representações sociais de $\mathrm{S}$. Moscovici e partiu de uma análise histórico-social.

O trabalho compreendeu duas etapas: uma fase de pré-diagnóstico, através de visitas a campo e contatos com o grupo social e instituições presentes; outra fase onde foram realizadas sessões de dinâmicas de grupo e entrevistas semi-estruturadas. Foram utilizados, como instrumentos de análise, a história de vida, a observação participante e o desenho livre. A partir dai foi feita uma triangulação para a interpretação dos dados.

Os resultados apontaram para alguns temas em torno dos quais se nuclearam as representações: a moradia, o projeto agropecuário, a preservação, o uso das reservas e os animais silvestres. Pôde-se concluir que as representações da floresta surgidas em torno desses temas são ainda ambíguas e contraditórias, mas já mostram que existe um saber sobre a floresta circulando no grupo. 


\title{
THE PRODUCTION OF KNOWLEDGE ABOUT THE FOREST BY RURAL SETTLEMENT PEOPLE IN THE FAZENDA IPANEMA, IPERÓ (SP)
}

\author{
Author: ANTONIO MACIEL BOTELHO MACHADO \\ Orienting: Prof. MARCOS SORRENTINO
}

\section{SUMMARY}

In order to understand the production dynamics of the representations of the forests by the settlement of the Fazenda Ipanema, Iperó (SP), this work develops a study based on S. Moscovici's social representation theory, in a social-hystoric analysis.

The work had two phases: one of pre-diagnosys through field visits and contacts with the social group and institutions envolved; the other phase had sessions of group dynamics and application of semi-structured interviews. The life history, the participant observation and free drawing were utilized as tools for analyses. From there, a triangulation for a data interpretation were made.

The results pointed to some themes which atracted the representations: housing, farming projects, preservation and use of the reserves and wildlife. From these results, it was allowed to conclude that the forest representation and ambiguous and contradictory but there are some forest knowledge in the group. 


\section{INTRODUÇÃo}

"A realidade é uma coisa diferente e muito mais rica do que aquilo
que está codificado na lógica e na linguagem dos fatos (...).
Compreender a realidade significa, portanto, compreender o que as
coisas verdadeiramente são, e isto implica, por sua vez, a recusa de
sua simples facticidade".

Herbert Marcuse

A questão agrária volta a ser debatida na sociedade brasileira, com mais ênfase, a partir da abertura política que marcou o fim da ditadura militar no final dos anos setenta.

De lá para cá, a pressão dos movimentos populares, no que diz respeito à reforma agrária, vem exigindo que os sucessivos governos, democraticamente eleitos, realizem a distribuição dos latifúndios improdutivos para cidadãos 'sem-terra' com o objetivo de promover a justiça social.

Em 1984 surge o Movimento dos Trabalhadores Rurais Sem-Terra, o MST, que, além de coordenar nacionalmente as ações de reivindicação e ocupação de terras, passa a organizar a massa dos trabalhadores excluídos que almejam retornar ao campo e ampliar a base de apoio nos diferentes setores da sociedade.

Acampamentos do MST se multiplicam por todos os rincões do país, tanto traduzindo a imensa desigualdade social quanto mostrando a face das quatro milhões e novecentas mil famílias de 'sem-terra' existentes no Brasil, segundo as metas expressas pelo Plano Nacional de Reforma Agrária - PNRA (Folha de São Paulo, 03/08/96). 
No momento atual encontra-se em evidência o tema reforma agrária ecológica, que busca trazer para dentro das ocupações e assentamentos rurais uma maior preocupação com o meio ambiente e, também, a construção de modelos agrosilvopastoris sustentáveis mais adequados à realidade campesina. Isso possibilitaria tanto o alimento $\mathrm{e}$ subsistência quanto a geração de excedentes que possam contribuir com o abastecimento dos centros urbanos com produtos sadios, garantindo, com isso, a fixação desse novo camponês no campo, melhorando a distribuição da renda nacional e colaborando com a conservação dos recursos naturais - solo, ar, água, fauna e flora.

A ocupação é um processo que possibilita o contato inicial desse novo personagem com a natureza. A partir desse processo, os 'sem-terra' mantêm um relacionamento com determinados recursos florestais necessários para a implantação do acampamento - madeira para a construção dos barracos e lenha como fonte de energia para o preparo do alimento. Esse contexto torna-se, portanto, o 'locus' do processo educativo onde se aprende e se ensina, se constróem e se reconstróem sonhos e projetos de vida, e que vai ser fundamental na concretização de todas as representações construídas nessa práxis, em especial as representações da floresta. A partir daí, os projetos agropecuários advindos poderão estar mais próximo ou mais afastados de sistemas produtivos integrados com a floresta.

Dessa forma, torna-se pertinente uma pesquisa que procure entender os processos de produção do saber sobre a floresta a partir de representações sociais construídas nos diferentes contextos de um assentamento. Esta pesquisa se propôs a um estudo de caso no assentamento da Fazenda Ipanema, com vistas a entender a dinâmica desse saber.

Para explicar o processo de produção de um saber sobre algum objeto, que no caso desta pesquisa é a floresta, deve-se investigar o lugar que este objeto ocupa no 'espaço de vida' do grupo que está processando o saber. 'Espaço de vida' é um conceito tomado de empréstimo a Kurt Lewin (1965) para designar o espaço psicológico, isto é, o que interessa é a representação da floresta pelo grupo e não o espaço geográfico que esta ocupa no assentamento. No entanto, como as representações se produzem na 
atividade dos sujeitos e elas próprias orientam suas práticas, em um movimento constante entre pensar, sentir e fazer, o lugar geográfico da floresta no assentamento tornou-se o primeiro foco de observação do pesquisador.

O grupo social estudado convive com a floresta em determinadas condições geográficas. Observar onde está a floresta ou os fragmentos dela no espaço geográfico dos habitantes do assentamento constituiu uma forma de retratar o cenário dentro do qual se processam os conhecimentos. Pressupôs-se que esse retrato daria uma primeira visão do convívio possível com a floresta e os elementos que a compõem, auxiliando na definição da abordagem do tema com a população.

A essa observação aliaram-se os dados coletados em relatórios técnicos de alunos e professores da ESALQ ${ }^{1}$ e de outros documentos abaixo mencionados.

A Fazenda Ipanema, localizada em Iperó, SP, com área de 6.827 hectares, foi transformada pelo Governo Federal, em maio de 1992, na categoria de Floresta Nacional (FLONA), decreto $n^{\circ} 530$, sob a responsabilidade administrativa do IBAMA ${ }^{2}$.

Floresta Nacional é uma Unidade de Conservação prevista no Código Florestal (Lei Federal $n^{\circ}$ 4.771/65), porém sem uma definição muito precisa. Em 1982, o Plano de Sistema de Unidades de Conservação do Brasil caracterizou a Floresta Nacional como:

"uma área extensa, geralmente bem florestada, que contém consideráveis superficies de madeira comerciável em combinação com o recurso água, condições para sobrevivência de animais silvestres, e oportunidades para recreação ao ar livre e educação ambiental, mesmo após ter sofrido alterações antrópicas. Tem por objetivo a produção de madeira e água, a proteção dos valores recreativos e estéticos, manejo da fauna e educação ambiental" (IBDF/FBCN, 1982) ${ }^{3}$.

\footnotetext{
${ }^{1}$ Escola Superior de Agricultura Luiz de Queiróz

${ }^{2}$ IBAMA - Instituto Brasileiro do Meio Ambiente

${ }^{3}$ IBDF - Instituto Brasileiro de Desenvolvimento Florestal; FBCN - Fundação Brasileira para a Conservação da Natureza.
} 
Inserida no Sistema Nacional de Unidades de Conservação, Projeto de Lei ainda em tramitação no Congresso Nacional, Floresta Nacional é uma Unidade de Conservação que faz parte do "Grupo das Unidades de Manejo Sustentável". É uma área com "cobertura florestal de espécies predominantemente nativas e que se destina à produção econômica sustentável de madeira e outros produtos vegetais, à proteção dos recursos hídricos, às pesquisas e estudos, ao manejo da fauna silvestre e às atividades recreativas em contato com a natureza"4.

A Fazenda Ipanema possui áreas com cobertura florestal em diferentes estágios sucessionais e em diferentes níveis de degradação. Possui, ainda, florestas secundárias, áreas reflorestadas com espécies exóticas (eucaliptos) e áreas com pastagens abandonadas (Moitinho, 1995).

Na Fazenda Ipanema existe um patrimônio histórico de muita importância para o país, composto pelo sítio arqueológico Afonso Sardinha, datado de 1589, pelas instalações do Estabelecimento Montanístico de Extração de Ferro das Minas de Sorocaba, de 1810 e pela primeira fábrica de armas brancas do Império, com construções do século XIX. Este complexo histórico foi tombado em 1964 pelo IPHAN ${ }^{5}$.

Uma semana antes da assinatura do decreto presidencial de criação da FLONA de Ipanema, a Fazenda foi ocupada por 700 famílias de 'sem-terras'. Após muita negociação entre o governo e o MST ocorreu a divisão da Fazenda Ipanema e o reconhecimento do Assentamento pelo INCRA $^{6}$, Portaria $n^{\circ} 342$, de 04 de dezembro de 1995, restando para o IBAMA 5.069,25 ha; para o Ministério da Marinha ${ }^{7} 858,74$ ha; para o Ministério da Agricultura 495,90 ha; Campos Realengos 124,98 ha e Posses antigas 278,13 ha segundo documentos do MST. Nos quatro anos seguintes após a oficialização do Assentamento não haviam sido demarcadas oficialmente as terras por parte do INCRA. Somente em 1997, no momento da pesquisa, foram divididos os lotes

\footnotetext{
${ }^{4}$ Art. 21 do Projeto de Lei 2.892 , de 20 de maio de 1992.

${ }^{5}$ IPHAN - Instituto do Patrimônio Histórico e Ambiental

${ }^{6}$ INCRA - Instituto Nacional de Colonização e Reforma Agrária

${ }^{7}$ No Ministério da Marinha funciona o Projeto Experimental ARAMAR que visa a construção de um protótipo de um reator atômico para impulsionar submarinos.
} 
definitivos em área correspondente a 1.613,0 há, segundo documentação do MST (1996). As famílias assentadas já se distribuíam ao longo da fazenda ocupando áreas de dimensões aproximadas ao módulo a que teriam direito. Algumas outras instalaram-se em antigas casas e construções (baias, depósitos, etc.) existentes no local, adaptando-as em moradias provisórias. Nesse momento, aqueles que tiveram seus lotes demarcados em outros locais que não o ocupado estão em fase de mudança.

Culturas agrícolas de subsistência (feijão, arroz, mandioca e milho) foram sendo praticadas, ano a ano, inicialmente, de uma forma coletivizada e organizada pelo MST, depois, de forma familiar, restando apenas alguns serviços que permaneceram coletivos, como os referentes à utilização das máquinas e dos equipamentos das Associações.

A principal questão levantada em contatos com a liderança foi a morosidade na demarcação das terras, o que tomou muito tempo do Conselho de Representantes em articulações políticas para acelerar o processo, além de atrasar a implantação de infra-estruturas básicas e projetos familiares, como a construção das residências definitivas.

Não existe, no momento, um projeto agroflorestal coletivo e mais amplo para o assentamento. $\mathrm{O}$ que existe é um zoneamento superficial, que divide a área total do assentamento em três zonas de aptidão: uma para pecuária, a segunda para lavoura em geral e a terceira para hortaliças e fruticultura.

Dentro do assentamento restaram poucas áreas com cobertura florestal. Sobraram, apenas, algumas matas ciliares nos quatro córregos existentes, além de pequenos fragmentos isolados entre si.

Assim, considerou-se importante enfocar a floresta não apenas na forma contínua e densa que se apresenta na FLONA, mas, também, na forma de fragmentos e elementos florestais isolados (fauna e flora). Interessou pesquisar as representações sociais das configurações florestais definidas geograficamente.

Por não se conhecer como os assentados da Fazenda Ipanema estão construindo o seu conhecimento a respeito da floresta que está ali diante deles, fica dificil 
qualquer intervenção técnica que auxilie a implantação ou manutenção de projetos ambientais ou silviculturais na região do Assentamento e da FLONA ou a criação de reservas florestais individuais e coletivas na área explorada.

Dessa forma, a pesquisa se propôs, como objetivo geral, analisar o processo de produção do saber sobre a floresta pelos camponeses assentados na Fazenda Ipanema, Iperó, SP, com a finalidade de subsidiar ações educativas voltadas à incorporação do elemento arbóreo, e colaborar com a melhoria da qualidade de vida das populações assentadas.

Os objetivos específicos definidos foram: identificar, nos discursos dos sujeitos, os núcleos temáticos aglutinadores de representações da floresta pelos assentados; analisar como as representações se apresentam em torno desses núcleos temáticos; e explicar o processo de produção do saber sobre a floresta através da articulação das representações. 


\section{REVISÃO DE LITERATURA}

\subsection{O meio ambiente e suas representações sociais}

\subsubsection{O ser humano e suas relações com a natureza}

Procurando conhecer e transformar a natureza, o ser humano foi, gradativamente, descobrindo formas de resolver problemas fundamentais como a fome, 0 frio e demais questões relativas à solução de suas necessidades básicas, além de gerando, para ele próprio, novas necessidades.

Essas soluções nunca foram isoladas porque os humanos são seres que vivem em sociedade, ou seja, a atividade humana se caracteriza pela relação social estabelecida em grupos. Nenhuma ação individual pode estar fora da atividade social que lhe dá sentido.

Para caracterizar o processo de constituição do gênero humano Engels (1975), diz:

"Centenas de milhares de anos, na história da Terra (nada mais que um segundo na vida humana), seguramente se passaram antes que de um bando de macacos que trepavam às árvores, surgisse uma sociedade de seres humanos. Mas, finalmente, esta se organizou. E que voltamos a encontrar como diferença característica entre aquele bando de macacos e o gênero humano? O trabalho." 
As formas de dominar os animais e produzir os alimentos geraram a atividade organizada para estes fins - o trabalho, entendido como relação social e relação com a natureza. Os humanos, na relação com outros humanos, intervindo diretamente no seu ambiente e realizando atividades coletivas, passam a se constituir como sociedades. A dinâmica da relação com a natureza já não se dá mais por apenas alguns poucos reflexos, condicionamentos ou instintos próprios do antigo animal. Alguma coisa começa a ser edificada com essa nova relação social que vai diferenciá-los das demais espécies biológicas existentes no planeta. A organização social estabelecida para o cumprimento de um trabalho passa a ser identificada pelos elementos do grupo através de signos, que são construídos nessa relação e que vão, por sua vez, ampliando a capacidade desse grupo de interferir na natureza. Sinais, gestos, sons, passam a ser utilizados como formas de comunicação dentro dos grupos humanos, nesse jogo de sobrevivência na natureza. Com a capacidade simbólica sendo exercida, o ser humano amplia suas possibilidades sobre a natureza.

Essa forma de relação com o mundo só foi possível a partir do desenvolvimento da capacidade de significar as coisas, os objetos imediatos, as ações. A pedra deixa de ser apenas uma pedra, uma coisa qualquer na natureza e passa a ter o seu lugar, sua função, o seu papel. A pedra agora passa a ser a arma que mata, a ferramenta que constrói, o abrigo que protege, o colar que enfeita. Elementos simbólicos são reelaborados e compartilhados entre os seres humanos, modificando a natureza humana, que se constitui como produto histórico-social.

À medida que cada grupo humano estabelece seus diálogos, amplia a capacidade de representar e entender a natureza. A fala passa a ser a principal forma de troca simbólica, porém não a única, própria de cada grupo que as identifica. Tanto a fala quanto a organização para a realização do trabalho foram permitindo a produção de novos saberes e a geração de novos conhecimentos e tecnologias, e, cada vez mais, ampliando a consciência sobre a natureza e sobre a vida.

A visão que o ser humano constrói sobre o ambiente natural vai se alterando na sua História. Desde as comunidades tribais as sociedades modernas foram 
produzindo diferentes formas de se relacionar e de entender o espaço natural. Nas sociedades ocidentais a urbe passa a ser o lugar social mais avançado, mais protegido, onde as pessoas elaboraram suas existências e organizaram novas formas de atividade. $\grave{A}$ natureza e ao campo fica a função de prover os recursos necessários à manutenção das cidades: alimento, água e energia. Porém, ela não deixa de ter importância na sobrevivência do ser humano. A relação estabelecida entre campo e cidade e a visão sobre a natureza em cada fase da História é que se transforma. Do início da História social do ocidente até a Idade média, a natureza aparecia para o ser humano com uma dimensão infinita. As matas, os rios, o solo, as montanhas, os mares eram bem maiores que as suas necessidades.

As várias maneiras pelas quais as sociedades se organizaram, nos diferentes modos de produção até o feudalismo, deram início à modificações irreversíveis nos ambientes naturais. Essas sociedades dependiam diretamente da utilização dos recursos naturais disponíveis, em especial a floresta, substituindo-a pouco a pouco pelos campos agricultáveis. De acordo com Thomas (1988, p.230), "desde os tempos mesoliticos o progresso humano dependeu de arrancar e destruir as árvores com que a maior parte da terra estava coberta". $\mathrm{Na}$ Inglaterra, o desmatamento remonta a tempos antigos, sendo que a mata nativa desapareceu antes mesmo da chegada dos romanos. Até o final do período anglo-saxônico, grande parte do desmatamento já havia sido concluído. A floresta, segundo o autor, "fora considerada selvagem e hostil."

Com o cercamento dos campos, iniciado na Inglaterra, e com a seguida expulsão de muitos camponeses para a cidade, a fim engrossar o exército de reserva de mão-de-obra fabril, foi instaurado um dos períodos mais duros e dificeis da história da humanidade. Esse processo histórico de expropriação camponesa, que dissociava o trabalhador dos seus meio de produção, ocorreu na Europa por volta do século XVI e foi chamado por Marx (1968) de acumulação primitiva "porque constituiu a pré-história do capital e do modo de produção capitalista". Nesse período, a servidão já havia sido abolida cabendo aos camponeses expropriados constituírem-se como a base da nova organização social. Os trabalhadores, homens, mulheres e crianças foram se 
transformando em parte das máquinas, como engrenagens de um sistema mais amplo. A fábrica passou a representar o lugar privilegiado do trabalho, do ponto de vista do processo de acumulação do capital. Já não era mais permitido a todos o contato mais direto com a natureza. Esta tinha que se manter subordinada a um controle maior, que auferia concentração de renda e poder. Os trabalhadores tornaram-se 'livres' como força de trabalho, porém, com isso, são desapropriados de todos os seus meios de produção, inclusive da terra, transformando-se em mercadoria.

Nesse período, o campesinato que se manteve no campo estabeleceu-se dentro de novas relações sociais, sem a propriedade da terra, sem os meios de produção e subordinados a uma situação de assalariamento frente ao novo proprietário capitalista. Esse novo modo de produção determinou maneiras diferentes de ver e representar a natureza e que passam a orientar o que se espera dela.

No modo de produção capitalista, os impactos sobre o planeta se ampliaram, em especial no século XX, após a $2^{\mathrm{a}}$ Guerra mundial, onde o modelo industrial acelerou a degradação ambiental com a destruição de vários sıstemas naturais.

Em várias partes do planeta, principalmente no terceiro mundo, o extermínio de espécies animais e vegetais, macro e microscópicos, vem ocorrendo diariamente, além de outros fenômenos que surgiram em decorrência do desenvolvımento industrial, como a destruição da camada de ozônio, o efeito estufa, a chuva ácıda e os processos erosivos nas mais diferentes formas. Todas essas mudanças, fruto das ações antrópicas sobre o planeta, poderão causar re-arranjos adaptativos e evolutivos diferenciados, num futuro próximo, de forma ainda não previsivel pela ciência atual. Não se conhece, também, a capacidade da espécie humana em suportar e se adaptar a essas possiviveis transformações.

À medida que se dá o processo de urbanização, os humanos vão perdendo a consciência de que também são natureza. Quanto mais desenvolvem os seus meios de produção mais se confundem com as máquinas e produtos que produzem e inventam, o que vai engendrando um afastamento progressivo quanto ao espaço natural. Esse ser 
humano, fruto de uma sociedade industrializada, que cria, mas, ao mesmo tempo destrói, passa a produzir uma necessidade crescente de um contato direto com a natureza.

\subsubsection{A produção do saber sobre a natureza}

Ao longo de toda a história, como se viu, a atividade de trabalho foi o determinante no modo humano de se relacionar com a natureza. Em cada modo de produção específico, as relações sociais produziram maneiras próprias de ver e interferir na natureza.

A partir do momento em que agrupamentos humanos se dividem pela cidade e pelo campo, representações diferentes sobre esses ambientes são também produzidas. Williams $(1989$, p.11), refletindo sobre as representações inglesas campo/cidade que foram produzidas desde a antigüidade clássica, diz:

"o campo passou a ser associado a uma forma natural de vida - de paz, inocência e virtudes simples. À cidade associou-se a idéia de centro de realizações - de saber, comunicações, luz. Também constelaram-se poderosas associações negativas: a cidade como lugar de barulho, mundanice e ambição; o campo como lugar de atraso, ignorância e limitação."

No momento em que classes sociais se diferenciam ao longo de processos históricos específicos, mais uma vez, novas representações simbólicas são produzidas sobre seus ambientes e seus espaços, próprias para cada classe social desse contexto específico.

As representações do ambiente, seja ele rural ou urbano, são produzidas em cada período histórico característico e pelos personagens dessa história, de acordo com as classes sociais distintas. A visão que se tem do campo como um espaço cultivado, produtivo, modificado, que tem ligações com imagens de desenvolvimento econômico e progresso, em contraposição à idéia da natureza selvagem, nativa, isolada, com idéias ligadas a imagens de atraso, acomodação, está presa a uma perspectiva histórica num 
momento especifico. Williams (op. cit., p. 389), analisando a diferenciação das idéias de acordo com a posição social dos sujeitos diz:

"dentro de um mesmo periodo podemos ver que numa idéia - como a da Idade do Ouro $^{8}$ - uma semelhança aparente, ao ser examinada, acaba revelando-se um aglomerado de idéias diferentes, dependendo de seu usuário ser um aristocrata, um pequeno proprietário ou um trabalhador sem terra."

$\mathrm{O}$ autor ressalta que o senso comum não é homogêneo, mesmo que assim aparente. As idéias se transformam, se combinam, se misturam nas práticas sociais

Diegues (1996, p.64) referindo-se a dois grupos distintos presentes na floresta tropical da Amazônia - tribos indígenas tradicionais e colonos sulistas do Brasil deslocados por programas de colonização - mostra que para os primeiros, a floresta representa o "habitat conhecido e acolhedor, morada dos antepassados". Para os novos colonos, a mesma floresta representa um obstáculo a ser derrubado para a implantação do projeto agropecuário adotado. Ele conclui:

"não é simplesmente a natureza, as limitações geográfico-ambientais que motivam um tipo específico de exploração dos recursos naturais da floresta, mas sim as formas com que se configuram as relações sociais, suas racionalidades intencionais, seus objetivos de produção material e social."

Toda intervenção humana na natureza é acompanhada de um processo de representação simbólica que vai contribuir na tomada de decisões e ajudar na compreensão dos fenômenos que advém da ação.

\footnotetext{
${ }^{8}$ Período do Ouro foi o período subsequente ao fim do periodo feudal na Inglaterra e que, após a guerra civil (16+2-1649) entre o rei e o parlamento liderado por Cromwell, se seguiu uma hegemonia dos proprietários de terra capitalistas ampliando a política de cercamento dos campos.
} 


\subsection{3- $O$ conceito de representações sociais}

O estudo das representações sociais (R. S.) tem origem na sociologia clássica do final do século passado. Tendo sido introduzido por Émilie Durkheim, o conceito de "representações coletivas" procurava explicar determinadas categorias de pensamento através das quais uma determinada sociedade elabora e expressa suas realidades. Segundo Durkheim (1978), as representações coletivas são:

"O produto de uma imensa cooperação que se estende não apenas no espaço, mas no tempo; para fazê-las, uma multidão de espiritos diversos associaram, misturaram, combinaram suas idéias $\mathrm{e}$ sentimentos; longas séries de gerações acumularam aqui sua experiência e saber".

Essas representações coletivas eram para o autor, um produto social onde os indivíduos seriam apenas os portadores e usuários dessas representações, as quais seriam produzidas pela sociedade. Portanto, não necessariamente conscientes do ponto de vista individual. Durkheim estudava este conceito para um tipo de sociedade, situada na virada do século passado, que tinha toda uma lógica e uma organização bem mais estruturadas do que as existentes hoje. A religião, a moral, a cultura, as tradições possuíam conotações profundas e arraigadas que "poderiam exercer sobre o indivíduo uma espécie de coerção" (Minayo, 1996, p. 159).

Minayo (op. cit.) relaciona várias correntes do pensamento sociológico que se detiveram no aprofundamento da questão da representação social. Algumas dando seqüência à linha de Durkheim, como no caso de Sapir, Malinowski e Kroeber. Outras tiveram base na sociologia compreensiva representada por Max Weber e na fenomenologia em Schutz. Mais uma grande corrente existente é a escola marxista, tendo na 'Ideologia alemã' de Karl Marx, a maior reflexão sobre o tema. Marx analisa nessa obra, o conjunto de filosofias da época e a produção da consciência de classe. Antonio Gramsci, um marxista italiano da década de 20 , discute em seus "escritos" a questão do senso comum como uma forma de representação e a sua importância no trabalho 
pedagógico de construção da contra-hegemonia. Essa escola marxista, segundo a autora, introduz a questão das classes sociais nas representações sociais

A partir da década de 50, a psicologia social segue, com G. W. Allport, o rumo do positivismo de Augusto Comte, encaminhando a vertente americana da psicologia social para um enfoque experimental estritamente quantitativo e de caráter apenas causal, dando origem à psicologia de opinião, centralizada quase que exclusivamente no indivíduo. (Far, In: Jovchelovitch, 1994, p.34).

Moscovici (1961), inaugura uma nova escola na psicologia social que, partindo da sociologia de Durkheim, avança na teoria das 'representações', abandonando o termo 'coletivas', de conotação mais cultural e assumindo o termo 'social' que daria maior mobilidade para explicar fenômenos do conhecimento numa sociedade moderna, mais dinâmica, mais fluida, onde a informação gira numa rapidez mais assombrosa, do que naquele tipo de sociedade que Durkheim conheceu.

As R. S. são para Moscovici (op. cit.) "as conversações, dentro das quais se elaboram as ideologias, os saberes populares e o senso comum". É uma teoria centrada na relação epistemológica entre o sujeito e o objeto. Através da sua atividade, o sujeito "constrói tanto o mundo como a si próprio" (Guareschi, In: Jovchelovitch, op. cit. p.20). Por fim, estabelece uma síntese entre fenômenos cognitivos, afetivos e sociais que na realidade estão profundamente ligados

Segundo a definição de Jodelet (1988, p.13), a R. S. é "uma forma de conhecimento, socialmente elaborada e partilhada, tendo uma visão prática e concorrendo para a construção de uma realidade comum a um conjunto social". A autora apresenta cinco características da teoria das representações sociais importantes para a sua compreensão, a saber: a) o aspecto imaginante (figurativo) da representação é inseparável do seu aspecto significante; b) R. S. não é uma reprodução passiva de um exterior num interior. Em suas acepções, a teoria coloca em jogo a intervenção do imaginário individual ou social; c) está presente nas interações significativas entre o sujeito e o mundo; d) implica que se tenha sempre uma parte de atividade de construção e de 
reconstrução no ato da representação. Como sujeito social a atividade é tanto simbólica como cognitiva; e) possui um caráter criativo e autônomo.

Para Jodelet (op. cit., p.17), dentro de uma visão cognitivista, onde o sujeito constrói suas representações, existem duas dimensões através das quais essas representações são constituídas a partir de uma atividade social, que são as dimensões de "contexto" e a de "pertença". Como "contexto" a autora entende as situações onde existem interações sociais ou onde os sujeitos encontram-se frente a estímulos sociais. A dimensão de "pertença" parte do princípio que o sujeito é social e que por isso "faz intervir na sua elaboração idéias, valores e modelos que ele traz do grupo social ao qual pertence ou das ideologias veiculadas na sociedade".

Spink (1993, p.93) propõe um modelo de análise das representações sociais que parte da noção de 'contexto', mas que não elimina a dimensão que Jodelet chama de 'pertença'. Diz a autora: "as R. S. enquanto produtos sociais, têm sempre que ser remetidas às condições sociais que as engendram", lugar onde se processam as elaborações das representações. A autora também define que o contexto deve ser entendido a partir dos metassistemas sociais que são as determinações estruturais da sociedade e as relações sociais estabelecidas nesse contexto.

Spink (In: Jovchelovitch, op. cit., p.121) se refere, ainda, aos diferentes tempos históricos que permeiam a construção dos significados sociais: o tempo longo (imaginário social), o tempo vivido (que engloba o processo social do grupo em questão) e o tempo curto de interação (período onde se processa a funcionalidade das representações). O contexto, neste modelo passa a ser "intertextual", pois considera o texto sócio-histórico, raiz da subjetividade, e o texto - discurso, que constitui as relações sociais estabelecidas.

Resta entender os processos pelos quais se produzem as $\mathrm{R}$. S.

Moscovici (op. cit.) descreveu os dois processos que acontecem durante a transformação de um conhecimento em R. S. que são: a 'objetivação' e a 'ancoragem'.

Jovchelovitch (op. cit., p.81) coloca que "a objetivação e a ancoragem são formas específicas em que as representações sociais estabelecem mediações, trazendo 
para um nível quase material a produção simbólica de uma comunidade e dando conta da concreticidade das representações sociais na vida social".

A 'objetivação' segundo Jodelet $(1988$, p.21) é um processo que "se articula a uma característica do pensamento social, que é a propriedade de tornar concreto o abstrato, de materializar a palavra (...) dar textura material às idéias, fazer corresponder coisas às palavras e dar corpo a esquemas conceituais". Sá (In: Jovchelovitch, op. cit.) diz que objetivar é "a função de duplicar um sentido por uma figura, dar materialidade a um objeto abstrato, "naturalizá-lo"'.

A 'ancoragem', segundo Jodelet (op. cit., p.29), "é um processo que diz respeito ao enraizamento social da representação e de seu objeto". Para Sá (op. cit.) é o processo de "duplicar uma figura por um sentido, fornecer um contexto inteligivel ao objeto, interpretá-lo". Arruda citando Moscovici (In: Spink, op. cit., p.237) diz que "ancoragem é trazer as representações sociais às categorias e imagens cotidianas, ligando-as a um ponto de referência reconhecível".

\subsubsection{A produção de um saber sobre o meio ambiente}

A teoria das representações sociais, reconhecida por Moscovici como verdadeira teoria do senso comum, torna possível apreender como um determinado grupo social está se apropriando de conceitos, idéias e valores que circulam na sociedade. Hoje, torna-se urgente explicitar o entendimento que a população do campo tem da importância da conservação/preservação e da necessidade de incremento de áreas florestais na zona rural. Como uma comunidade percebe e re-elabora, em suas práticas sociais, conceitos como preservação, conservação, poluição, contaminação e outros temas ambientais?

Como diz Sá (In: Spink, op. cit., p.25-6):

"As explicações então veiculadas vão além do que chamaríamos de simples opiniões sobre os assuntos ou atividades isoladas em relação aos objetos sociais neles envolvidos. Comumente, fazem uma articulação ou combinação de diferentes questões ou objetos, segundo uma lógica própria, em uma estrutura globalizante de implicações, para 
a qual contribuem informações e julgamentos valorizativos colhidos nas mais variadas fontes e experiências pessoais e grupais".

A partir dos conceitos da teoria das R. S. acima descritos, pode-se estabelecer um esquema ilustrativo da dinâmica da R. S. para se explicar a construção de um saber cotidiano.

O modelo proposto está representado na Figura 1. Trata-se de um esquema onde se pretende visualizar um processo histórico vivenciado por um grupo qualquer e mostrar, na circulação das informações, o processo de construção das $\mathrm{R}$. S. nos diferentes contextos existentes. Esse esquema estará sempre se ampliando, pois no cotidiano, representações vão surgindo, novas atividades vão sendo realizadas, enfim, ele estará sendo constantemente incrementado, ampliado, revisto, gerando novas superficies que serão os futuros contextos.

A parte inferior da figura representa o tempo histórico, tendo na sua extremidade inferior o 'tempo longo', locus do imaginário social, a cultura, os mitos, as tradições, o tempo de seus antepassados, as raízes mais profundas do grupo.

A base inferior do desenho (seção menor do cone), representa o momento inicial de socialização deste grupo, quando se configurou o período de constituição do grupo como um coletivo.

A massa total da seção do cone representa o 'tempo vivido', ou seja, as experiências da vida comunitária do grupo em questão. É a história do convívio social.

A superficie superior representa o momento presente, o 'tempo curto' segundo Spink (1993), o locus de intensa atividade social, o trabalho cotidiano que está sendo planejado e executado pelos sujeitos, a troca de conhecimentos e informações que estão permanentemente circulando, o espaço mediado pelas forças hegemônicas, as instituições presentes, o aparelho de Estado etc.

Se uma informação nova penetra nesse contexto, ela vai sofrer diferentes leituras individuais e coletivas que vão se amontoando, se fundindo. No indivíduo, os processos de objetivação e ancoragem são imediatamente postos em funcionamento a fim de decodificar, interpretar, traduzir e, finalmente, produzir o entendimento necessário da 
informação. A situação informada é imaginada pelos sujeitos a partir de um quadro de referências anteriores. Situações já vividas como positivas ou negativas servem de ancoragem para a nova situação.

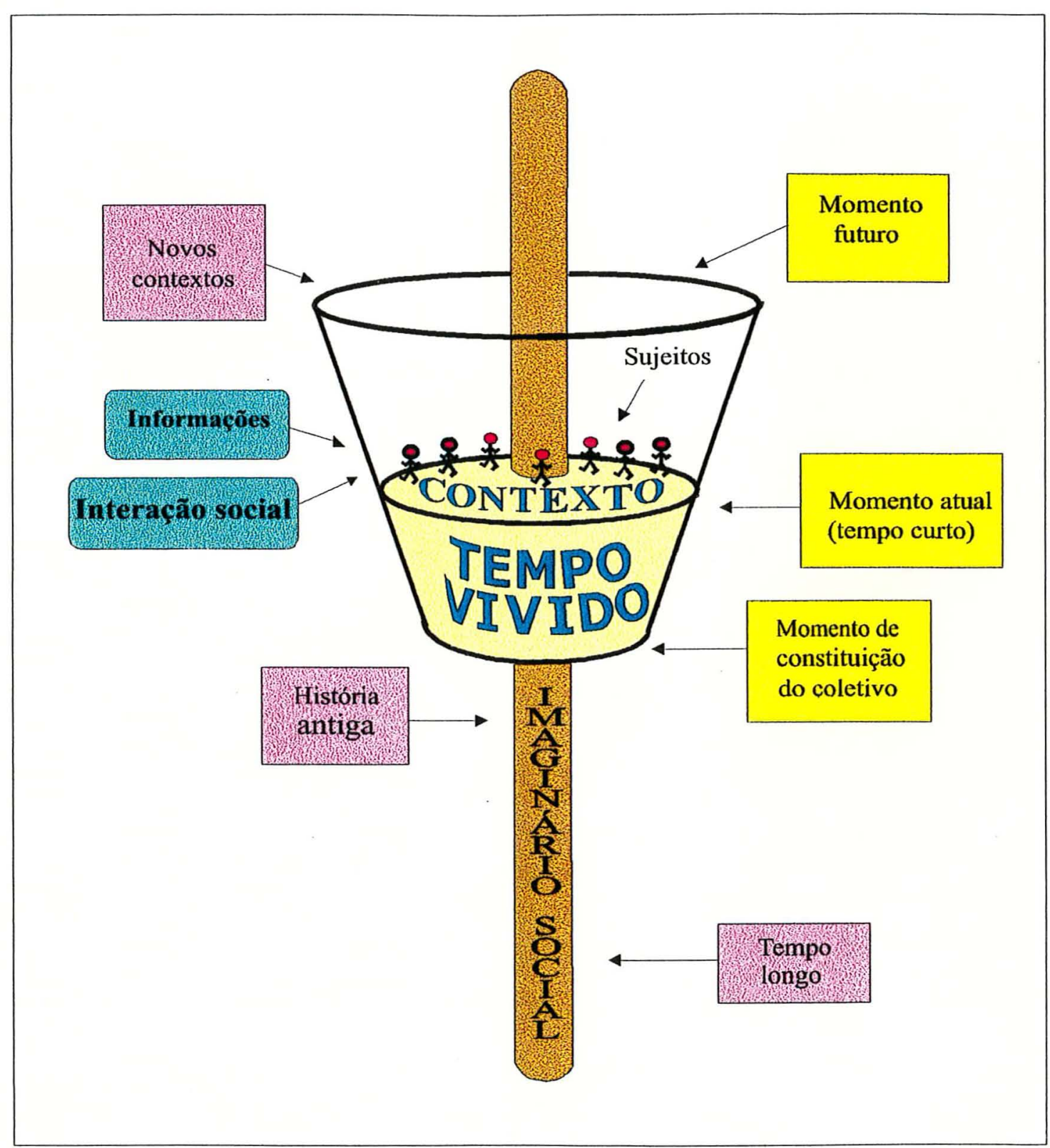

Figura 1 - Representação gráfica de um processo histórico vivenciado por um grupo qualquer, mostrando diferentes contextos existentes. 
A representação se dará a partir de um coletivo, mas se processará no indivíduo que responderá, ou não, com um novo re-arranjo em sua prática social. Novas práticas, novas atividades e, possivelmente, modificações nas relações sociais anteriormente estipuladas produzirão novos contextos, abertos a novos 'inputs', novas tramas de comunicação e, conseqüentemente, novas representações sociais.

Esse foi o esquema teórico que orientou toda a pesquisa 'A produção do saber sobre a floresta pelos assentados na Fazenda Ipanema, Iperó (SP)'.

\subsubsection{A floresta no contexto histórico brasileiro}

"Pode-se dizer que não encontramos nada de proveito". Assim, numa carta, o piloto genovês Américo Vespúcio, a serviço de Portugal, expressa a sua decepção quando chegou no novo mundo recém descoberto e não encontrou as facilidades previstas - o ouro, as especiarias ou os produtos idealizados pelos europeus achando, apenas, nativos nômades e um litoral coberto de florestas.

No meio dessa floresta havia uma árvore muito parecida com outra existente no oriente cuja madeira se prestava para o fabrico de tintas, o pau-brasil. Esta árvore foi motivo de acirradas disputas entre portugueses e corsários franceses. Os últimos, desrespeitando a bula papal que dividia o Novo Mundo entre Portugal e Espanha, participavam furtivamente da exploração do pau-brasil, competindo com os que se consideravam os 'legítimos' donos da terra descoberta, os portugueses. A extração impiedosa de madeira nativa causou a destruição de grandes extensões de matas no litoral brasileiro, em especial, nas áreas de maior ocorrência do pau-brasil, da região de Pernambuco até o sul da Bahia. Segundo Prado Junior (1985), foi outorgado pelo rei, em 1501, a Fernando de Noronha, a única concessão oficial para a extração do pau-brasil, desta forma ele deve ter sido um dos maiores responsáveis pela devastação deste recurso natural. 
A exploração florestal do pau-brasil, que durou algumas poucas décadas durante o século XVI, foi a primeira atividade econômica realizada no Brasil e, por ter sido muito intensa, entrou rapidamente em decadência frente à quase extinção da espécie.

A partir de 1530 , o rei de Portugal, preocupado com a manutenção do grande território além-mar, que se mantinha permanentemente visitado por intrusos comerciantes navegadores, resolveu instalar um sistema de colonização, através de doze capitanias hereditárias distribuídas ao longo da costa brasileira. Aos donatários cabia o controle e a gestão das suas capitanias, além do investimento nas atividades de sustentação econômica do patrimônio. A maioria delas, com severas dificuldades de implementação, optaram por projetos de monocultura açucareira, produto que estava em grande ascensão na Europa.

O sistema produtivo adotado era o sistema de exploração em 'plantation', ou seja, grandes latifúndios que, no início, utilizavam a mão-de-obra indígena disponível e, depois, a dos negros escravizados. Este modelo agrícola causou, na nossa história, a segunda grande pressão sobre a cobertura florestal nativa restante. Primeiro, na planície litorânea do extremo nordeste (Pernambuco) e, a seguir, no recôncavo baiano.

Com a destruição das matas para o plantio da cana-de-açúcar, toda essa região nordestina passou a ter uma redução da disponibilidade de energia (lenha) para manter as usinas em funcionamento. A lenha tinha que ser deslocada por muitas léguas, 0 que causou o aniquilamento de muitos engenhos (Prado Junior, op. cit., p.88).

No século XVII, a colonização chega de vez à Amazônia. Por ser uma região de dificil penetração, a ocupação desta gigantesca região se dá a partir da foz do rio Amazonas, na região da cidade de Belém do Pará, que é fundada em 1616, dirigindose na direção do rio Negro. Daí, surge a cidade de Manaus.

O interesse econômico maior na Amazônia sempre foi voltado a atividades florestais extrativistas. Prado Junior (1986, p.211) referindo-se à colonização da região diz que: "não se (a) compreende sem esta análise da atividade principal e quase única que nela se pratica; a colheita dos frutos da floresta", o cravo, a canela, a castanha, a 
salsaparilha, o cacau, a borracha, sem contar a infinidade de madeiras, além dos produtos de origem animal, o peixe, a caça e a tartaruga.

A questão madeireira amazônica nesse período era extremamente dificultada pelas condições ambientais ribeirinhas que limitavam a penetração do explorador na floresta e a subsequiente retirada das toras, além da dispersão espacial em que as essências florestais importantes se encontravam. Com isso, a floresta amazônica se manteve praticamente intacta até a metade do século atual.

Já no final do séc. XVIII, a coroa portuguesa procura soerguer a 'decadente e semi-extinta' marinha portuguesa. Com isso, caberia à colônia contribuir com a madeira necessária à utilização nos estaleiros aqui construídos. Nesse período, já se encontrava em vigor o decreto lei, assinado pelo Marquês de Pombal, que proibia o corte das madeiras consideradas de valor, 'de lei', por exigência de D. José I, que reinou em Portugal de 1750 a 1777. Porém, pouca contribuição pôde ser dada pela colônia, uma vez que o estoque madeireiro já era, nesse período, quase inexistente. Por falta de recursos técnicos e organização, a indústria naval instalada em Salvador, Bahia, não evoluiu. Em 1810 a coroa transfere aos ingleses a exploração madeireira, já visando a construção das linhas ferroviárias.

No nordeste, até o séc. XVIII, alguns remanescentes florestais nativos ainda eram encontrados na Paraiba, em Alagoas e, por fim, em algumas reservas na comarca de Ilhéus, na Bahia.

A respeito da legislação da época que visava a proteção dos recursos madeireiros, Prado Junior (1986, p.217) assim escreve:

'Depois de várias ordens, determinações e disposições legais sobre o assunto - como, além das cláusulas já referidas que se incluáam nas "cartas de sesmaria", Regimentos de 12 de setembro de 1652, §12, e de 13 de outubro de $1751, \S 29$, que proibiam os referidos cortes e queimadas - veio a Carta-Régia de 13 de março de 1797, que pretendeu regular o assunto de uma forma geral e definitiva. Reservaram-se à coroa todas as matas e arvoredos a borda da costa e dos rios que 
desembocassem diretamente no mar, e por onde, em jangadas, se pudessem conduzir os paus até a praia. Proibiu-se a concessão de sesmarias nestas áreas, e as existentes deveriam ser desapropriadas. Estas medidas tentaram-se pôr em prática, mas não surtiram efeito. Criou-se então a Conservadoria das matas, que deveria controlar todo o serviço de cortes reais e impedir as devastações."

$\mathrm{Na}$ região do estado de São Paulo os ciclos agrícolas que se sucederam aconteceram na planície costeira até o final do séc. XVIII. A expansão do ciclo canavieiro paulista vai acontecer somente no séc. XIX, e já não mais na faixa litorânea, mas sim, no planalto interior. A cultura do café também tem sua origem no sopé da Serra do Mar, somente adentrando para o interior após a construção das primeiras ferrovias. Nesse sentido, grandes extensões da Mata Atlântica desde o Espírito Santo até São Paulo deram lugar à cafeicultura.

Na realidade, o café da região sudeste tem o seu início na cidade do Rio de Janeiro, nas matas da Tijuca. Segue na direção de Minas Gerais e São Paulo, e por fim, no estado de Espírito Santo, onde, naquela época, não conseguiu boa produtividade. No norte e no nordeste o café foi disseminado como uma cultura promissora, mas, por razões ecológicas, não evoluiu como no centro-sul.

$\mathrm{Na}$ segunda metade do século passado, assim como o pau-brasil, a canade-açúcar, o algodão, é a vez da crise da lavoura cafeeira. Após quase um século de prosperidade segue-se um período de estagnação e, a seguir, a decadência. A causa, segundo Prado Junior (1985, p.162), foi o esgotamento dos solos causado pelo tipo de agricultura que sempre foi praticada no Brasil, que não se preocupava com a manutenção dos recursos naturais.

Com a falência da atividade cafeeira, acontece no Rio de Janeiro a primeira experiência em recuperação florestal de que se tem notícia no país. Coelho Netto e Abreu, citados por Arruda (1995), diz o seguinte:

"Os primórdios da luta pela preservação da natureza no Rio de Janeiro talvez se situem após a devastação causada pelo plantio do café no Maciço 
da Tijuca. É, ao menos em parte, graças à dedicação do Major Manuel Gomes Archer, nomeado pelo governo para coordenar os trabalhos, e uns poucos escravos que no início da década de 1870 iniciaram o reflorestamento, que hoje a cidade usufrui da Floresta da Tijuca".

Outra atividade exploratória florestal que teve início nessa fase colonial do século XVII foi a extração da erva mate. Encontrada em estado nativo nas matas de araucária no sul do país, em especial na região dos campos curitibanos, face oriental da Serra do Mar, essa atividade econômica passou a ser a mais forte da região, com comércio para os países platinos: Argentina e Uruguai, grandes consumidores.

A erva-mate, catalogada primeiramente por Saint-Hilaire com o nome científico de Ilex paraguarienses, se apresenta na mata com um porte de até (25) vinte e cinco metros de altura e um diâmetro à altura do peito de 25 (vinte e cinco) centímetros (Carvalho, 1994, p.281). Os produtores, ou ervateiros, realizavam a poda nos galhos laterais no interior da mata. Este tipo de extrativismo nunca chegou a comprometer o ecossistema, uma vez que era uma prática realizada somente uma ou no máximo duas vezes por ano. Nos períodos correpondentes à entre-safra o erval se mantinha em pousio, o que permitia a sua recuperação.

A questão florestal volta ao cenário já no século $\mathrm{XX}$, através dos plantios pioneiros de eucaliptos, realizados pelo Dr. Navarro de Andrade, no ano de 1919. Tratava-se de uma essência exótica trazida da Austrália, que plantada inicialmente em São Paulo, apresentava boa desenvoltura (Souza, 1957). Espécies do gênero Pinus, nativa da América do Norte e Caribe, também foram introduzidas depois do eucalipto. Ambas as espécies apresentavam um crescimento acentuado nas condições edáfoclimáticas brasileiras, usadas como matéria prima para energia, dormentes, construção civil e para a indústria de papel e celulose.

Em 1941, foi criado o Instituto Brasileiro do Pinho, que se propunha a implementar grandes reflorestamentos para o aumento da oferta da madeira através do Pinheiro-do-Paraná (Araucaria angustifolia), além de outras coníferas exóticas. 
Os plantios seguiram uma tradição de exploração monocultural, o que gerou muita polêmica quanto aos prejuízos ambientais causados pela atividade emergente. Como não havia nenhuma preocupação ambiental por parte dos produtores naquele período, muitos plantios foram realizados em substituição à cobertura florestal nativa, causando acentuada redução da biodiversidade em vários estados.

A década de 50 é importante para se entender o contexto florestal pois foi na conjuntura política dessa época que foi viabilizado o crescimento industrial nacional como alternativa à longa crise do setor primário, único responsável pela manutenção do equilíbrio da balança de pagamentos através das exportações dos produtos agrícolas. Nesse momento, se ampliou a política já iniciada nos anos 30 , de substituição das exportações, colocando o setor industrial à frente da economia. Segundo Furtado (1983, p.31), "nesse período o estado se empenha a fundo em ampliar a base do sistema industrial que surgira da crise da economia primário-exportadora". Segundo o autor, o Estado cria meios de atrair capital e tecnologia externa, ampliando o parque industrial, forçando uma acumulação de capital em contraposição às décadas anteriores, pois no modelo agro-exportador essa acumulação não aconteceu.

Mais tarde, a idéia da construção de Brasilia trazia em seu bojo um sentido de integração nacional, explicitada pelo então presidente da república, Jucelino Kubitschek de Oliveira. A idéia básica era a ampliação da capacidade de comércio interno pela centralização territorial do poder e o alargamento da fronteira agrícola, sendo o cerrado uma 'esperança'. Apesar dos fatores limitantes quanto a fertilidade dos solos e ausência de tecnologias agrícolas apropriadas, a utilização do cerrado passou a ser um desafio. O Estado subsidia a indústria, mas sob forte nacionalização das atividades produtivas, com a intenção de diminuir as importações de insumos. Surgem as indústrias químicas, metalúrgicas e siderúrgicas, de cimento e as empresas do ramo do papel e celulose.

O pós-64 e a década de 70 ficaram marcados pela dura intervenção militar, com a adoção de um modelo de desenvolvimento econômico imposto à nação que ficou conhecido como 'milagre brasileiro'. Basicamente, o modelo se baseava num conjunto de 
medidas e ações que visavam a modernização do parque industrial para geração de produtos e insumos, grandes obras faraônicas como Itaipú, a Transamazônica e a ponte Rio-Niterói, como exemplos, além da modernização do setor agrícola, inserindo-o no circuito capitalista de produção.

Seguindo as orientações da 'Revolução Verde'", esse modelo, concentrador de renda, deixou graves conseqüências econômicas, sociais e ambientais à história do Brasil gerando uma dívida externa da ordem de bilhões de dólares, além de um processo inflacionário com sérios efeitos sobre a recessão e o desemprego estrutural instalado na economia pós-milagre. Existem autores que vêem correlação entre a opção por este modelo econômico pelos militares e seu atrelamento aos desdobramentos do Plano Marshall, voltado para a hegemonia financeira dos grandes monopólios existentes nos EUA, Japão e Alemanha, a partir da abertura da economia à participação de multinacionais.

Sobre a modernização da economia agrária, Fernandes (1972, p.198), diz que ela:

$$
\begin{aligned}
& \text { "não é, em si e por si mesma, um fator de mudança estrutural da } \\
& \text { situação ou superação efetiva das iniqüidades sócio-econômicas, } \\
& \text { culturais e políticas. Com frequeência, ela se opera sem afetar } \\
& \text { profundamente a concentração social da renda e do poder. Em países } \\
& \text { como o Brasil, nos quais não há nenhuma tradição democrática, ela } \\
& \text { pode ser manipulada de maneira a incrementar as desigualdades } \\
& \text { existentes e a aumentar a eficácia dos controles sociais diretos e } \\
& \text { indiretos, manejados pelos setores privilegiados do meio rural". }
\end{aligned}
$$

Quanto ao setor florestal, a política de incentivos fiscais permitiu um forte impulso, uma vez adotada uma política de grandes subsídios para reflorestadoras que

\footnotetext{
${ }^{9}$ Revolução Verde foi o nome dado ao modelo de desenvolvimento agrícola, exportado pelos EUA depois da $2^{\mathrm{a}}$ Guerra, para vários países subdesenvolvidos. A "Revolução Verde" visava, principalmente, criar demanda por produtos industrializados, principalmente, insumos modernos: inseticidas, fungicidas, adubos químicos etc., máquinas, tratores e demais implementos, além de semente e propágulos melhorados.
} 
priorizassem áreas da fronteira, em especial na região amazônica. Lá surgiram imensos projetos como o Jari que, de tão grande, não conseguiu se firmar no Pará. Centenas de empresas agroflorestais em todo o norte e centro-oeste adquiriram grandes latifúndios, ou mesmo se apossaram de terras através da grilagem, expulsando antigos moradores e criando uma forte onda de violência no campo. Essas empresas muitas vezes nem se quer tinham seus títulos de posse da terra legalizados conforme afirma Jones citando Oldair Zanata (Folha de São Paulo, 22/07/96, Página: 2-2) "grande parte dos títulos (de propriedade) examinados não resistem a uma análise jurídica, pois não só apresentam filiação dominial imperfeita, como os dados que estabelecem, relativos à área, limites e confrontações, não correspondem à localização física dos imóveis a que se referem".

A década de 90, no Brasil, foi marcada por um acontecimento duplo, grandioso em tamanho e importância para o meio ambiente e a biodiversidade - a Conferência das Nações Unidas sobre o Meio Ambiente e Desenvolvimento, conhecida como Rio-92 e o Fórum Internacional de Organizações Não-Governamentais, evento paralelo nãooficial mas de grande envergadura e peso político pela quantidade de forças representativas dos movimentos social e ecológico presentes. Da Conferência saiu, como documento principal, a Agenda 21, documento assinado por mais de cem paises que se comprometem com um calendário de ações de defesa da qualidade do meio ambiente e da manutenção da biodiversidade.

Uma das questões mais importantes do acontecimento Rio-92 foi fornecer elementos para a construção, em diversos segmentos sociais, dos conceitos de 'preservação' e 'conservação' do meio ambiente. A Rio-92 passa a ser um divisor de águas, no Brasil, quanto à consciência ambiental. De lá para cá, percebe-se não só uma mudança no discurso, mas também em práticas há muito já consolidadas pelo próprio aparelho Estatal, como agente hegemônico.

No que diz respeito à questão florestal, percebe-se, por parte de várias empresas florestais, na região sul e sudeste, uma preocupação maior em manter ambientes naturais intercalados aos plantios homogêneos, criando corredores de fauna, investindo em projetos de recuperação destes ambientes naturais e da fauna nativa 
existente ou re-introduzida, em projetos de educação ambiental e de uso medicinal de essências nativas, como o programa desenvolvido pela Klabin (Lago, 1993); em desenvolvimento de controle integrado de pragas e doenças e uso de controle biológico em movimento contrário à prática anterior, que era de uso intenso de agrotóxicos poluentes realizados por pulverizações aéreas, embora essas ações ainda tenham caráter compensatório para outras ações destrutivas causadas por essas mesmas empresas.

Quanto à Mata Atlântica, dos 1,1 bilhão de $\mathrm{km}^{2}$ originais, restam apenas 98 milhões de $\mathrm{km}^{2}$ de florestas. Alí, percebe-se que o ritmo de desmatamento tem diminuído ano a ano, o que ainda não garante a sua preservação, mas já é um sinal de avanço e esperança. A expansão imobiliária principalmente no litoral norte do estado de São Paulo é o principal fator de pressão sobre a floresta. No Paraná, segundo o SOS Mata Atlântica, o desmatamento segue na razão de cinco campos de futebol por hora desde 1985. (Agostinho, 1996). Porém, o desestimulo das atividades agropecuárias em função das restrições legais quanto ao uso de áreas na Serra do Mar vem proporcionando, em alguns lugares, incremento na área de cobertura florestal. Segundo Torres (1996) a mata Atlântica voltou a crescer no litoral sul do Estado do Rio, ao contrário do que ocorre no resto do país.

Quanto à Amazônia, a preocupação se mantém crescente. O anúncio da existência de consórcios asiáticos interessados na exploração da madeira amplia a dúvida sobre as reais preocupações do governo brasileiro. Para Godinho (1996):

"o mais evidente impacto ambiental nos $4.005 .082 \mathrm{~km}^{2}$ da Amazônia é o resultado do desmatamento desordenado e das queimadas, práticas que têm como objetivo preparar terras para a agricultura e pecuária. Até o final dos anos 80 , haviam sido desmatados quase $400 \mathrm{mil} \mathrm{km}^{2}$ (cerca de $8 \%$ da área total da floresta). Atualmente, o ritmo anual está na casa dos 14 mil km"'.

No cotidiano, a política governamental tem deixado brechas perigosas a serem controladas por grupos interessados na expansão imobiliária (questões presentes em várias áreas ecologicamente sensíveis em quase todo o litoral brasileiro) ou no 
controle de áreas de interesse conservacionista como é o caso da discussão sobre o direito do empresário Antonio Ermírio de Morais de construir uma hidroelétrica em região do Vale do Ribeira (Ermírio, 1995).

Como se pode perceber, foram quase quinhentos anos na nossa história, além dos vários séculos na de nossos colonizadores europeus, considerando a floresta como empecilho ao desenvolvimento social e econômico. A floresta deveria ceder lugar aos campos agricultáveis e a árvore representava uma matéria prima a ser extraída da natureza.

Essa representação encontra-se alojada no imaginário social do povo brasileiro e, como se viu, sempre fez parte da ideologia dos dirigentes desta nação.

$O$ pensamento ambientalista que se contrapõe a essa visão apenas utilitarista do meio ambiente tem cerca de quarenta anos, ou seja, é muito recente, não fazendo, ainda, parte da cultura brasileira. É evidente que ações isoladas de conservação da natureza vêm acontecendo desde o século passado, mas de forma pontual, sem forjar esta perspectiva na cultura.

Hoje, com a atuação dos movimentos sociais e ambientalistas, com a presença dos temas relacionados à ecologia e ao meio ambiente na mídia, novos elementos vão se juntando no imaginário social que podem se traduzir em mudanças de atitudes nas diferentes camadas da sociedade brasileira.

\subsubsection{Produção do saber sobre a floresta e reforma agrária}

A reforma Agrária no Brasil vem sendo discutida e vivenciada por diferentes atores da política nacional desde a década de 50 . No início surge, através das Ligas Camponesas, no nordeste. Após o golpe militar de 1964 o general Castelo Branco assina o Estatuto da Terra, instrumento da ditadura militar que reconhece a necessidade de execução de uma política fundiária, traça diretrizes para a sua implementação, que, não saindo do papel, dá lugar a uma política de desenvolvimento industrial urbana que concentra a renda e a terra, além de promover intenso êxodo rural. Com o fim do regime militar ressurge com mais força a luta pela reforma agrária presente: no III Congresso 
dos Trabalhadores Rurais da CONTAG $^{10}$, realizado em Brasília em maio de 1981; no acampamento da 'Encruzilhada Natalino', em Ronda Alta em 1981; no acampamento Herval Seco em 1984, na Fazenda Anoni em outubro de 1985; nas amplas discussões sobre a função social da terra e no posterior retrocesso da Constituição de 1988, que não reconheceu a figura do latifúndio por dimensão já presente no Estatuto da Terra de 1965; nas reivindicações populares da década de 80; nas campanhas presidenciais de 1989 e 1994, em especial, na plataforma política de Luiz Inácio Lula da Silva e no Movimento dos Trabalhadores Rurais Sem-Terra, o MST, que desponta em 1984 e se expande até os dias de hoje. A ausência de uma resposta dos governos que se passaram desde 1950 fez emergir um movimento social autêntico de luta pela terra. Um novo perfil vem sendo traçado no campo brasileiro com as inúmeras ocupações que vêm ocorrendo desde 1984 sob a direção do MST em todo o Brasil.

Ocupar, Resistir e Produzir é o lema atual do MST.

'Ocupar' as terra improdutivas para distribuí-las para os que nela querem trabalhar. As ocupações têm provocado um movimento cidade/campo contrário às pressões impostas pelo modelo de desenvolvimento brasileiro.

'Resistir' se caracteriza tanto pela persistência dos acampados que permanecem vários anos, sob lonas, à beira de estradas ou dentro das fazendas, à espera da divisão da terra, quanto pela persistência do Movimento amplo de ocupação, que se expressa pelo número crescente de acampamentos e cadastramentos de sem-terra. Eles devem resistir à reação, sempre presente, seja dos latifundiários organizados e suas milícias, seja do aparelho de Estado que intervém de forma policialesca, controlando as ocupações muitas vezes com o uso da violência, como foi o caso de Eldorado de Carajás, no Pará. Essa reação das oligarquias rurais pode ser entendida, segundo Fernandes (1972, p.198) como:

"medo pânico desses setores diante da mudança social 'estrutural', 'rápida' ou supostamente 'incontrolável', (que) levou-os a neutralizar socialmente os tipos de modernização a que precisam recorrer e que

\footnotetext{
${ }^{10}$ CONTAG - Confederação dos Trabalhadores na Agricultura
} 
podem ser compatibilizados com o grau de 'racionalidade capitalista', que estão dispostos a fomentar."

'Produzir' passa geralmente por duas fases: uma inicial, durante o periodo de acampamento, quase sempre organizada de forma coletiva e voltada para a subsistência: arroz, feijão, milho, mandioca etc., às vezes voltada para a comercialização em mercados próximos, através de horticultura e fruticultura, por exemplo: abóbora, melancia etc. E uma outra fase, mais definitiva, que acontece após o reconhecimento do assentamento pelo Estado e a demarcação das glebas ou lotes. Neste momento, a organização interna se encaminha para formas individuais ou coletivas quanto ao uso da terra.

Os sistemas de produção nos assentamentos rurais variam de acordo com a região e, também, com o grau de organização desenvolvido ao longo do período de acampamento, mesclando formas tradicionais de agricultura familiar com baixo nível de utilização de insumos, até formas mais avançadas de organização associativa ou cooperativadas para a produção e/ou comercialização com o uso de tecnologias modernas.

Ao ocupar, resistir e produzir o MST está criando uma condição nova de vida para aqueles que dele participam.

Muitos dos trabalhadores que participam das ocupações organizadas pelo MST foram historicamente expropriados dos seus meios de produção e, num processo de urbanização, se vincularam, pelo menos em alguns momentos de suas existências, como trabalhadores nos setores industrial ou de serviços. Outros mantiveram-se sem vínculo empregatício, ou na economia informal. Tanto para os ex-camponeses que, por terem sidos expulsos da terra, estão retornando ao campo através da luta pela reforma agrária, quanto para os trabalhadores urbanos, cujas raízes agrárias já se encontram muito distantes, a luta pela posse da terra é um processo educativo de conquista da cidadania. Pessoas se organizam, se preparam e concretizam as ocupações e a vida comunitária exigida nas condições posteriores de resistência. Nesse processo, elas aprendem formas de convivio coletivo e maneiras próprias de resolução e superação dos inúmeros conflitos 
advindos da luta e das condições de sobrevivência. No acampamento, saberes sobre o cotidiano se coletivizam, formando uma rede de significações que se cruzam para interpretar as novas circunstâncias de vida e produzir, em especial, os conhecimentos sobre as formas de lidar com a natureza. Assim, o acampamento é um espaço rico em resignificações constantes; é, portanto, um 'locus' de intenso processo de educação comunitária.

Durante o momento de ocupação as questões mais emergentes ou prioritárias dizem respeito à manutenção do grupo no acampamento. Os trabalhos em equipe estão voltados para a construção das barracas de lona, a procura de água para a alimentação e higiene, a abertura de fossas, a busca de recursos e doações, os plantios iniciais, a segurança, a cozinha e a saúde. Há um grande desafio na relação direta com a natureza e entre os acampados.

Diversas questões referentes ao meio ambiente passam a fazer parte do cotidiano de um acampamento: a necessidade de derrubada de árvores para a construção dos barracos e os desmatamentos para os plantios; a utilização de maquinários (tratores e implementos) ou simplesmente o uso do fogo para o preparo das áreas iniciais de produção; a utilização das águas de córregos, lagoas ou poços; a presença do lixo; a caça de animais silvestres como fonte de proteínas para a alimentação.

Nos assentamentos definitivos modificam-se as condições originais, que ganham contornos diferentes e formas de lidar com o ambiente também diferentes. No momento da demarcação das terras separam-se os espaços de exploração, de reservas obrigatórias e legais e áreas comuns ou comunitárias; são construídas curvas de nível para a contenção da erosão; abrem-se estradas vicinais e, com muita luta, o Estado libera os recursos financeiros provenientes do PROCERA ${ }^{11}$. Esse novo contexto traz, com ele, obrigações, contrapartidas, informações, reflexões, decisões, ações, enfim, uma práxis que vai produzindo diferentes maneiras dos assentados construírem suas representações sobre o mundo. A práxis produz as representações e essas, dando forma ao mundo, 
conduzem os modos de agir sobre a natureza e os outros seres humanos. As experiências vividas produzem diferentes contextos sociais que se articulam na produção do cotidiano e tomam forma de representações sociais sobre esse cotidiano.

Interferem nesse contexto onde se produzem as representações e práticas sociais, as instituições governamentais que estão presentes nos assentamentos desde as primeiras negociaçães para a legalização das terras ocupadas. Elas têm como função implementar políticas públicas: educação, saúde, implantação de infra-estruturas construções e abertura de estradas, assistência técnica agronômica e creditícia, fiscalização etc.

$\mathrm{O}$ modelo agrícola disponibilizado pelo Estado é fortemente exigente em insumos modernos, agrotóxicos, fertilizantes químicos e mecanização pesada que, além de comprometer os sistemas biológicos naturais, causam a poluição do solo e das águas, doenças e enfermidades nos agricultores. É, ainda, pouco exigente em mão-de-obra, ou seja, não ocupa nem valoriza a disponibilidade de mão-de-obra familiar existente no assentamento. Constrói-se uma cultura rural voltada para padrões de desenvolvimento que interessam à reprodução do capital, em detrimento de modelos alternativos de produção que privilegiem a adubação orgânica, o plantio direto, o controle integrado de pragas e doenças e a mecanização com o uso da tração animal. A adoção de modelos alternativos permitiria, além dos ganhos com a produção, a proteção irrestrita do produtor e a conservação do meio ambiente.

Do ponto de vista do MST a tecnologia agrícola deveria propiciar tanto o aumento da produtividade do trabalho quanto das terras, mas com equilibrio do meio ambiente e a conservação dos recursos naturais. De acordo com o Programa de Reforma Agrária do MST (1995), deve-se "implementar pesquisas e técnicas agropecuárias que levem a um novo modelo adequado à realidade nacional e de desenvolvimento autosustentado".

\footnotetext{
${ }^{11}$ PROCERA - Linha oficial de crédito, específica para os pequenos produtores assentados pelo Programa Nacional de Reforma Agrária, aplicada durante os primeiros cinco anos em cada assentamento rural.
} 
Porém, ainda não houve tempo suficiente para o movimento organizar, na sua perspectiva de cooperativa, uma assistência técnica que possa direcionar os assentamentos nesse sentido desejado.

Participar do MST, em qualquer nível de militância, torna-se viver um intenso processo de aprendizagem sobre as formas de perceber e manejar o meio ambiente novo, com o qual acampados e assentados se defrontam. Representações anteriores servem de apoio para as novidades que surgem no novo contexto de vida. Elas ancoram o que parece pouco familiar às representações constituídas em situações já vividas. Complementam e superpõem interpretações com as informações que vêm dos técnicos, dos vizinhos, das lideranças do MST, dos visitantes, das universidades, dos 'apoios'12. Produzem novas representações a partir do que experimentam na prática cotidiana de trabalho e convívio comunitário. Constituem o espaço rural com formas específicas de intervir na natureza e são constituídos, também, pelas respostas que esta lhes oferece, traçando significações que dirigem as práticas e dão objetividade ao mundo.

\footnotetext{
12 "Apoios" são todas as pessoas, consideradas pelos assentados, que prestam algum tipo de serviço no assentamento ou, então, que fazem algum tipo de doação em dinheiro ou em espécie.
} 


\section{METODOLOGIA}

\subsection{O método}

O tipo de estudo realizado não se propôs a encontrar relações de causa e efeito. Os pressupostos teóricos da pesquisa remetem os dados empíricos ao contexto histórico mais amplo, onde estão inseridas as representações dos assentados. O processo anterior de urbanização a que se submeteram os assentados da Fazenda Ipanema, a necessidade constante de luta pela permanência na terra e as demais condições sócioeconômicas e culturais onde se insere a população objeto deste estudo, permitiu compreender as representações sobre a floresta dentro dessas determinações.

Este trabalho teve como referência a 'Teoria das Representações Sociais', do ponto de vista histórico-social, utilizada pela psicologia social. Essa teoria não se limita a ver o indivíduo como centro dos processos psicossociais, como na psicologia tradicional; não apenas se apoia na sociedade como forma de entender e explicar o indivíduo; tampouco considera que indivíduos e sociedade sejam a mesma coisa. Indivíduos e sociedade não se reduzem um ao outro, mas não existem um sem o outro. "Vidas individuais não são realidades abstraidas de um mundo social; pelo contrário, elas só tomam forma e se constróem em relação a uma realidade social" (Guareschi, 1994). Existe um movimento dialético entre indivíduos e sociedade. É impossivel querer entender questões específicas do sujeito como suas vontades, seus medos, seus mitos, suas lutas, sem compreender a relação desse indivíduo na sua prática social. A teoria das representações é a ferramenta que vai possibilitar conhecer como se processa a produção do saber sobre a floresta nesta pesquisa. Portanto, o método de análise só poderia ser dialético. 
Quando se deseja conhecer a representação de um determinado grupo, deve-se penetrar na realidade social deste grupo, que é o local onde se dá a construção da significação que é cognitiva e afetiva. Portanto, vai ser no cotidiano dos indivíduos, isto é, nas instituições das quais participa e, principalmente, no seu espaço produtivo, que acontecerá a troca de experiências e a produção das representações sociais. Como na citação de Guareschi (1994) “(..) (é)quando elas (as pessoas) estão expostas às instituições, aos meios de comunicação, aos mitos e à herança histórico-cultural de suas sociedades, que as Representações Sociais são formadas". No caso dos assentados da fazenda Ipanema as representações sociais se produziram tanto no processo de ocupação, como nas permanentes reflexões individuais e coletivas sobre a forma de organização para a produção nos sistemas utilizados no assentamento e nas práticas agrícolas adotadas.

Para se poder conhecer a produção do saber sobre a floresta pelos assentados na Fazenda Ipanema, foi preciso percorrer alguns caminhos que se complementaram à medida que, primeiro, o discurso foi explicitado e, por fim, o assentado, através da sua atividade, refletiu sobre o seu cotidiano. Foi nessa relação dialética de explicitação, ação e reflexão que se foi delineando o quadro que permitiu construir uma forma de compreensão sobre o papel da floresta para esta população em estudo.

\subsection{Procedimentos de coleta de dados}

\subsubsection{Instrumentos utilizados}

Dois instrumentos metodológicos da antropologia foram utilizados no levantamento de dados para se chegar às representações sociais: a história de vida e a observação participante.

A história de vida permite tanto a construção de uma documentação que se constitua num ponto de vista alternativo à historiografia oficial - é a "versão que os oprimidos e desprivilegiados têm dos grandes e pequenos acontecimentos" - quanto o 
estabelecimento de um diálogo entre informante e analista que pode desvendar novas dimensões da realidade e "pensar de maneira mais criativa a problemática que, através deles, nos propomos a analisar" (Debert, 1986, p.142).

A observação participante é uma forma de observação assistemática, onde as informações, as impressões, as idéias, os modos de pensar e agir do grupo social envolvido são percebidos em qualquer momento do cotidiano da relação estabelecida entre o pesquisador e os pesquisados, ou seja, sem hora marcada para acontecer. Segundo Selltiz (1987, p.79), na observação participante os pesquisadores (observadores) "se inserem na situação de pesquisa e na vida das pessoas que estudam. Embora as notas de campo e os relatórios de pesquisa usem nomes fictícios, os sujeitos da pesquisa não são anônimos para o observador participante”. Nesta pesquisa, foi acordado junto com os assentados, desde o início do processo, a forma de participação do pesquisador no espaço social da pesquisa e o nível de envolvimento nas questões concretas do cotidiano durante as fases exploratórias e de coleta de dados, ou seja, o pesquisador não se omitiu quanto às demandas por informações técnicas agro-florestais que lhe eram colocadas, apenas deixou claro aos assentados que durante o período inicial dos trabalhos de campo mais ouviria do que daria pareceres a fim de que pudesse entender com mais profundidade as questões objeto da pesquisa. Este método exigiu clareza do pesquisador quanto aos objetivos da pesquisa durante todo o processo, a fim de poder estabelecer o diálogo necessário.

As observações consideradas importantes para a pesquisa foram registradas em 'notas de campo' (Selltiz, op.cit., p.76), em uma caderneta pessoal.

Um instrumento metodológico da psicologia utilizado foi a técnica do desenho livre em sessões de dinâmica de grupos realizadas em diversos locais de concentração habitacional no assentamento. Foram feitas atividades de desenho a respeito do sonho da terra e a apresentação sobre a produção individual de cada participante para o grupo. Aplicado antes das entrevistas, esse procedimento serviu para se perceber, junto com o sonho, o projeto de produção global do assentamento, além da visualização de algumas representações da floresta pelos entrevistados. 


\subsubsection{Critérios de seleção da amostra}

\subsubsection{Primeiro critério - Referente à organização do assentamento}

Os assentados da Fazenda Ipanema estão hoje organizados em quatro associações:

- APROFI - Associação agroflorestal dos Produtores Rurais da Fazenda Ipanema, com 60 familias;

- ASPAR - Associação dos Pequenos Agricultores Rurais - com 40 famílias;

- Associação Filadélfia - com 40 famílias, e;

- Associação Nova Era - com 20 famílias.

Segundo Schuler (1995), a existência dessas divisões deveu-se às dificuldades quanto à adaptação das famílias ao processo de assentamento, que produziu divergências com a coordenação central da associação inicial, a APROFI. Essas dificuldades, segundo a autora, foram motivadas pelas condições sociais vividas pelas famílias durante o período do acampamento. Para Moitinho (op. cit., p.20) "estes movimentos de independência que alguns grupos realizaram estavam ocorrendo em todo o acampamento" e tinham suas raízes em "insatisfações que começaram a vir à tona" findo o risco de despejo.

A partir desta divisão, presumiu-se, no início da pesquisa, que foram produzidas diferenças de percepções entre os quatro grupos organizados e que existia um núcleo de afinidades em cada grupo, com projetos familiares e coletivos diferenciados entre eles. Portanto, para se perceber as representações sociais na sua dinâmica de construção, foi importante que estes grupos estivessem contemplados na amostragem.

Foi identificado quatro situações dos sujeitos em relação à organização interna do assentamento (Figura 2):

- Situação 1 - Sujeitos que participam das instâncias decisórias e que estão trabalhando em coletivos.

- Situação 2 - Sujeitos que não participam das instâncias decisórias e que estão trabalhando em coletivos. 
- Situação 3 - Sujeitos que não participam das instâncias decisórias (Associações e Conselho) e que estão trabalhando individualmente nos seus lotes (só a família).

- Situação 4 - Sujeitos que participam das instâncias decisórias e que estão trabalhando individualmente nos seus lotes.

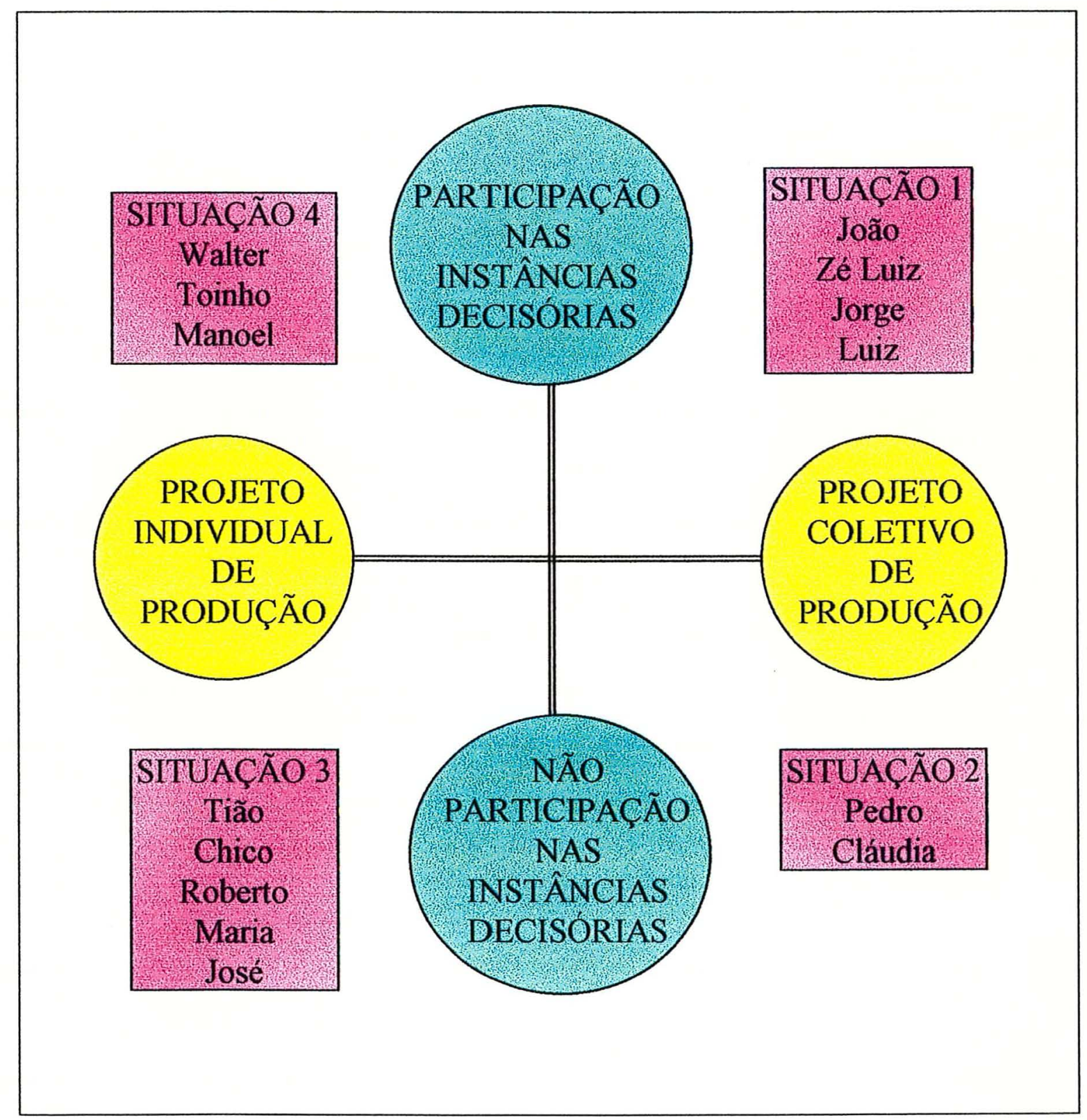

Figura 2: Quatro situações dos sujeitos em relação à organização interna do assentamento 


\subsubsection{Segundo critério - referente às áreas do assentamento}

$\mathrm{O}$ assentamento foi dividido pelo DAF/ITESP ${ }^{13}$ em áreas segundo o tipo de solo e as respectivas aptidões agrícolas: a Área 1, que começa próximo a Bacaetava e termina no Rio Ipanema, entre a Vila Smith e a Vila Marcilio Dias ${ }^{14}$ e a Área 2, que vai do Rio Ipanema até próximo à cidade de George Oetere ${ }^{15}$. Para efeito desta pesquisa partiu-se da premissa que os sujeitos construiriam diferentes projetos agropecuários em função da localização de seus lotes. Essa diferença de projetos definiria diferentes relações com a natureza $e$, portanto, propiciaria o surgimento de diferentes representações sobre o papel da floresta dentro de seus projetos.

A amostra selecionada para as entrevistas conteve sujeitos de ambas as áreas.

\subsubsection{Terceiro critério - referente às áreas de reservas}

Segundo o modelo de parcelamento dos lotes adotado pelo DAF/TTESP as áreas de reserva legal do assentamento ficaram contíguas e, de modo geral, margeando as áreas de reserva obrigatória, ou seja, próximas aos leitos dos córregos existentes.

Quanto a este último critério os sujeitos amostrais eram, necessariamente, vizinhos de áreas de reservas do assentamento, da área de floresta existente no ARAMAR ou das áreas da FLONA de Ipanema. Procurar-se-ia com isso, caracterizar as representações sobre a floresta a partir de sujeitos que conviviam em seus cotidianos com áreas de preservação.

Por isso, a amostra escolhida foi intencionalmente determinada encontrando-se todos os seus quatorze sujeitos nos três critérios acima mencionados.

\subsubsection{Fases da coleta de dados}

\footnotetext{
${ }^{13}$ DAF/TESP - Departamento de Assuntos Fundiários/Instituto de Terras do Estado de São Paulo

${ }^{14}$ A Área 1 engloba os moradores da Vila Smith e da Vila Cel. Mursa.

${ }^{15}$ A Área 2 engloba os moradores da Vila Marcílio Dias, das áreas próximas ao aeroporto e das áreas do Campos Realengos (antigo grupo 9).
} 
A primeira fase foi de apresentação do pesquisador e do estabelecimento de uma relação com o grupo social em questão. Esse período, que aconteceu nos meses de outubro e novembro de 1996, caracterizou-se pela presença constante do pesquisador no espaço social do grupo, participando de reuniões, festividades e demais eventos no assentamento. Paralelamente, foram realizadas visitas ao espaço familiar e estabelecimento de um diálogo individual com diferentes pessoas dos grupos. Essa etapa, considerada como exploratória, forneceu uma visão dos diversos aspectos do contexto atual do assentamento.

A segunda fase da pesquisa, que aconteceu entre novembro de 1996 e março de 1997, foram realizadas as cinco sessões de dinâmica de grupo em locais diferentes no assentamento: Área 2, no dia 09 de novembro de 1996, com 11 participantes; Vila Smith, no dia 23 de janeiro de 1997, com 16 participantes; Área 1, no dia 06 de fevereiro de 1997, com 17 participantes; Grupo 9, no dia 09 de março de 1997, com 15 participantes e; Vila Mursa, no dia 23 de março de 1997, com 16 participantes.

Essas reuniões tiveram, também, a função de apresentar formalmente, para o maior número possível de assentados, as intenções do pesquisador, os objetivos e desdobramentos da pesquisa. Essa dinâmica, além de produzir a socialização dos projetos pessoais, produziu um clima de entendimento e tranqüilidade quanto à presença do pesquisador e seus objetivos.

Todas as sessões de dinâmica de grupo (Figura 3) foram gravadas. As falas foram tabuladas em um quadro síntese que serviu para a definição do 'projeto atual de produção do assentamento', (Anexo A) 


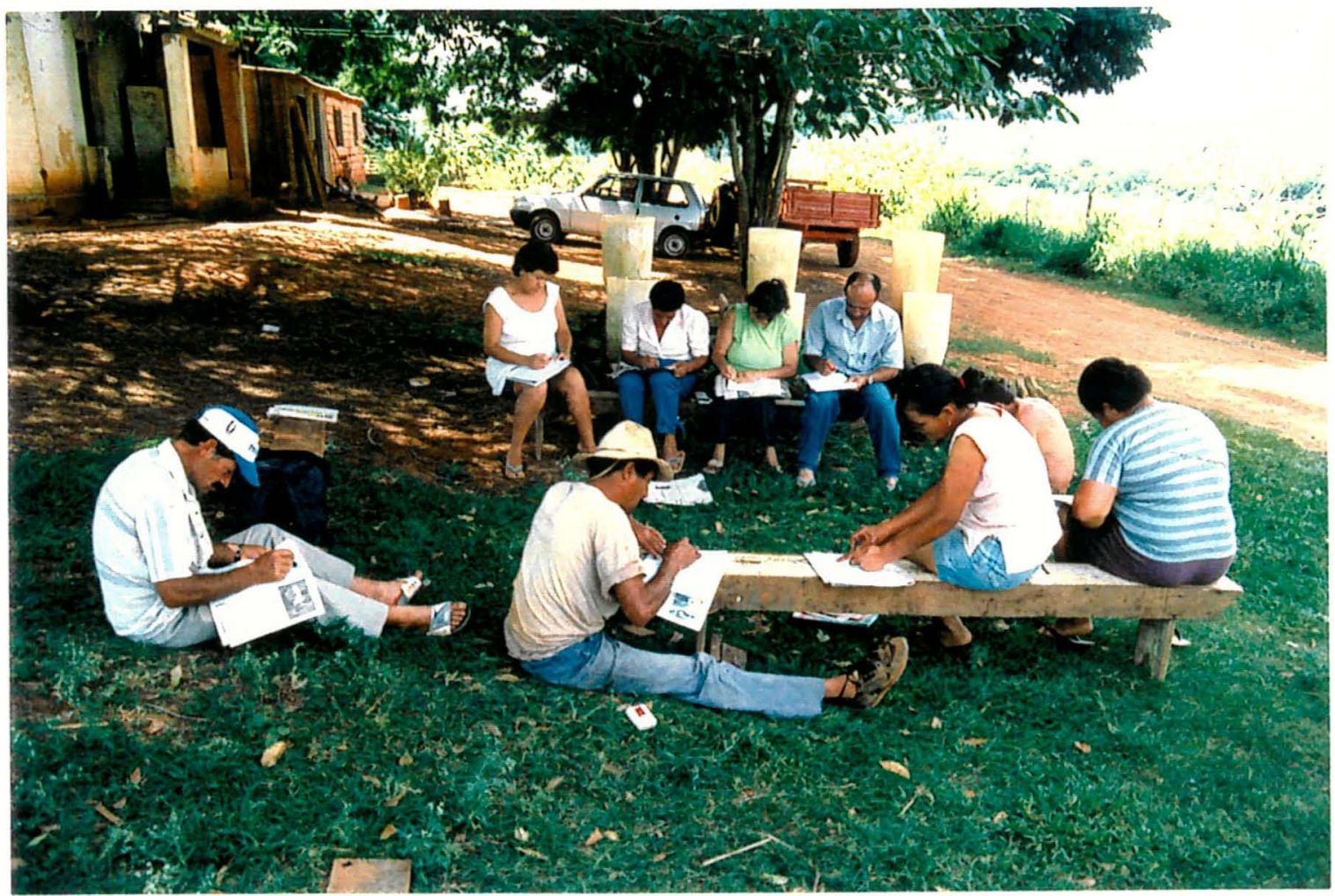

Figura 3: Sessão de dinâmica de grupo na Área 2

$\mathrm{Na}$ terceiro fase, entre novembro de 1996 e julho de 1997 foram realizadas entrevistas dirigidas e semi-estruturadas com 24 (vinte e quatro) assentados distribuídos entre os quatro grupos (associações de moradores). Dessas vinte e quatro entrevistas, após analisadas, foram escolhidos quatorze sujeitos significativos dentro dos critérios acima apresentadas, relacionadas à organização interna do assentamento (figura 2), à distribuição dentre as áreas 1 e 2 do assentamento e serem vizinhos às reservas, que compuseram a amostra final e que permitiram compreender a dinâmica de produção do saber sobre a floresta, juntamente com os outros procedimentos empregados na pesquisa $^{16}$.

Essas entrevistas levantaram a história das famílias, suas experiências anteriores em situações urbanas e rurais; processo de organização durante a ocupação da fazenda; os acontecimentos sociais (individuais e coletivos) mais marcantes nos quatro anos de assentamento; questões relativas à organização, produção e comercialização; expectativas atuais e futuras quanto ao projeto familiar no assentamento e, por fim,

\footnotetext{
${ }^{16}$ Serão atribuídos nomes fictícios aos autores das falas a fim de garantir o anonimato dos entrevistados. Os textos referentes às falas aparecerão sem aspas mas com um tipo de letra diferenciada (Arial 10) em relação ao restante do texto (Times New Roman 12).
} 
situações sobre relacionamentos com a floresta: necessidade de madeira; utilização de produtos e sub-produtos; experiências silviculturais; possíveis projetos na gleba; questões ambientais vivenciadas, além de outras questões do cotidiano.

As entrevistas foram realizadas no espaço familiar dos assentados selecionados para compor a amostra. Por isso, em algumas situações aparece a fala do cônjuge ou mesmo de algum familiar presente no momento da entrevista, que tenha feito algum comentário relevante. De qualquer forma, o critério fundamental adotado para a escolha do entrevistado foi a obrigatoriedade de ser cadastrado junto ao INCRA e que se apresentasse como responsável pelo lote. Além disso, outro quesito foi a obrigatoriedade de ser vizinho de reservas.

A amostra dos entrevistados foi, portanto, determinada pelos critérios: participação; distribuição geográfica dentro do assentamento ${ }^{17}$ - Áreas 1 e 2; e ser vizinho a uma reserva.

As entrevistas foram registradas com o auxílio de um gravador e seguiram um roteiro pré-definido (Anexo B)

\subsection{Procedimentos de análise dos dados}

Quanto ao método de tabulação e análise dos dados foram construídos diversos quadros (Anexo $C$ ) que agruparam as informações por temas específicos. Não houve preocupação em quantificar os dados das entrevistas uma vez que a importância central do trabalho foi a de perceber as conexões existentes entre as diferentes representações e os núcleos aglutinadores das representações.

Por tratar-se de uma pesquisa qualitativa, o mais importante não é mensurar relações de causalidade entre variáveis. $O$ essencial nesse tipo de investigação é conseguir penetrar nos diferentes contextos existentes e poder captar, tanto no discurso explícito quanto na prática social, o movimento dialético das construções individuais e coletivas.

\footnotetext{
${ }^{17}$ Para efeito desta pesquisa os moradores das Vilas Smith e Mursa foram considerados da Área 1. Os moradores do Grupo 9 foram agrupados com os moradores da Área 2.
} 
Para se encontrar os temas em torno dos quais apareceram conteúdos sobre a floresta nas histórias de vida e nos sonhos para o lote procedeu-se da seguinte forma:

Foram listadas 50 (cinqüenta) proposições que apareceram sobre a floresta e o elemento arbóreo (Anexo D) e, posteriormente, essas proposições foram classificadas dentro de temas comuns, em pranchas (Anexos F, G, H, I, J) que separavam os sujeitos pelas situações relacionadas à organização da comunidade. Assim, pôde-se tecer algumas considerações que se complementaram com dados da observação participante.

Os temas encontrados nesse tratamento dos discursos sob os quais se concentraram as representações, se referiram: à moradia, ao projeto agropecuário, à preservação, às reservas e aos animais silvestres.

As pranchas ofereceram o cenário onde surgiram os temas, no que se refere à posição dos sujeitos nas situações de participação (Figura 2) consideradas pela pesquisa.

Voltando-se aos textos dos sujeitos onde se inseriram as afirmativas encontradas dentro de cada tema, pôde-se descobrir as conexões que os sujeitos faziam entre um assunto e outro, confrontando essas conexões internas a cada discurso, com a prática dos sujeitos. Os desenhos e as falas por eles explicados nas dinâmicas de grupo permitiram traçar um quadro indicativo das prioridades de cada sujeito. Esta técnica pode ser considerada como uma 'triangulação' (Minayo, 1996).

Posteriormente, a articulação dos significados da floresta surgidos no grupo dentro do contexto sócio-histórico, permitiu uma compreeção sobre o movimento de produção do saber sobre a floresta 


\section{RESULTADOS E DISCUSSÃO}

\subsection{O contexto de produção das representações sobre a floresta}

Neste bloco foram utilizados trechos significativos das falas dos entrevistados que agrupados em seqüência lógica permitiram reescrever, sob seus próprios pontos de vista, os diferentes contextos que formaram a história dos assentados da Fazenda Ipanema. Esta história está sendo apresentada com o seguinte encadeamento diacrônico:

- As histórias dos sujeitos antes da ocupação.

- A formação do grupo social.

- A consolidação do grupo social.

\subsubsection{Os sujeitos antes da ocupação}

José viveu sua vida inteira como pequeno agricultor no interior da Bahia, tendo vindo para Piracicaba apenas quatro anos antes da ocupação, segundo ele, atraído pela fama do estado de São Paulo como um lugar para se ganhar dinheiro. Chico, trabalhou por dezesseis anos em Santa Bárbara, SP, ligado à tecelagem. Roberto, apesar de ter sido agricultor, viveu muitos anos nas cidades de Americana e Santa Bárbara, trabalhando como servente, ambulante, e, por fim, como turmeiro, conduzindo bóias frias para o corte de cana na Usina Santa Bárbara, em Americana, SP. Maria, agricultora de origem, foi nascida e criada na Bahia tendo vindo para Campinas há apenas 8 anos atrás, trabalhando como doméstica em casa de família, e seu esposo como ajudante de pedreiro. Tião, saiu do Paraná com aproximadamente vinte anos e veio para a cidade de Itapetininga, no estado de São Paulo, para trabalhar como motoserrista, no corte de 
eucalipto, porém, terminou como cobrador numa empresa municipal de transporte coletivo. Toinho, tendo trabalhado dezessete ou dezoito anos na lavoura, teve uma experiência fabril por três anos em São Paulo, trabalhou em um supermercado na capital, São Paulo, e depois, ficou em Piracicaba por mais cinco anos, trabalhando na Usina Costa Pinto, até sua demissão, causada por envolvimento em questões políticas no interior da Usina. João tem origens rurais, mas foi criado na cidade, tendo experiências profissionais em diversas atividades na indústria. Pedro trabalhou em São Paulo e Santos, mas passou a maior parte da sua vida em Muzambinho, Minas Gerais, trabalhando na roça e em diversos outros serviços eventuais.

Pôde-se observar que algumas situações foram comuns à maioria dos entrevistados: o desemprego ou sub-emprego no período anterior à ocupação; dificuldades sociais e econômicas que permeavam a vida de todos; a falta de perspectiva por uma vida mais segura e estável na cidade grande; a origem camponesa, com períodos mais ou menos longos de experiência urbana; e o sonho de voltar para a terra, ter uma casa e um lote onde plantar.

Os entrevistados não declararam terem sido proprietários de terra, com exceção de José, que possuía um terreno na Bahia, mas cuidaram de sítios, arrendaram terra ou trabalharam como bóia-fria em algum momento de suas vidas.

Quando indagados a respeito da origem agrícola, todos manifestaram ter raízes no campo, mesmo que apenas na infância como nos relatos de João e de Walter exemplificando abaixo:

Meu pai, minha mãe, até os (meus) cinco anos mais ou menos de idade, trabalhavam na roça mesmo, lavoura mesmo. (João)

Eu ficava lá, enquanto eles trabalhava eu ficava lá, brincando lá... debaixo do... do... das árvores, aguardando até as horas de trabalho deles, depois a gente vinha prá casa. aí depois quando eu atingi já uma idade aí... 5 ou 6 anos, que já dava prá fazer uma coisinha eu comecei a fazer...não é?" (Walter)

Sobre os motivos que os levaram a trocar a roça pela cidade ficam explícitas as dificuldades e os fracassos vividos pelas famílias dos entrevistados. Os 
depoimentos mostram os problemas que o trabalhador rural tem enfrentado, em particular no estado de São Paulo, cujas razões encontram-se nas sucessivas crises agrícolas desde a década de 50, provocando o êxodo rural de pequenos produtores rurais e o assalariamento como bóia-fria, como nos indicam os estudos de D'incao e Mello (1976), Ianni (1984). Os assentados expressam esse contexto em diversos momentos:

Eu saí de lá devido as coisa lá táva muito fraca...recursos, a gente prá sobreviver era mais difícil...não é? (José) (saiu da Bahia aproximadamente em 1989)

Meu pai deu um tipo dum... dumas coisa nele que ninguém entende. Ele sumiu pru norte e largou a minha mãe falando sozinha...não é? Ficou difícil e aí ela começou a tocá de trabalhar com os filhos.... (Chico)

...a gente não tinha profissão, não tinha leitura, não tinha nada...não é? (Roberto)

...só que o ganho da roça não dava prá nós vivê. Aí nós veio da Bahia prá cá... prá vê se melhorava mais um pouco de vida. (Maria)

Trabalhava e cultivava uma terra e o cara pedia a terra depois... aí viemos trabalhar de empregado...não é? (Tião) (declarou ter saído da terra por volta de 1989).

...lá não tinham mais condições de trabalho (a família). Começou a faltar serviço lá na lavoura e São Paulo tava oferecendo melhores chances de trabalho...foi todo mundo embora...foi em 55 (1955), mais ou menos... (Walter)

Era o lugar dos barãos mesmo...não é? Lugar muito forte... o café lá... depois começou a a fracassar...tantos conhecidos nossos também foram embora prá São Paulo também. Não tinha mercado de trabalho pro trabalhador rural não. (Walter)

As dificuldades na vida urbana e o sonho de voltar para a terra aparecem, também, em diferentes recortes de suas histórias de vida:

Fiz um pouco de tudo na cidade... só que o ideal mesmo, o objetivo ideal era sempre conseguir um pedaço de terra. Esse era o sonho. Parece que táva já na raiz mesmo. (João) 
...o único jeito, a única solução que eu achei que ia melhorar a minha solução foi ter enfrentado esta luta da reforma agrária, prá ver se me ajudava é que eu podia, ao menos ter o que eu perdi, lá na Bahia, o retorno de volta. Ao menos um pedaço de terra prá mim trabalhar. (José)

Grande parte do pessoal que veio táva desempregado. Os caras tinham que vir mesmo prá não morrer de fome lá na cidade, mudar a vida dele aqui mesmo. (João)

Cidade é duro prá viver com 6 filhos Daí é que me deu na cabeça e eu disse, sabe que eu vou mesmo... (Manoel)

Na época que o Movimento dos Sem-Terra passou por lá, a vida tava um pouquinho difícil...não é? Táva difícil, táva desempregado...não é? Um pra lá, outro prá cá... (Chico)

O sonho do retorno ao campo se misturava às condições objetivas da vida na cidade - fome, desemprego, problemas de moradia - e às condições subjetivas desesperança, angústia, medo - em que a maioria estava imersa. Para alguns, a volta à terra significava uma possibilidade de superação dessas dificuldades e a chance de reconstrução de uma vida digna, onde, no mínimo, pudesse haver a produção do alimento necessário para a subsistência e a possibilidade de terem uma moradia decente. Porém, o sonho do retorno à terra trás, também, um pouco das raizes camponesas e de um certo saudosismo de uma infância perdida. Portanto, o sonho da volta ao campo busca seus elementos figurativos na fantasia infantil, porque a realidade presente naquele momento estava marcada pela expropriação e exclusão social.

O Movimento dos Trabalhadores Rurais Sem Terra - MST aparece no momento de crise intensa na vida desses sujeitos, fazendo emergir os elementos saudáveis da infância perdida, do campo distante, que aparece como possibilidade de vencer as agruras do momento presente. É portanto a imagem do campo como salvação, como esperança, que todos os entrevistados denotaram ter levado para a ocupação, junto aos seus parcos pertences. Essa imagem apareceu tanto nas falas sobre os sonhos como nos desenhos solicitados a eles. 


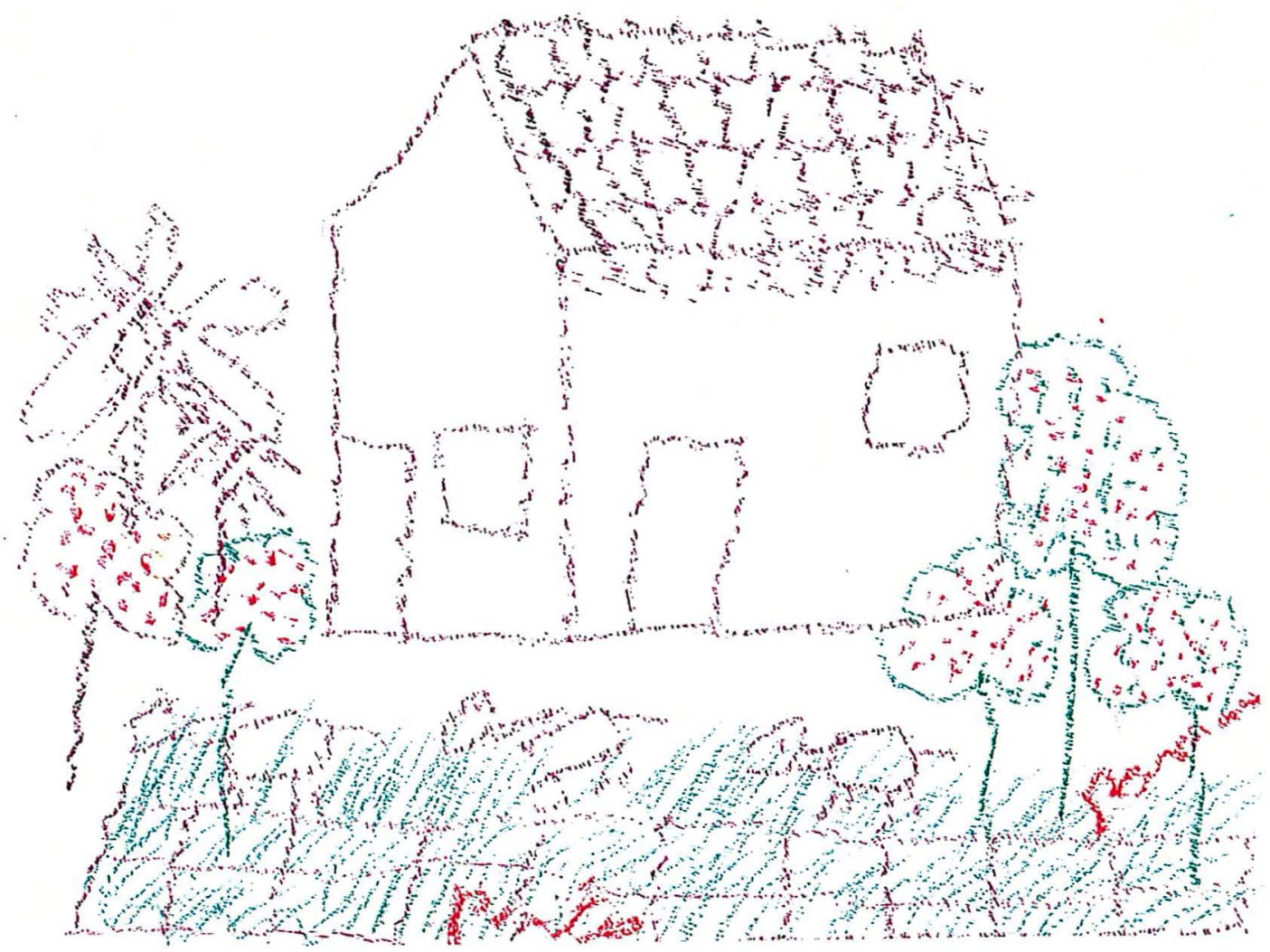

Eu penso em mexer com criação... uma casa com pomar... Fazer com que a gente compre o menos possivel

Figura 4: Desenho feito por assentada representando o sonho da volta ao campo.

É que nós tinha vontade mesmo de... voltar a lavoura, agricultura e nós vimos que essa seria a última... o único meio, não tinha outro meio...não é? (Walter)

A gente tem...somos nascido e criado em cima da terra, então você pode tá em qualquer lugar que você sente aquela vontade de voltar prá terra...não é? E o qual a gente hoje tá aí, esperando que,... se realizado daqui prá frente, cada vez mais...não é? A respeito da terra. (Toinho)

\subsubsection{Formação do grupo social: a ocupação e o acampamento}

- A preparação para ocupar 
A preparação para a ocupação da Fazenda Ipanema se deu através da Frente de Massas do Movimento dos Trabalhadores Rurais Sem-Terra. Segundo Fernandes (p.157, 1996), o processo de articulação e preparação do grupo que ocuparia no dia 16 de maio de 1992 a Fazenda Ipanema, durou cerca de nove meses e reuniu pessoas de quinze municípios paulistas: Iperó, Sorocaba, Itu, Tietê, Porto Feliz, Tambaú, Piracicaba, Leme, Limeira, Santa Bárbara D’Oeste, Sumaré, Campinas, Indaiatuba, Americana e São Paulo.

Algumas falas dos entrevistados nos mostra o clima de expectativa surgido após o contato com os militantes ${ }^{18}$.

...um companheiro meu que era da Bahia, táva lá em casa, ai ele chegou e falou... eu vim the fazer um convite aqui, duma coisa que eu tive a notícia hoje. É que chegou lá uns companheiros lá no meu barraco me convidando prá uma ocupação de terra da reforma agrária...não é? Ai eu vim the convidá se você se interessa a infrentá... (José)

...e na igreja tinha uns dias de encontro com as pessoas...não é? Aí a gente trocava idéia, um vizinho falava: ô, puxa...é a chance que a gente tem de conseguir um pedacinho de terra prá viver melhor do que essa vida na cidade e tal.... (Roberto)

$\mathrm{O}$ número de reuniões era muito variável de cidade para cidade. Houve casos de apenas uma reunião preparatória, segundo alguns relatos. Em outra situação, foram realizadas várias reuniões mas o número de participantes flutuava de uma para outra, não sendo possivel para os militantes a aplicação de uma metodologia contínua e crescente quanto aos conteúdos e informações. O resultado disso foi uma apropriação muito diferenciada dessas informações, gerando expectativas diferentes entre as pessoas e até desconfiança quanto à veracidade da proposta.

Não foi tão dificultoso. Só... só nasceu uma sensação dentro da gente. Prá onde esse pessoal tá levando a gente...não é?... Será que ele tão levando

\footnotetext{
${ }^{18}$ Militantes são os membros do MST que atuam na 'Frente de massas', ou seja, os militantes que organizam as ocupações nas regiões e municípios. São os que fazem o trabalho de base. No acampamento são os líderes que mantém vínculo direto com o Movimento. São o elo de ligação entre a direção regional ou estadual e a base.
} 
nós prá esse lugar mesmo ou tá levando nós prô Mato Grosso a fora? Igual a negada falava que pegava o pessoal e levava prum lugar e depois fazia os caras trabalhar de escravos.... ninguém pode saber o lugar que vai, ninguém pode saber nada...Será que essas pessoas tá levando a gente no lugar certo? É... então nascia um monte de dúvidas. Mas... foi indo, foi indo e cheguemos... (Chico)

Eu esqueci o nome dos que foram lá em Campinas (os militantes). então, chegou lá, fez uma reunião com o povo e diz que táva precisando de um povo prá fazer uma ocupação, com a terra... Entendeu? Uma certa reforma agrária. Mas nós não sabia o que é isso... Entendeu? Aí eu vim. (Maria)

Alguns passaram a ver todo esse processo como uma mágica onde, a partir de um dado momento e sob uma mão invisível, a terra cairia do céu, pronta, acabada, com tratores e toda a infra-estrutura necessária. Estes não conseguiram se ver como sujeitos da ação.

...quando nós saímos prá cá ninguém contou essas merdas nenhuma, nós vamos andando e só te falá coisa boa... em seis mês a gente tá assim, vamos supor, no causo, eu voces, mais outro trabalhador, nós tinha até... eu ouvi direito, de um trator. Peraí... pr'um homem trabalhador dentro de seis mês... se êle já tá com um trator na mão, quero ver se êle não vai prá frente? Negócio de... de... de comida... diz comida vocês só leva só prá... prá 8 dias. comida lá tem a vontade, pode ficar sussegado (Manoel)

Outros não se aperceberam das dificuldades que iriam encontrar durante a ocupação. Talvez por isso, um número muito grande de pessoas tenha desistido após a ocupação. A falta de experiências coletivas entre as pessoas que participavam das reuniões, gerou dúvidas e medos quanto aos reais objetivos dos militantes. Várias idéias e sentimentos foram sendo produzidas ao longo das discussões sobre a possibilidade do acesso à terra, a preparação da ocupação, a perspectiva de um trabalho coletivo, a relação direta com a natureza, a utilização de tecnologias modernas e várias outras.

Não havia, antes, uma experiência de construção coletiva, por isso, para muitos assentados, as reuniões de preparação para a ocupação foram as primeiras experiências de organização autogerida. Com a ocupação, o trabalho coletivo passa a 
tomar uma nova forma, que será analisada mais à frente. $\mathrm{O}$ início do assentamento será, por excelência, um momento de produção coletiva não só da existência material como de um saber sobre ela.

De acordo com os relatos, fica bastante claro que a preparação se deu mais no sentido de esclarecimentos sobre o MST, o cadastramento de pessoal, e, também, os informes sobre o processo da ocupação (relação e quantidade de materiais necessários), o que parece ter limitado a construção coletiva anterior à ocupação. Eles disseram:

Quando chegou as 7 horas, já bastante gente reunida, aí chegaram os militante...não é? aí começou a passar os informes prá gente. Como é que era a ocupação... qual era o problema do Movimento, o problema da reforma agrária... A luta pela terra, a gente subemos direitinho... eu gostei da conversa do militante e achei que era muito importante. (José)

Já inscrivia e já fazia o cadastramento naquela hora prá saber a quantidade de pessoas que vinha prá fazer a ocupação. Certeza nessa época arrumemos parece, duas mil pessoas prá fazer a ocupação na Fazenda Ipanema. Aí eu vim. (José)

...fizemos várias reuniões, acho que foi um mês, mais ou menos, onde preparava o pessoal, tentava informar como seria mais ou menos. $E$ a gente ficou na expectativa. Um dia ele marcou a saída e a gente veio se encontrar no assentamento. (João)

O pessoal aí na base ia colocando pro pessoal: quem pudesse tá juntando, comprando lona, ferramenta, ir se preparando, se estruturando... enxada....no final conseguimos arrecadar dinheiro prá pagar o ônibus... parte do dinheiro que sobrasse ficaria aplicado para distribuição da lona. (João)

Olha, a gente se informou mesmo, foi aqui. A gente foi convidado a vim e viemos. (esposa do Walter)

Eles davam instrução prá gente... o modo que a gente tinha que se preparar para o acampamento...não é?... Que de início ia ser dificuldade...ia ser complicado mas eles iam dar o apoio prá gente que merecesse... Agora,... sobre o alimento... eles iam dar esse apoio prá nós. (Roberto) 
Teve cidades que teve um trabalho até mais de 5 meses não sabe? Como Campinas mesmo foi quase 1 ano preparando...não é? Reuniões em bairro, outra coisa e outra...Piracicaba foi 3 meses de preparatória...não é? na qual a gente conseguimos se organizar 65 familias prá tá vindo prá cá na época. (Toinho)

A fala do Toinho, traduziu a forma de participação das mais atuantes (da base, como eles falam) na preparação para ocupar a terra.

Negociei ... os transporte, as lonas, 1500 metro de lona...não é? que era o equivalente para cobrir mais de 200 barracos se fosse possível... Tenho tudo, os relatório disso tudo em casa guardado, notas de compras, essas coisas tudo...dinheiro na época (de doações) prá nós tá vindo com esse pessoal...não é? 2 pau e meio na época e chegamos aqui, dia 16 de maio às 3 e meia da manhã, (Toinho)

- A ocupação e o acampamento

Na hora que nós cheguemos na porteira foi uma emoção muito grande, num sabe? Os militantes desceu, os militantes do Movimento dos Sem-Terra desceu e quebrou o cadeado...É... foi pacífico, sem atrito, sem nada. A fazenda realmente táva abandonada.

Nós táva procurando um lugar prá acampar, mas táva procurando um lugar que tinha água...não é? Foi indo, foi indo e cheguemos naquela área ali em cima, tinha água, tinha tudo, aí nós se acomodemos por ali. (Chico)

$\mathrm{O}$ ato de quebrar o cadeado foi cheio de significações. "Foi uma emoção muito grande" - essa expressão sintetiza o valor daquele momento para todos os participantes. $\mathrm{O}$ ato foi creditado à liderança, porém, foi compartilhado por cerca de três mil pessoas presentes. Esse ato de "quebrar o cadeado" e "abrir a porteira" vai aparecer várias vezes em outros discursos, sempre simbolizando a conquista da terra.

No texto seguinte, aparece outra expressão que encerra o veredicto final: "tinha água, tinha tudo", ou seja, eis a terra. O que orientou a procura do local para o grupo acampar foi a presença da água. Depois vieram os preparativos para a construção dos primeiros abrigos para as familias: 
A direção que tinha, do estado, na época, do nosso Movimento, decidiu a área que ia ser feito o...implantado os barracos...não é? Pediu que ficaria... todo mundo construísse assim de uma forma... de um loteamento...não é? vamos supor de 5 em 5 metro um barraco, prá não ter problema de fogo, e...sempre deixando uma rua no meio, prá ter acesso...não é? Se precisa de ter um acesso rápido num barraco, uma doença, um socorro, outro, tá Ali. Então o pessoal seguiu essas linhas e...a hora que o dia amanheceu cada um pegou suas ferramentas e foi tirar madeira...não é? No mato. (Toinho) ...quando amanheceu o dia... não nós vamos ficar por aqui mesmo... cada um escolhe um lugarzinho que acha que é suficiente para o barraquinho.. (Roberto)

...um barraco prá cada família....850, quando chegou. (Manoel)

O ambiente florestal, a escolha e retirada das madeiras para a montagem do acampamento, além do processo de construção dos barracos pode ser bem compreendido através dos próximos relatos. A fala abaixo define a estratégia utilizada pela militância:

...tinha uma área de... uma mata...não é? uma área de mata lá no acampamento, então, os próprios militantes falou, o único jeito que tem é a gente usar essa madeira mais fina, essa madeira mais fraca, que não tem prestígio lá prá... prá alguma coisa e usar prá fazer barraco...não é? (José)

Houve uma orientação por parte dos militantes, tanto na fase de preparação da ocupação quanto no acampamento, para que não houvesse a depredação de ambientes florestais vizinhos à área ocupada.

...Oh... vocês não pode mexer aqui. E nós ia tirando aqueles paus prá fazer barraco e a mata nós deixava. $E$ aí, eles foram orientando a gente e a gente foi pegando o jeito deles. (Maria)

Se por exemplo... se mexesse nessas áreas que era cheia, por exemplo, se pegasse e arrancasse coqueiro prá tirar palmito, se pegasse era expulso do acampamento.... Porque era preservação...não é? Preservação do Meio Ambiente... (Chico)

Uma vegetação bastante utilizada na montagem da estrutura das paredes e teto dos barracos foi o bambu ou taquara, que havia em boa quantidade nas áreas 
próximas ao acampamento, beirando as matas. A esse tipo de vegetação não havia nenhuma restrição quanto à sua retirada pois, a ele, não era atribuído nenhum valor especial.

Inclusive alí na... passando a área 1 , não tem aquela volta? Não tem aquela mata ali? Ali tinha uma mata alí prá baixo que tinha muito bambu, sabe? Naquela noite, cedo... até o meio-dia mesmo, aquela moita de bambu acabou, sabe? o que era de bambu que saia dalí, não era brincadeira... (Tião)

É o que a gente mais utilizou de... prá barraco foi bambu. As travessas, as linhas, coisa e tal, os esteios não... eram madeira mesmo...não é? (Roberto)

No texto seguinte, do Manoel, ele aponta as principais madeiras que foram usadas, junto com o bambu, para a confecção das estruturas dos barracos:

O mais era 'araruva', que a 'espeteira' era algum que tinha, era a madeira que nós tirava...no chão ela (a araruva) com 6 meses estoura. Umidece... trepado assim, dura anos... Tinha lá em cima na serra (madeira de lei), mas outro chegou a derrubar um pau dessa grossura, pau nas costas... (Manoel)

Nessa última frase, ele está se referindo a alguém que teria desrespeitado as ordens vigentes e teria derrubado, lá na serra, uma árvore de lei e que, por isso, foi imediatamente punido pela coordenação.

Para cobrir e revestir as habitações não utilizaram materiais da natureza, como palhas, barro etc., e sim, lonas plásticas e pedaços de caixas de papelão metalizado (tetra brik). 


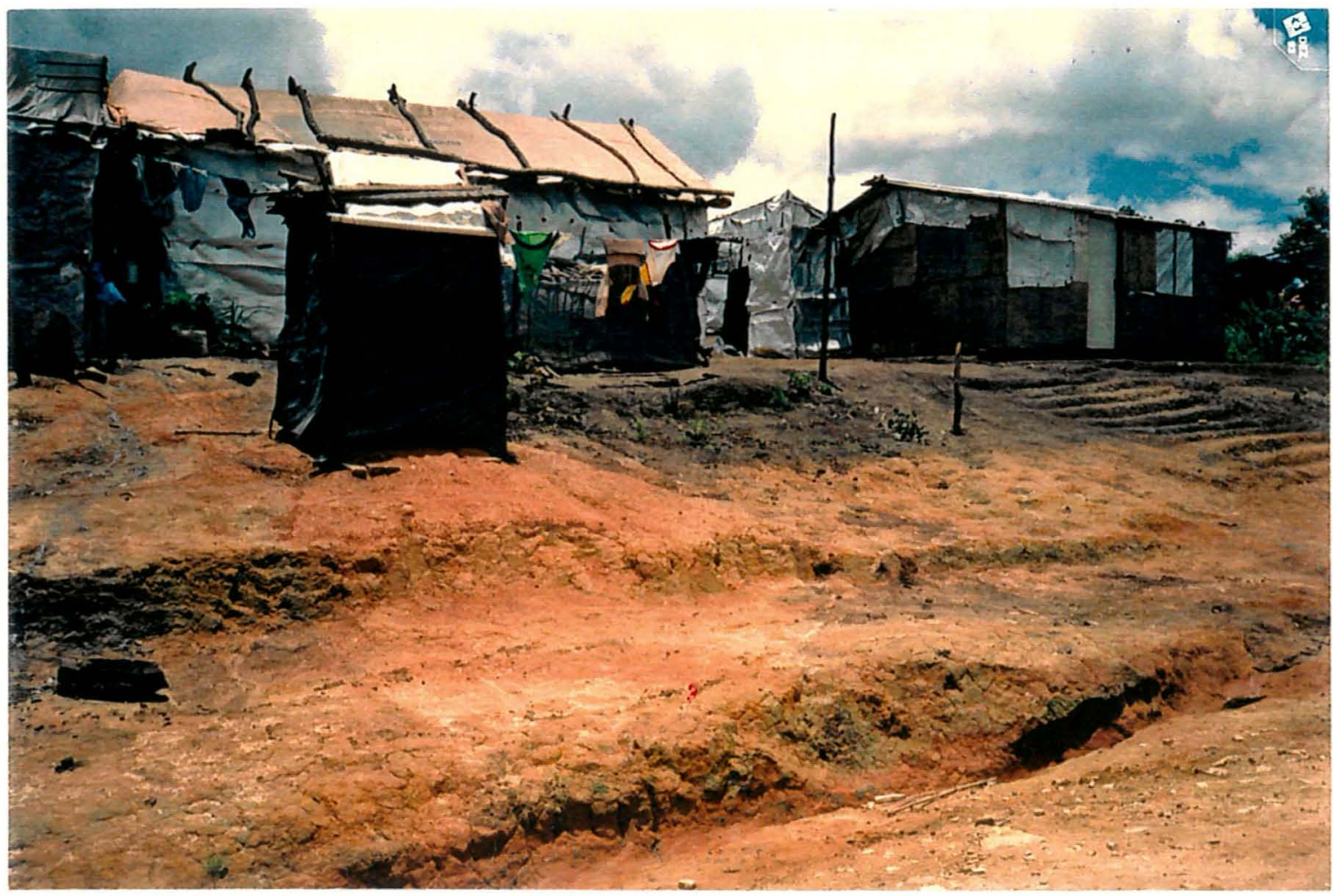

foto de Mercedes Capote

Figura 5: Detalhe das habitações cobertas com plástico e caixas de papelão.

É desse jeito, só não coberto de telha...não é? que era coberto com lona (Manoel - se referindo a atual moradia em que ele ainda hoje vive).

Aí a gente ganhava as lonas, das entidades. (Walter)

Eles forneceram lona no caso, quando a gente tinha dificuldade, que não conseguia comprar lona... (Roberto)

A pessoa às vezes rasgava a lona, dava um vento, que isso aí acontecia demais... Então a gente ia lá, conversava com eles e arrumavam uma lona prá gente. 


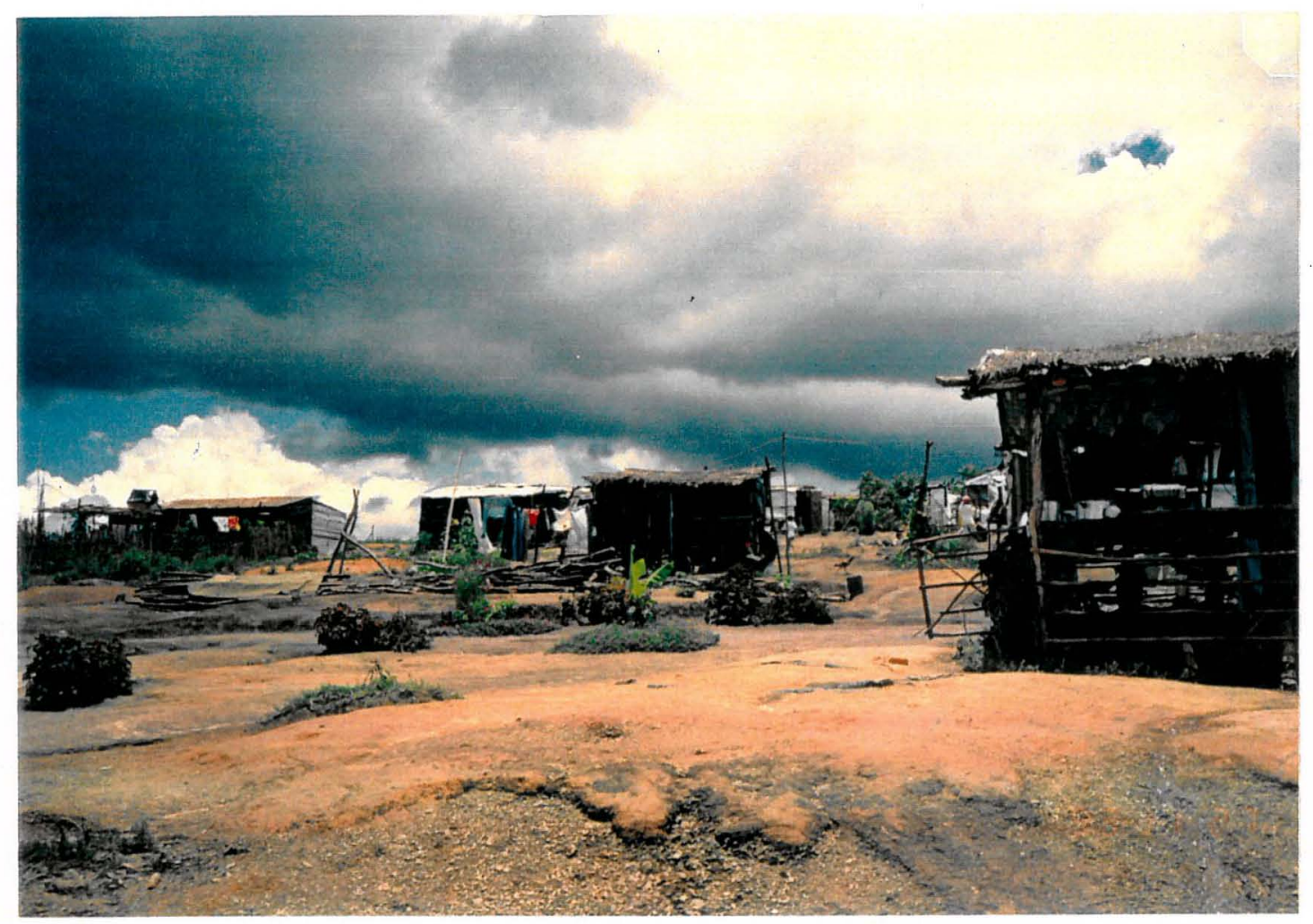

Figura 6: Detalhe de habitações no período do acampamento.

foto de Mercedes Capote

Enquanto contam sobre a construção das moradias vão dizendo sobre todas as novas relações que começaram a estabelecer naquele lugar conquistado - com a natureza, com as instituições locais, com o MST e com cada um do grupo constituído.

Contam que já na construção dos barracos aparece a necessidade de se constituir equipes de ajuda mútua:

Cada um fazia o seu, por conta própria.... De início não teve não (equipe), porque a gente chegou de madrugada, então aí cada um teve que se deslocar, catar um jeito de fazer o barraquinho dele e aí, praticamente, a equipe não deu conta de fazer o barraco todo prá todo mundo. (Roberto) 
Daí prá frente, aí, como era muita gente foi montada uma equipe específica...não é? prá construções de barraco. Que atendia todos...não é? Tinha uma equipe especifica prá isto. . Era uma equipe de $16 \ldots$ é... 16 companheiros... o serviço deles no assentamento era esse... era construir barraco para quem não tinha ainda, sabe? porque tavam morando com parente, muito apertado, e precisava de fazer o barraco...então... tinha essa equipe prá isso. Prá construções de barracos. (Toinho)

Se a pessoa não soubesse fazer barraco...não é? Aí tinha um responsável... tinha uma equipe de barraco e aquelas pessoas eram responsáveis de ajudar essas pessoas que não sabia fazer barraco...não é? Agora os que sabia, não...Os que sabia buscava pau, tá, tá... ia fazendo os barracos e num estante táva feito... Agora os que não sabia esse pessoal ia lá e dava uma força. (Chico)

As dificuldades foram muitas: chuva, frio, ventania, lama, falta de água, falta de comida, a polícia atrás da cerca, cai o barraco, constrói o barraco, sai o despejo, não sai o despejo e, de tanta improvisação, vinte barracos pegaram fogo, felizmente sem vítimas fatais.

Assim na semana que nós cheguemos fizemos uns barraquinhos lá e a coisa caia com o vento e aquela coisa. toda... Nós sofremos, viu!...foi 4 mês de sofrimento... Que a gente vai despejado... quase que nós não dormia. Cada um debaixo de um barraquinho de lona, mosquito... foi uma época de temporal e chuva igual a esses tempos... (José)

Barraco era que nem um geleia dava um vento e ficava balançando. (Manoel)

...queimava... muito fogo nos barracos... os barracos muito emboladinhos. Quem era acostumado na cidade não tava nem aí, agora num barraco de lona, outros com palha de sapé, de roda, mulecada traquina. Fogo...pronto!...Foi queimado uma média de uns 20 barracos. (Manoel)

Nesta última fala percebe-se uma representação da vida na cidade muito interessante, por parte de um assentado que possui fortes raizes campesinas e pouca adaptação nas situações do cotidiano da periferia de grandes centros urbanos. Ele considera que as pessoas que vieram das periferias seriam mais adaptadas a viver nas 
condições do acampamento do que um camponês que, apesar das suas dificuldades, não se via num barraco coberto de lona e nem vivendo 'emboladinhos' como numa favela. Esta fala é, ainda, muito rica em significações e movimento pois a forma de narrativa e expressão utilizada pelo Manoel, nos dá a perfeita idéia do cotidiano entre os barracos. No próximo texto, de Walter, alguém que morou mais tempo em periferia, já se evidencia outra preocupação, típica da cidade grande, o medo da violência.

Nós já morávamos na periferia e nós viamos isso tudo aí como um grande favelão ...não é? Até o nosso medo... Puxa , será que aqui não sai briga? Será que aqui...mas não. era um negócio tão bem organizado que não tinha briga, um negócio bem ajeitadinho, então, aí nós fiquemos.

Todas estas intempéries, aliadas ao desejo de conquistar a terra, construiu relações solidárias necessárias ao processo de resistência.

Queimou um barraco era podia ser de dia, de noite, sábado, domingo...era obrigado ir lá fazer o barraco pr'aquela pessoa. Aí todo mundo ajudava, um dava um banco, outro dava uma coberta, outro dava outra coisa, outro dava um colchão... (Manoel)

O próximo relato de José mostra a solidão presente em muitos por terem vindo para a ocupação sem a família:

Passei uns 3 a 4 meses sozinho aí...Sem ir em casa. Sozinho e Deus, sem a família... A mulher mesmo quando foi prá eu vim ela disse que não vinha. Que não me acompanhava...

Em outro relato de José podemos notar a insatisfação presente nas reclamações de sua esposa e que deve ter sido muito comum entre as pessoas no acampamento. Essa insatisfação é que, mais tarde, levou diversas famílias a buscarem outras áreas dentro do assentamento e, também, a ocupação das velhas casas que se encontravam abandonadas na Vila Smith a na Vila Mursa:

...ela sempre reclamava que nunca morou em barraco de lona...não é? Ela sempre reclamava daquilo... que tinha uma vida miserável...de viver num sofrimento daquele... ela sempre reclamou disso aí assim... Foi assim que surgiu, que tinha essas casa aqui... foi até ela mesmo que veio, mas um pessoal, ela disse as casas lá tá desocupadas. Aí se retira um casa dessas e 
vinhemos prá aqui. Aí melhorou a situação prá ela. Ao menos, prá casa melhorou...não é? E daí... estamos por aqui vivendo. (José)

Além dos aspectos já abordados sobre os recursos florestais, outros recursos naturais presentes na Fazenda Ipanema como a fauna nativa e a água ajudaram a formar o cenário deste novo contexto. A paisagem, para eles, tinha jeito de abandono, mas era cheia de beleza e esperança:

A terra já era cultivada há algum tempo, abandonada, ficou aquelas capoeiras, matas mesmo. (João)

Entrando na fazenda, entrando lá...no portão de Bacaetava. Não tem lá uma área às esquerdas? em baixo assim? Um banhadão.... (Toinho)

Segundo os relatos, a fauna na Fazenda Ipanema ainda é muito diversificada. Desde o período do acampamento eles se deparam com animais que circulam das matas do IBAMA: Onças, jaguatiricas e gatos-do-mato; capivaras e outros roedores; quatis; tatus; macacos e micos; além de pássaros; répteis e insetos, apareceram nas entrevistas.

Bicho... ah tem, viu... Veado...queixada...jaguatirica... Tem um monte de coisa ali. Aquele...como é que é... tamanduá...Tamanduá bandeira...qquele outro... mirim... (Chico)

Sobre a questão da caça, fica subentendido que, apesar da proibição por parte dos militantes, vários acampados fizeram uso rotineiro desta prática como única forma de ter acesso a uma fonte proteica.

Caça que tem mais de caça lá, tinha e tem é tatu. (Manoel)

Nesse meio de muitas pessoas, no meio desse povo todo sempre tem...não é? Sempre o pessoal saia, mas só aqui dentro do acampamento era proibido. (Chico)

Nessas falas pode-se perceber que existe um sub-texto implícito que denota uma auto-censura construída a partir da repressão feita pelos militantes desde os primeiros momentos, mas que foi sendo burlada por 'alguns' em função das necessidades emergentes. 
Matou, matou muito, é uma pena...Prá comer... ou matava ou nós morria de fome (risos). (Walter)

A gente andava tropeçando em tatu, tanto que tinha....bando de quati. $\mathrm{Na}$ época muita gente passou apuro, então, pela fartura que tinha e a posição que a gente táva era aceitável. Então fazia vista grossa nisso aí. (João)

Diz que a fazenda... não admitia de caçar. Se eles pegassem um, ao menos com um...aquela coisa de borracha... estilingue na mão...o próprio militante pegava o cara, avaliava e mandava embora... Não podia matar nada na Fazenda. (José)

Tinha (a caça) mas a gente não podia... Se eles soubessem... a coordenação que tinha segurança. Se soubesse que uma pessoa estava caçando, sei lá o que...era punido.... Primeira vez eles faziam uma assembléia punhava a pessoa em cima do caminhão prá todo mundo tá perante, e alertava aquela pessoa perante o acampamento inteiro. Essa pessoa tá sendo punida por esse motivo assim, e se tornar em outra ele vai ser expulso do acampamento. Quer dizer que era esclarecido... Então, jamais nem pensava em caçar. (Roberto)

...se eu contar prá você quando eu morava na cidade, se falava de comer determinadas carnes eu achava um absurdo, mas eu aqui dentro, fui uma pessoa que superou mesmo. A gente ia no barraco do cara, o cara tava com um quati lá e oferecia. Tatu mesmo, quantas vezes. Me lembro que eu comi um cachorro-do-mato...na panela, com tempero. Parecia carne de panela (carne de égua). Gato, na casa do Sr. M... se você crê, diz que é frango...jibóia, cascavel... (João)

Alguns atribuem a acidentes nas queimadas, como justificativa ao uso eventual em sua alimentação da carne de animais silvestres:

Falar a verdade a gente não vai nem mentir. Comigo mesmo aconteceu até de por fogo numa palhada que a gente fez o aceiro em volta, prá plantar lá, que nem foi plantado uma roça comunitária... e lá até queimou o tatu. 0 bichinho táva lá acabando de morrer, esperneando lá. Então a gente pegou... Isso aí acontecia de... em queimada mesmo aconteceu. Mas sair a propósito mesmo... prá ir caçar... não tinha jeito mesmo. E nem ia mesmo... (Roberto) 
$\mathrm{Na}$ questão da água ficam explicitadas, com muita evidência, as enormes dificuldades que foram surgindo a partir da ocupação. No início, a existência de água foi motivo de esperança. Num segundo momento, eles tomam consciência da realidade, dada a limitação do recurso água em função da grande pressão existente:

Água prá beber... nós afundô dentro da mata, os homê, mulhé e tudo. Cada um com um balde na mão, arrumou uma mina lá na mata... (Maria)

Água prá beber era o seguinte. Aquele córrego que passa na área 1, era uma água pura, nativa mesmo, por causa da serra... (Toinho)

A água, nossa, era péssima... Era pior do que nós tem aqui no caso... porque era fraquinha e muita gente. $O$ senhor sabe que a onde há muita gente, alguns preserva até a própria natureza ou a água que a gente depende dela e o outro já chega e já vai bagunçando... (Roberto)

Outros diálogos passam a relatar as saidas encontradas para a questão da carência e do suprimento de água no acampamento através do apoio das prefeituras vizinhas de Sorocaba e Iperó:

Nos primeiros dias vinha de Iperó a água...não é? caminhão pipa. Aí daí prá frente, como era muito dificultoso... ficava uma fila com mais de...quase meio quilômetro de distância prá pegar um balde de água... (Toinho)

A água... começou em Iperó mandá um caminhão Chevrolezinho velho, a gasolina, de tanque tudo enferrujado, trazia pru povo. Então aquele caminhão vinha duas vezes por dia... então tinha uns pontozinhos, uma principal...não é? às vezes juntava dez famílias cum balde tudo em fila... aî os cabra vinha, parava os caminhão, abastecia, você pegava e ia pra casa. (Manoel)

Poucos dias também,.. ele cortou também, não veio mais... e a gente teve que se valer duma nascentezinha d'água... um córregozinho que tinha semelhante a esse daí... era bem mais fraco. Era todo mundo prá pegar aquela água... foi difícil. (Roberto)

E prá lavar roupa, nós encerquemo uma agüinha que tem pro lado de baixo da área 1, onde era uma horta antiga, nós cerquemos ali um... uma barreirinha, e aí fez aquela poçona. Água até limpa, só que ficava ruim quando chovia, ficava cor de leite. (Manoel) 
Quando a prefeitura de Iperó parou de fornecer água, um caminhão pipa da prefeitura de Sorocaba manteve o atendimento até o ano de 1996.

Água tinha...de três minas...e as três minas não dava conta e...ainda vinha caminhão pipa de Iperó. E vinha um caminhão pipa de Iperó e outro de Sorocaba... (Chico)

A partir de um determinado momento, alguns começaram a abrir poços:

Aí dai prá frente, como era muito dificultoso... ficava uma fila com mais de...quase meio quilômetro de distância prá pegar um balde de água, ai... todo mundo se optou de furar poço, ou até mesmo andar um pouquinho mais, mas pegar na mina...não é? (Toinho)

Outro item inquirido foi quanto à alimentação, que trouxe as questões da arrecadação e dos apoios pessoais e institucionais recebidos.

... nós ocupamo no dia 16 ...não é? então no dia 17 já tivemo que montar uma cozinha comunitária. E, onde, nessa cozinha se alimentava mais de duas mil pessoas. (Toinho)

O Movimento tinha uma equipe de arrecadação, que fazia arrecadação, que se deslocavam, uma equipe para tal cidade, outras prá tal cidade e...tal e tal... e tinha os dias de reunir todos numa igreja e no... sindicato, onde eles faziam o depósito e, após uma carga, uma lotação boa, uma certa quantidade, então eles mandavam prá fazenda, pro acampamento, e aí era dividido por parcela, por proporção, conforme a quantidade de familia que tinha na casa, de pessoas na casa, então eles iam dividindo... (Roberto)

Vou falar a verdade mesmo, ó...era uma xicrinha dessa aqui, ó... quando a gente ia pegar lá. Era uma xicrinha de arroz, uma de feijão e uma xicrinha de óleo. Isso aí foi durante um ano e pouco desse jeito. Um ano e pouco foi desse jeito aí. Era uma xicrinha de cada coisa... (Chico)

...Só não vinha mistura. Negócio de mistura não vinha...mistura... carne, essas coisas não vinha. Era açúcar, café, óleo, feijão, arroz, farinha de milho, sal, açúcar... essas coisinhas assim. (José)

O próprio governo começou a mandar a cesta básica, uns 5 meses mais ou menos, depois cortaram (Walter) 
Nestas falas pode-se entender como foi o processo. Inicialmente, o MST conseguia o alimento, para tanta gente, através das equipes externas de arrecadação. Primeiramente, a organização utilizava como mecanismo de distribuição interna, o preparo e a realização das refeições em uma cozinha comunitária. Num segundo momento, a distribuição do alimento passou a ser diretamente para cada família.

Aí como foi chegando muita doação e o pessoal, a família por si própria queria ficar mais... a ter a sua cuzinhinha, ali na sua casa, no seu barraquinho ali... prá ele mesmo fazer sua comida e se alimentar aí foi esvaziando a cozinha e ficou melhor prá trabalhar... (Toinho)

Ainda de Toinho, há um trecho que reflete bem o seu cotidiano como coordenador da equipe de cozinha:

Fui nomeado por um monte de grupos que tinha sido montados prá ser o coordenador dessa cozinha, que eu nem queria por saber que seria uma barra muito pesada, sabe? Eu tive que fazer um trabalho com no mínimo 5 equipes... de mulheres... cada equipe continha 16 mulheres em cada equipe...Prá fazer uma... um trabalho que não ficasse cansativo prum grupo nem prá outro...não é? um grupo assumia de cedo até o meio dia. De meio dia entrava outra assumia até as duas...não é? Das duas assumia outra e ia até as quatro e ia assim até a meia noite.

Conseguir carne de gado era muito difícil... Eis, então, algumas saídas relatadas:

Às vezes a gente arrumava algum pedaço de carne que às vezes a gente arrumava um dinheirinho, aí saia lá no açougue e comprava aqueles pedacinhos de carne... (José)

Tinha um açougueiro ali, aqui no Bacaetava, que é Seu Aliseu...ele mata boi...não é?... Aí ele desossava aquela carne daqueles ossos, às vezes de ficar osso assim...mas...o pessoal ia lá e ele chegava e doava aquele ossos pru pessoal fazer caldo... fazer sopa... Dava mocotó... aquela barrigada do boi ele chegava lá e o pessoal chegava lá e ele dividia cada um um pedacinho... (José)

Ou através de 'rôlo': 
Aí foi o negócio de matá a vaca... roubá a vaca da vizinhança... mas fora. Aí o bicho pegou, rapaz. Porque quando nós roubava lá, matava e comia.... Então a isto se... apossearam. Então podia comer à vontade foram lá comeram uma vacas, comeram um bezerro, comeram duas... duas vacas. Tá lá o couro, tá isso, aquilo... .(Manoel)

Quanto ao alimento cultivado no acampamento, parte era destinada à venda e parte para o consumo imediato:

Praticamente foi o segundo ano. A gente plantou melancia, milho, plantou abóbora, foi plantado bastante, e... praticamente foi a maior força. Do segundo ano em diante, o terceiro... é... o terceiro ano, o segundo ano foi feito uma horta comunitária... Essa horta foi tirado verdura. Várias verduras também para o sustento da gente também, e outra, prá comercialização também, prá o próprio sustento da gente que... a verdura vendia lá fora $\mathrm{e}$ comprava alguma coisa que faltava pro acampamento, prá abastecer o acampamento... (Roberto)

No início nós planto foi couve, repolho, batatinha, abobora, quiabo, maxixe, jiló, essa melancia, feijão. Tudo nós plantô. (Maria)

Entrando na fazenda, entrando lá...no portão de Bacaetava. Não tem lá uma área às esquerdas? em baixo assim? Um banhadão... era Ali que era implantada a horta. A hortaliça era implantada ali e cá em cima, do lado de baixo, na área 1 tem uma faixa de terra assim que tinha bastante água naquele córrego. (Toinho)

Então, cavemos uma estrada, a mão mesmo, lá em baixo o pessoal abriu outra estrada e levou até o córrego e essa plantação de hortaliça que saiu dali foi tudo molhada com irrigador. (Toinho)

A assistência técnica nesse período foi dada pelo próprio MST, através de um militante recém formado:

Naquela época veio um cara do Pontal do Paraná prá cá, não... de Santa Catarina...até hoje ele é da direção estadual do Movimento, o (...)...não é? que ele tava se formando em agrônomo e deu algumas orientações prá nós por que ele tinha acabando de se formar havia pouco tempo...não é? Poucos dias e veio prá cá. Aquilo que podia ajudar e táva dentro do 
conhecimento dele... foi indo... até acabou aprendendo muito aí com... (Toinho)

Quanto aos apoios recebidos, a fala do João é esclarecedora:

$\mathrm{Na}$ época foi uma mobilização muito grande, tanto com deputados que apoiaram a luta como com a igreja, sindicatos, outros movimentos populares, prefeito, a imprensa da região no sentido de conseguir apoio dentro da própria população.... teve aqui alguma pessoas aí, alguns políticos da região que eram totalmente contrários, como é até hoje, que têm pretensão nas terras, inclusive.

Após a ocupação, a liderança do assentamento negociou com o IBAMA dez tratores que não estavam sendo utilizados pelo órgão. Parte destas máquinas encontrava-se em péssimo estado de conservação e não tinha como ser utilizada. Algumas terminaram como sucata. Até hoje encontram-se ferragens espalhadas na área 1:

Nós precisávamos de trator e implemento para o nosso trabalho, porque era muito dificultoso aqui... a... nós trabalhávamos aí no braço... não tinha nem condição...não é? devido a... muita terra e nós precisariamos de tratores. (Walter)

Em 93 mesmo, início, quando a gente fez a ocupação, a gente conseguiu conquistar em torno de 10 máquinas e vários implementos, apesar do desgaste, eles passaram os piores prá nós. (João)

Eram 3 tratores trabalhando, que preparou 80 alqueires de terra. Foi plantado milho verde... de todo, sabe? que você pensar que pode ser plantado em cima da terra ali tinha... de tudo... (Toinho)

Algumas dessas máquinas foram emprestadas, sem ônus, por fazendeiros da região como forma de apoio.

Ao levantar os aspectos educacionais, a preocupação da pesquisa foi a de verificar a existência ou não de um aparelho educacional disponivel para a comunidade recém chegada à região e a qualidade desse ensino, uma vez que um sistema educacional eficiente poderia influenciar as representações da floresta. 
Nos primeiros três meses de acampamento a prioridade estratégica da organização visava ações apenas nas áreas da segurança e na busca de sobrevivência. Após esse pequeno período, foi construido um barracão onde funcionaria a primeira escola ou sala de alfabetização. No relato do Toinho fica bem descrito:

Aí fui lá e negociei isso lá, com a Secretaria do Ensino (de Piracicaba), veio umas 150 cadeira de lá, de Limeira também veio uma 200 , por aí, e... construímos aquela escola, muito grande. Aquela escola muito grande, até mesmo de lona preta, bastante janela prá correr ventilação...

Os professores eram jovens assentados mais escolarizados:

...como veio na época.... muitas moças e muitos rapazes...não é? que era professor, foi fácil, foi só discutir com eles prá dar aula pra's crianças naquele período. ... Aí a foi...a direção na época procurou essas pessoas...não é? que eram professores, que tinham vindo na época, colocaram o problema que nós tinha com respeito ao ensino, se eles topavam...não é? não tinha salário, não tinha nada, era a luta mesmo...não é? Aí eles aceitaram e começou...a escola funcionar ali dentro... (Toinho)

Junto com as dificuldades de manter a escola no acampamento foram surgindo mais vagas nos sistemas formais municipais vizinhos:

...você sabe...o assentamento... foi um processo que vai tão longo...no percorrer do tempo é como se fosse uma peneira...não é? Ali, muitos vai saindo, saindo...então o número vai reduzindo e logo já começou a estudar em Bacaetava. Tem escola em Bacaetava, parece até o quinto ano, quem tava fazendo o colégio ia prá Iperó...aqui em George Oetere, na área 2 tem escola, na época aqui na Fazenda funcionava uma escola, aqui dentro...o pessoal do Mursa prá cá passou a estudar aqui dentro. Agora grande parte estuda em Araçoiabinha da Serra... (Toinho)

No início, as escolas da região não tinham vagas suficientes para todos:

No começo foi difícil muita criança ficou sem estudar...Por que não tinha vaga, não tinha estrutura prá tanta criança. ...no segundo ano eles começaram a estudar só em abril. Mas foi com muita luta também. Muita prensa... (esposa do Sr. Walter)

No início não tinha...Teve alguma escola... Teve em Bacaetava...teve de começo lá... mas era pouca a escola. Quase não tinha nem professores nem 
professores nem nada... E não tinha vaga prá todas as crianças do acampamento, era poucos... (Roberto)

João faz uma avaliação da qualidade do ensino nas escolas da região: ...o nivel de ensino é baixo demais. Os professores não têm interesse. Não é como no meu tempo. As crianças em sua grande maioria, não têm interesse pela escola. Chega na escola, tá lá uma professora que tá lá só prá ganhar salário...No meu tempo, eu ia prá escola meio preguiçoso e tal, não gostava muito da escola mas as professoras se esforçavam. As professoras até brigavam com você, tinham interesse em ensinar. Hoje, o que agente percebe, não sei se pela desmotivação de não ter um salário adequado, o professor não tem motivação de ensinar.

A saída viável que ele nos coloca para melhorar a qualidade do ensino é a implantação da escola do Movimento dos Trabalhadores Sem-Terra. Só ela seria capaz de dar uma educação política aliando teoria e prática:

...seria um pouco diferente da escola tradicional... precisava existir na escola hoje é a formação política. Hoje a educação que o Movimento discute muito e que consegue colocar em prática nos assentamentos no sul do país por exemplo, prá lá, onde tá mais desenvolvida a luta do pessoal estruturado, é você pegar, ter a aula da teoria de como plantar o feijão e depois por em prática, executar aquilo....abrir realmente a mente da garotada, eles mesmo vão despertar o interesse deles de aprender. 0 resultado que a gente ouve falar de escolas desse tipo aí, o desenvolvimento é muito maior.

Já mais recentemente, outra experiência de escola aconteceu na área 2:

Tinha a Cláudia, tinha três professoras. São professora que... como dizia os outros, tinha o diploma mas... num chegava a encontrar um emprego na cidade...não é? no Campinas, em Sumaré, (...) então essas três professoras dava aula. Prum tanto cedo, um tanto de meio dia prá tarde, e tinha, prá, que nem o Luiz (jovem da Vila Smith), assim pessoa que... tinha muito rapazinho que não tinha estudo, então tinha dois professores que dava à noite, das sete até nove. O Zezinho era um e tinha outro um... moreninho, mas ele foi embora, desistiu. Então dava aula à noite. Nós fizemos um barracão, ali colado... com... um gás, então... dois lampião... Dava aula à noite. E dali eles ia estudar, só que o boletim, do... do negócio de tempo de 
estudo foi que... lá, o que eles estudou, estudou, não parou...não é? Mas também não entrou em proporção de nada. Só que estudou. Adiantou que quando entraram aí eles não rodaram nem um ano. Do jeito que entrou foi passando, foi passando... sim, não perdeu tempo. (Manoel)

Meu filho estudou lá mesmo na Fazenda. Tinha uma escola lá dentro... era boa. (Maria)

A escola não aparece como importante nesse momento para a formação de uma consciência ambiental.

Até o momento, foram apresentadas diversas questões relativas ao meio ambiente e demais condições de infra-estrutura, apoio e serviços no acampamento. Resta, para que haja uma compreensão deste contexto, mostrar, com mais detalhes, o modo de organização inicial e os processos de mudanças que foram ocorrendo ao longo do tempo até o momento da definição dos lotes definitivos.

Esta parte da análise é muito importante para que se possa entender as relações de poder instituídas. Essa estrutura é determinada pelo MST ainda na fase de preparação e cadastramento para a ocupação.

A organização é o locus onde circulam as relações de poder e onde se instala a estrutura hierárquica que vai definir o modo de relacionamento social e decisório no acampamento

Para alguns, o desenho da organização interna é claro e inteligível, ou seja, inserido em um sistema de significações ou relações lógicas pré-conhecidas, normalmente para as pessoas que circularam pelas esferas decisórias (lideranças) ou que foram ligadas organicamente à organização do MST. Para outros, essa estrutura é muito complexa, sendo suas funções pouco claras. De um modo geral, esse estranhamento é comum aos membros mais afastados da estrutura de poder.

Inicialmente, devemos entender que a ocupação é coordenada por membros da direção regional e estadual do MST. Essas pessoas são genericamente chamadas de 'militantes'. Após a ocupação se instala uma comissão coordenadora ou, 
simplesmente, 'coordenação'. O restante dos ocupantes é reconhecido, apenas, por 'coletivo'.

Tinha um coletivo, em torno de 650,700 famílias quase. Todo mundo dividido em setores. (João)

Quando chegou prá um ou dois ou dez tomar conta de 800 e poucas... cadastrados, era muita gente, então foi repartido em 17 brigadas... então ali tinha o coordenador e o vice coordenador... da brigada. (Manoel)

...na época chamava brigada, que era um nome até assim de pressão, num sabe? Depois que normalizou as coisas deixou de chamar aquele grupo de brigada e voltou a ser grupo mesmo... de família...não é? Assim era 17 grupos de famílias, numa faixa assim de 35 a 40 familias por grupo...não é? (Toinho)

Quando virou grupo nós táva com nove mês, de trabalho. Manoel)

Tinha o setor do milho, da melancia, da horta... e pessoas do mesmo grupo (ou brigada) estavam envolvidos nos vários setores. Pessoas da mesma brigada trabalhavam no milho, na horta.... Então tinham seus coordenadores. (João)

Os setores são também denominados de 'equipes":

De cada brigada se era obrigado a ceder um homem pra uma função no acampamento... Então assim foi repartindo, então ficou mais fácil porque eu pegava meus 16 pessoas, sumia pro mato e sabia meu dever. (Manoel) ...tinha uma equipe que abria então um poço e ajeitava a mina, melhor... Tinha uma equipe de barracos. Eu fazia parte da guarda. (Walter)

O controle dentro dos setores era realizado de forma hierarquizada. Cabia ao coordenador das equipes de trabalho e seu suplente manter a freqüência e a disciplina no grupo. Tratava-se de uma instância intermediária na hierarquia do acampamento

Negócio ali era caderno. Se você trabalhasse 1 semana comigo e você faltasse um dia você tinha que trazer ... (palavra inaudível) contando aberto porque a farmácia era lá dentro, a ambulância era lá dentro. Prá você falar prá mim: olha, eu levei minha mulhé, o meu filho no hospital... tinha que trazer (a receita). Porque você táva mexendo com, com a farmácia dentro do... do.. acampamento e encostado ao almoxarifado que era onde nós 
ficávamos... No fim da semana, era obrigado a passar toda aquela (... lista?) no almoxarifado... e na imprensa. Nós ia vê tudinho... o seu comportamento, se você trabalhou, se não trabalhou... quantos dias, porque foi... porque não foi... e aquilo ia valendo ponto. $E$ ai foi que começou a sair nêgo fora. la expulsando... Num quer trabalhar... rua! Não fez isso... rua! Outro fez bagunça... rua! (Manoel)

Ainda de Manoel, há um trecho que mostra a relação direta com a floresta dentro do controle estabelecido pelos dirigentes:

Eu saía com dezessete peão, então, vamos supor, não tinha nenhum pau cortado no mato e nem ali de roda do acampamento. Nós tinha uma esplanada de madeira, um... um depósito de madeira. Então, hoje nós vamos cortar madeira, pegava segunda-feira cedo, caderno na mão. ...Então aí tudo me procurava. O que nós vamos fazer Sr.? Nós vamos pru mato tirar madeira que nós não tem, e precisa fazer um barraco ou dois barracos, daqui prá manhã. Então tá bom! Um pegava na foice, outro no machado, outro o facão e nós subia aquela serra velha ali.. Lá nós cortava madeira, puxava carreador...

Eles reproduziram uma relação de mando fabril na estrutura que se pretendia comunitária.

A forma como surgiu a primeira associação - APROFI denota que esta não ocorreu como síntese do trabalho de organização anterior, mas como uma forma de responder à exigências externas para se conseguir recursos do Estado. Inclusive, a Associação recebe a denominação de Agroflorestal por sugestão de professores da ESALQ (Moitinho, op. cit.) para que o assentamento mais facilmente se legitimasse, já que encontrava-se junto à FLONA de Ipanema. Os assentados não assimilaram essa designação:

Associação Agroflorestal...não é?, que é a APROFI... Como a gente entrou tudo junto...não é? e... no momento a gente tinha uma grande precisão de ter uma associação reconhecida...não é? aqui dentro do assentamento. Até mesmo na época que diz táva prá vim um recurso, não sei prá que, na época... que já faz tanto tempo que eu já estou ficando meio esquecido... que recurso vinha... Aí teve essa precisão de montar essa associação. Só que muita gente queria no momento tá associado naquela associação e 
muita gente não queria. Aí...através de muita discussão, de grupo...foi uma discussão grande, aí o pessoal muitos acabou aceitando a montagem dessa associação. Montou a associação... tirado o presidente...vice, os demais... e começou a trabalhar. (Toinho)

Apesar disso, após a fundação da APROFI e a partir da organização em grupos de trabalho, passa a existir uma identificação interpessoal dentro dos grupos. Surge aí uma possibilidade de organizações mais autônomas, motivadas por certa fragilização na coordenação do acampamento. Essa situação permite emergir novas lideranças que, por sua vez, passam a encaminhar novas propostas as suas bases (dos setores ou grupos), indo chocar-se com antigas diretrizes e estratégias da coordenação. Esse conflito se amplia e vai culminar com a criação de mais três associações, o que é analisado pelas antigas lideranças como negativo para o encaminhamento das lutas.

A separação do Grupo 9, que deu origem à Associação Nova Era, foi o mais traumático no interior do assentamento. Houve muita discussão e até agressões físicas, causando a mutilação de uma das lideranças do grupo 9, que ficou paraplégico após o incidente e quase causando a morte de outro envolvido.

A seguir, trechos de um relato do Roberto, que explica com detalhes a cisão do seu grupo:

Então a gente tinha os coordenadores da brigada. Que nem um deles era 0 Seu Nestor... Então ele disse que ia formar um grupo...surgiu essa idéia de formar um grupinho particular porque o primeiro ano que a gente trabalhou, que nem eu citei, a gente plantou melancia, plantou milho, plantou várias coisas e foi colhido... e ninguém viu esse dinheiro e prá chupar uma melancia na época a gente teve de pagar dez contos uma melancia... Então nós achamos que trabalhar mais um ano dessa forma não tinha condições...Então aí surgiu essas 2 pessoas com essa idéia de formar um grupinho, e esse grupinho ia trabalhar dessa forma assim, assim... era dividido... a renda que desse e tal, então... foi juntando gente, foi juntando... dentro de um pouquinho dias que esse grupo formou táva com cento e tantas famílias.

$E$ aí os lideres do Movimento que eram a Vera, o Paulo, o Ovídeo... achou que não ia funcionar. Porque, praticamente, essas duas pessoas tavam 
formando um grupo maior, até quase, quase quanto o do acampamento. Então eles não concordaram com a idéia. Então eles foram lá, barraram, tentaram, sob ameaça gente, e a gente disse não, temos o nosso grupinho, prá trabalhar dessa forma não... Da forma que trabalhamos no ano passado a gente não vai trabalhar mais... Bom... sei que não teve acordo. não teve acordo aí chegou o ponto do que... expulsaram os dois líderes que eram do grupo...

O pessoal da área 9 na época, na época não, não... já não surgiu como associação... foi como... incidentes (dissidentes) mas na época não foi. Fui um ano ou pouco mais que formamos o grupo que foi registrado como associação, Nova Era.

...e afinal ficamos em vinte familias. Essa vinte famílias permaneceu aí, elas estão. Prá não dizer que são vinte, tem dezenove hoje, porque um foi prá Tremembé, o Ricardo... era das vinte. ... as dezenove ficou com Nova Era. Ai formou associação Nova Era. Só que associação Nova Era formou, vai, vai... sei lá... parece que só teve o nome de associação Nova Era e... bagunçou tudo. Hoje praticamente... eu nem sei se ela é válida ainda como associação, ou se ...já venceu... caducou alguma coisa, eu nem sei como é que tá...

Observa-se que a cisão do 'coletivo' foi uma contestação, um momento de revolta, mas que não resultou em uma nova proposta de organização diferente, permanecendo apenas o nome do grupo.

A criação da ASPAR - Associação da Vila Smith, foi outro movimento de resistência que envolveu cerca de 70 famílias que ocuparam, contrariamente às decisões da coordenação, uma vila de casas abandonadas da fazenda:

Aí nós tivemos em 94 ou 93. Nós fomos prá Tremembé. Teve outra divergência que surgiu aí a ASPAR. ...Nessa, o pessoal ficou separado. Depois desse racha, em torno de, mais ou menos, 70 famílias... (João)

Outra fratura no 'coletivo' foi a realizada pela Associação Filadélfia:

Aqui nós tivemos um problema muito sério na área 1. Onde sempre fez parte da área 1 , pessoas que hoje... eles criaram uma Associação, a Filadélfia, em torno de quarenta famílias. vinte e cinco são crentes. A direção sempre crente. (João) 
As quatro associações passaram a negociar, autonomamente, reivindicações de suas bases junto às instituições responsáveis pelo assentamento INCRA, ITESP, DAF e IBAMA. O surgimento do Conselho de Representantes foi, então, uma exigência do INCRA para facilitar as negociações. O Estado surgiu remendando os recortes sem que os problemas ficassem resolvidos.

O pessoal querendo dividir gastando energia aí com problema interno e a questão da luta pela terra um tempo ficou parada. E só retomou de novo com maior esforço que conseguiu chegar, hoje, no projeto técnico, a partir de uma reunião no INCRA que o próprio presidente do INCRA exigiu que se não tivesse uma comissão que representasse todos os grupos ele não aceitaria falar mais com ninguém. ...Aí foi criado o Conselho de Representantes, onde 10 famílias teria que ser representada por um... (membro) (João)

Até hoje, semanalmente, o Conselho de Representantes ${ }^{19}$ vem se reunindo, tendo sempre a presença do ITESP, que passou a ser a instituição mediadora dos conflitos internos e das demais questões técnicas advindas dessa relação.

As associações foram se consolidando em função de exigências legais, mas muitas vezes estavam distantes do cotidiano do assentamento. Percebe-se grande confusão quanto à funcionalidade, objetivos e até a identidade das associações. O texto de Chico reflete bem essa confusão:

A nossa é Filadélfia. Ela é Filadélfia também... Não! a Filadélfia é dos crentes...a nossa é a Nova Era. É complicado esse negócio aí... é quatro associação que tem aqui dentro... é a APROFI (a minha)...é um nome brabo de lembrar...APROFI, é isso aí...

Maria, quando inquirida sobre qual associação ela se mantinha ligada responde:

A do Toninho... E daí nós saímos prá cá mesmo. Nós não tem associação... Nós não montou mais.

\footnotetext{
${ }^{19}$ Conselho de Representantes - doravante chamado apenas por Conselho.
} 
A fala de Roberto localiza o foco decisório de criação das associações fora de seu âmbito pessoal ou da sua capacidade de participação:

Eu prá dizer bem a verdade, eu não sei explicar como surgiu essa idéia de associação... eu acho que foi por melhor... melhor... acharam eles, um meio melhor de organização, então colocaram esse negócio de associação... menos gente até... fica mais fácil de controlar um grupinho de menos pessoas do que de muita gente do que muita gente. Porque você sabe, mexer com gente sempre é complicado...não é? Então foi uma boa esse negócio de associação...

Esse "acharam eles", parece significar: eu não participei, eu não sei explicar... alguém fez por mim.

Após a criação do Conselho, as associações deixaram de ter uma prática orgânica. De modo geral, os grupos ou associações indicam um representante e um suplente que passam a atuar no Conselho. Pelos relatos trabalhados, aparentemente, apenas a Filadélfia ainda se reúne com certa freqüência e encaminha questões de interesse coletivo. A Smith também, vez por outra se encontra, mas com menos periodicidade.

O contexto da ocupação relatado pelos camponeses apresenta um quadro de como eles analisam hoje o que ocorreu no passado. Não dá a medida de como tudo se passou naquele momento anterior, mas de como os sujeitos que viveram essa história a estão reconstruindo no presente.

A história social foi contada como história de vida, onde situações de harmonia e conflito se entrelaçaram. As necessidades constituíram o grupo social e colocaram seus membros diante de diversos problemas com o Estado, de relacionamento entre eles e de confronto com a natureza.

\subsubsection{Consolidação do grupo social: os lotes definitivos}

- A divisão dos lotes

Junto à separação do Grupo 9 e em seguida à ocupação por eles da área correspondente aos Campos Realengos, aconteceram outras ocupações - das casas da Vila Smith, da Vila Marcílio Dias e da Vila Mursa. Em 1994, houve também a ocupação 
da área do aeroporto, pertencente ao Ministério da Agricultura (área ainda em processo de litígio) e a liberação, pelo IBAMA, de uma área de 40 hectares em George Oeterer. Com isso, as 148 famílias restantes se espalharam ao longo de toda a fazenda, ainda em caráter provisório.

Calhou que, vamos supor que o meu lote não era esse daqui...não é? o meu lote era lá, mais próximo a Bacaetava. Aí então, ajeitando os lotes, é...foi criado mais lotes, porque num dava, né? porque foi feito assim um negócio meio...provisório, aí, depois, cada um ficou mais ou menos onde estava. Só que o meu lote foi extinto e o único lote que me sobrou foi este aqui, então eu vim prá cá... (Walter)

Aí começou a dividir a terra. E vai prá lá. Aí tinha muita gente, tava apertado. ...Que o IBAMA liberou um pedaço de terra lá que diz que é pros Sem Terra daqui. Vamo lá. Somos só nós três mesmo e vamos. Aí nós juntô só nós três e veio prá'qui. Daqui mesmo deu certo. Nós fica aqui mesmo. (Maria)

O DAF concluiu em 1996 o trabalho de planificação de uso das terras definindo as áreas de exploração e as áreas destinadas às reservas legais e obrigatórias. As áreas foram divididas segundo alguns critérios que resultaram em:

- Áreas com potencial para pecuária - lotes com áreas entre 10 e 15 hectares. A maioria deles localizados na área 1 (Bacaetava).

- Áreas com potencial para fruticultura e agricultura mais intensiva, com possibilidades de uso de sistemas de irrigação. São lotes com áreas de 7 a 9 hectares, demarcados sobre solos, em sua maioria, latossólicos mais profundos, relevo ameno, de excelente aptidão agrícola e pouca limitação de uso e maior proximidade de recursos hídricos (lagoas e represas).

- Áreas denominadas de 'Para-Rural', pequenas manchas, de boa qualidade, que ficaram com espaços muito pequenos, entre 3 e 5 hectares, e que se destinariam a famílias reduzidas em número de membros.

A partir daí, o Conselho de Representantes, junto com o DAF, realizou a divisão definitiva dos lotes através de um processo de 'pontuação'. O assentado que 
estivesse com algum tipo de produção em determinada área, o lote que caísse ali após a demarcação seria de sua posse. Caso houvesse alguma reclamação ou interesse de outro assentado sobre essa área, o Conselho aplicava a 'pontuação' para decidir a posse. Critérios como: número de filhos, idade, tamanho da família contaram nessa pontuação. De modo geral, o processo foi bem conduzido pelo Conselho, tendo acontecido, na área 2 , apenas dois ou três casos isolados de pessoas que se sentiram lesadas e se recusaram a deixar os lotes e se encaminharem, conforme o combinado, para as áreas definidas pela pontuação. Estas pessoas correm o risco de terem os seus cadastros cortados junto ao INCRA caso não acatem a decisão superior.

- A espera para ocupar o lote definitivo

No período correspondente à realização da coleta de dados da pesquisa, outubro de 96 a julho de 1997, diversos assentados ainda não haviam se mudado definitivamente para seus lotes. Era um período de transição. Mesclavam-se situações de indefinição quanto à ocupação do lote com outras situações referentes à produção. Alguns se mantinham à espera de que se realizassem as colheitas de roças pertencentes a terceiros em seu terreno.

Olha, eu tou vendo ele como um sonho ainda. Ainda é aquele sonho ainda...não é? Porque a gente não realizou ele... Eu tô numa área de terra que não é minha. Então, não posso até fazer o que até a gente pretende, quer dizer, condições agora no momento eu não tenho...não é? (Roberto)

No começo do ano em diante eu tenho que estar mudando porque aqui ficou prá mim até eu tirar a mandioca...não é? a mandioca vai sair no mês de abril, mais ou menos. Daí de janeiro em diante eu tenho que tá começando...não é? a mudar prá lá fazer alguma coisa prá lá. Tenho que fazer poço ainda. (Tião)

Outra situação encontrada foi a de produtores que aproveitavam esse período de impedimento para ir adiantando a construção de casas definitivas ou ainda provisórias, fazendo a abertura de poços ou pequenas obras de infra-estrutura. 
De qualquer forma, todos viviam na expectativa quanto à liberação do crédito habitação no valor de $\mathrm{R} \$ 2.060,00$ (dois mil e sessenta reais), pelo Banco do Brasil e que iria viabilizar a construção da casa nova ou reforma das atuais moradias.

O ano passado que eu vim cobrir de telha velha ó...eu ganho pouco tenho que comprar telha velha. mas o resto era de lona assim ó...manhecia o dia goteirando em cima de você... Uma hora dessa era melhor ficar lá no sol do que aqui dentro. porque lá ainda corria vento e aqui nem vento entrava. (Manoel)

- A abertura dos lotes definitivos e limpeza dos terrenos

As primeiras operações já no lote definitivo - abertura e limpeza do terreno - mostram o nível tecnológico disponível no assentamento, as dificuldades encontradas pela carência de infra-estrutura e apoios diversos neste momento crucial do preparo inicial do solo. Nos depoimentos seguintes, os camponeses explicitam o modelo de agricultura que está sendo reproduzido na fazenda através da forma como executam a limpeza da área.

Toinho detalha todos os passos por ele utilizados nessa operação de abertura do lote:

É... recomendado de não colocar fogo...não é? primeiro porque o fogo... prejudica muito a terra...não é? o próprio adubo orgânico que tá ali em cima você vai queimar e a terra vai ficar limpa ali que nem um 'busso' não é? Então você...se tiver muito forte, um colonião muito brabo você é obrigado a passar um fogo...não é? do contrário, é feito o serviço com... passa o gradão em cima...não é? mais leve, casqueando, dá aquela deitada e depois você vem com um tombador mais raso, com profundidade de 25 a 30 centímetros, tomba aquela terra e depois você gradeia, nivela e a terra tá preparada...Esse ai não tem problema até hoje...não é? Chegar a um lote para fazer o cultivo de uma área que já foi plantada... (Toinho)

$\mathrm{O}$ produtor define sua posição quanto ao uso do fogo e demonstra saber sobre a importância da conservação da matéria orgânica para o solo. Recomenda um 
sistema de uso de máquinas que parece já ter sido experimentado e aprovado por ele em operações anteriores nas áreas já cultivadas.

José relata suas experiências colocando a opção pelo uso do fogo por falta de condições objetivas e recursos necessários para cumprir as etapas descritas por Toinho:

...de acordo com o lugar tem que queimar porque se não não tem nem jeito de virar a terra. Por exemplo, tá um capoeirão... um capinzão bruto aí... aí tem que roçar prá depois tombar. Ali tomba e depois tem que dar 3 ou 4 mãos de grade para a terra ficar boa...não é? Nós não tem condições de fazer isso. É por isso que as vezes você passa um fogo prá melhorar a situação...não é? Aí passa um fogo, baixa ali, tomba, com uma gradeação e uma nivelação, aí a gente planta. ...Porque o certo mesmo é não queimar... (José)

Walter, entretanto, parece já ter abandonado tal prática, pois a responsabiliza como um fator de destruição do solo:

De início aqui nós abrimos no braço... fogo, porque nós aqui não tinha condição, máquina não, máquina nem...nem pensar, era... era foice mesmo e... enxada... Mas todos, todos eles teve muito fogo, uma pena...não é? A gente fazia aquilo com dor no coração porque não tinha meios, num tinha nem... vai fazer o quê? A gente sabia que, infelizmente, nós, né... estava estragando o solo que mais iria trabalhar, mais não tinha outro meio

Já Tião, coloca sua decisão de usar o fogo ou não em função do prazo que terá para preparar o solo. Ele também acrescenta a preocupação de manter o solo coberto com matéria orgânica:

É... se tivesse pelo menos uns 2 ou 3 meses prá deixar era bom tombar e deixar apodrecer o mato...não é? Agora nós vamos ver se vai dar prá fazer o serviço, se não der vai ter que roçar ele...não é? e dai dar uma sapecada por cima. Vamos ver se... se não precisa fazer isso ...não é? Deixar apodrecer o capim até o milho vem melhor....não é? (Tião)

Chico externa a sua contradição quanto ao uso do fogo em duas falas proferidas em momentos diferentes: 
Tem aquela gradinha... tem meia tomba... Tem aquele outro lá que quando passa o trator, por exemplo, você passa o gradão aí a... por exemplo, se passar num capim gordura ou numa braquiária, a braquiária sobe...não é? aí você coloca 2 pesos em cima dele, que é um triângulo...não é? aí você coloca na tração animal... coloca e ele vai arrastando... arrastando e depois, você vai tocando fogo.

Não uso o fogo porque... enfraquece o solo...não é? Enfraquece bem o solo.

Porém, Manoel faz uso sistemático do fogo para o controle de gramíneas: O gramão tava que nem o do vizinho assim... Aqui não tinha um pé de sombra prá você encostar de baixo. Foi na base de trator e fogo. ...hoje tá difícil de usar fogo porque as mata tá mais baixo. Mas aqui e acolá também que precisa nós põe fogo também porque... Aqui tem uma grama mundissada aqui ó... que se você carpir ela hoje e chover... daqui a 3 dias ela pega todinha. (Manoel)

Com exceção de Manoel, os demais assentados manifestaram conhecimento dos riscos no uso do fogo como rotina em seus tratos culturais, apesar de muitos o terem utilizado pela falta de outros recursos.

- Dificuldades e soluções

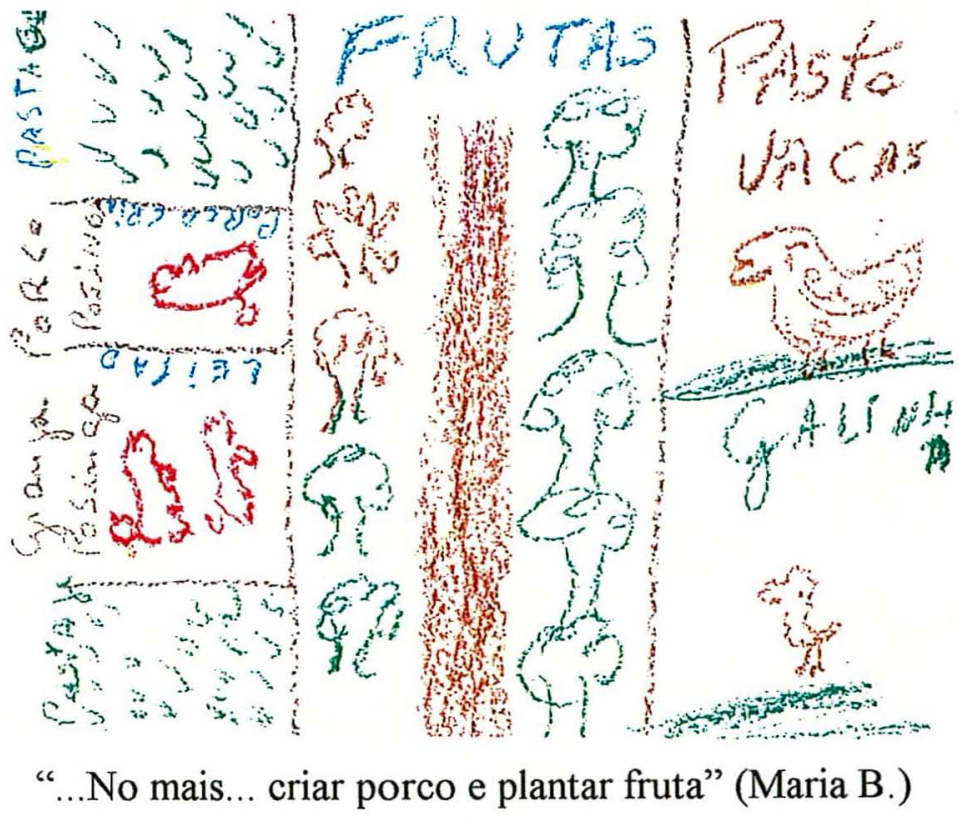

Figura 7: Desenho esquemático do projeto agropecuário 
O contexto de vida dos novos camponeses da fazenda Ipanema já com seus lotes demarcados, lhes traz a novidade de agora se sentirem mais seguros e mais perto de concretizarem o sonho de terem um lugar só deles para viver.

Esse sonho presente no momento da pesquisa facilitou a realização da proposta do pesquisador de que representassem graficamente o que projetavam para seus lotes e para o assentamento. Assim, houve uma troca descontraída desses projetos em pequenos grupos.

No entanto, esse contexto não apareceu cheio apenas de sonhos. Inúmeros novos problemas surgiram com a demarcação dos lotes definitivos. A primeira grande dificuldade relatada pelos sujeitos que participam das instâncias decisórias dentro da fazenda e de grupos de trabalho coletivo é a dificuldade na organização do assentamento "O Luiz tá no grupo dos irmão dele. Tá tentando organizar o pessoal, vê se consegue? Mas é, eu acho difícil, sabe. Por que hoje você tem uma cooperativa de produção precisa ter um nivel de organização muito grande. (João)

As associações não funcionam $\mathrm{e}$ todas as questões que exigem participação de todos são discutidas no Conselho junto com o ITESP.

Com o lote demarcado, cada família está vivendo a expectativa da construção da casa própria e de conquista da independência camponesa.

A essa imagem da autonomia do pequeno proprietário de terra, que eles trazem de uma história antiga, foi acrescida a imagem de aprisionamento coletivo da experiência recente do acampamento. A maioria quer viver o seu sonho isoladamente. Para os que ainda querem uma experiência comunitária e uma mudança social, o parcelamento da terra realizou um retrocesso na organização, pois alicerçou o isolamento e o individualismo. Porém, ao mesmo tempo, na nova condição de camponês, eles enfrentam problemas que os obrigam a algum nível de organização através do Conselho. Esses problemas se referem à falta de recursos para produção e implementação de serviços (luz, escola, transporte) dentro do assentamento (Anexo E). 
Com isso, algumas soluções são encontradas no âmbito das familias $\mathrm{e}$ outras os representantes no Conselho negociam diretamente com o ITESP, INCRA, IBAMA etc. ou os militantes do MST os organizam para reivindicar através de eventos regionais, estaduais ou nacional, porque são problemas de muitos outros assentamentos

Dessa forma, o contexto dos lotes definitivos coloca os assentados de frente com as questões de sobrevivência na nova situação camponesa que não é mais aquela do acampamento.

O projeto de vida se delineia como um projeto agropecuário para todos, com inúmeras dificuldades de infra-estrutura, carência de tecnologias adaptadas, problemas na comercialização e no emprego pleno da mão-de-obra disponível dos jovens e mulheres.

Os militantes do MST e algumas lideranças internas do assentamento acreditam que a única solução é a cooperativa de comercialização, o associativismo na produção e a continuidade da luta, não só pela reforma agrária, como pela transformação da sociedade. Porém, a maioria dos camponeses ainda acredita no camponês isolado, embora já perceba que este isolamento lhes traz problemas sérios de sobrevivência.

Os 'coletivos' enfrentam inúmeros problemas na organização, alguns começam a desanimar, outros se atrelam às instituições governamentais, outros se dedicam mais às lutas externas.

Os 'individuais' se isolam ou participam apenas nas instâncias decisórias para resolver problemas de infra-estrutura e crédito no Conselho ou eventos nacionais programados pelo MST.

É dentro desse contexto que se apresentam as questões sobre a floresta, produzindo-se um saber sobre ela que se processa dentro desse conflito entre projetos coletivos e individuais, participação em instâncias de organização internas e externas, que trazem novas informações, modos de conhecer e agir sobre o mundo.

A Floresta Nacional de Ipanema é uma realidade em torno do assentamento; as reservas do assentamento estão delimitadas; várias discussões sobre os cuidados com as matas têm ocorrido desde a ocupação até os dias de hoje no Conselho; o 
lote já pode ser trabalhado dentro das condições dadas; os sonhos são, as vezes, ambíguos e se confrontam. É nesse cenário que o saber sobre a floresta se produz e se refaz.

\subsection{As representações da floresta pelos assentados}

O saber dos assentados da Fazenda Ipanema sobre a floresta se processa constantemente nas trocas sociais. As idéias que circulam no assentamento refletem os quatro anos de experiência grupal, com todos os sofrimentos, as expectativas, os acertos, as dúvidas, as crises, os sonhos, interpretadas por cada sujeito de formas próprias, pois ancoradas nas histórias de vida pessoal, mas todas elas imersas na prática e no mesmo imaginário social.

Nas histórias de vida contadas e nos sonhos que representaram graficamente e sobre o qual falaram em reuniões, surgiram temas em torno dos quais aparecem conteúdos sobre as flores, o elemento arbóreo e a fauna silvestre. A partir desses núcleos temáticos é que foram organizadas as representações da floresta e, posteriormente, foram articuladas todas estas representações para explicar o processo de produção do saber. 


\subsubsection{A casa e a árvore}

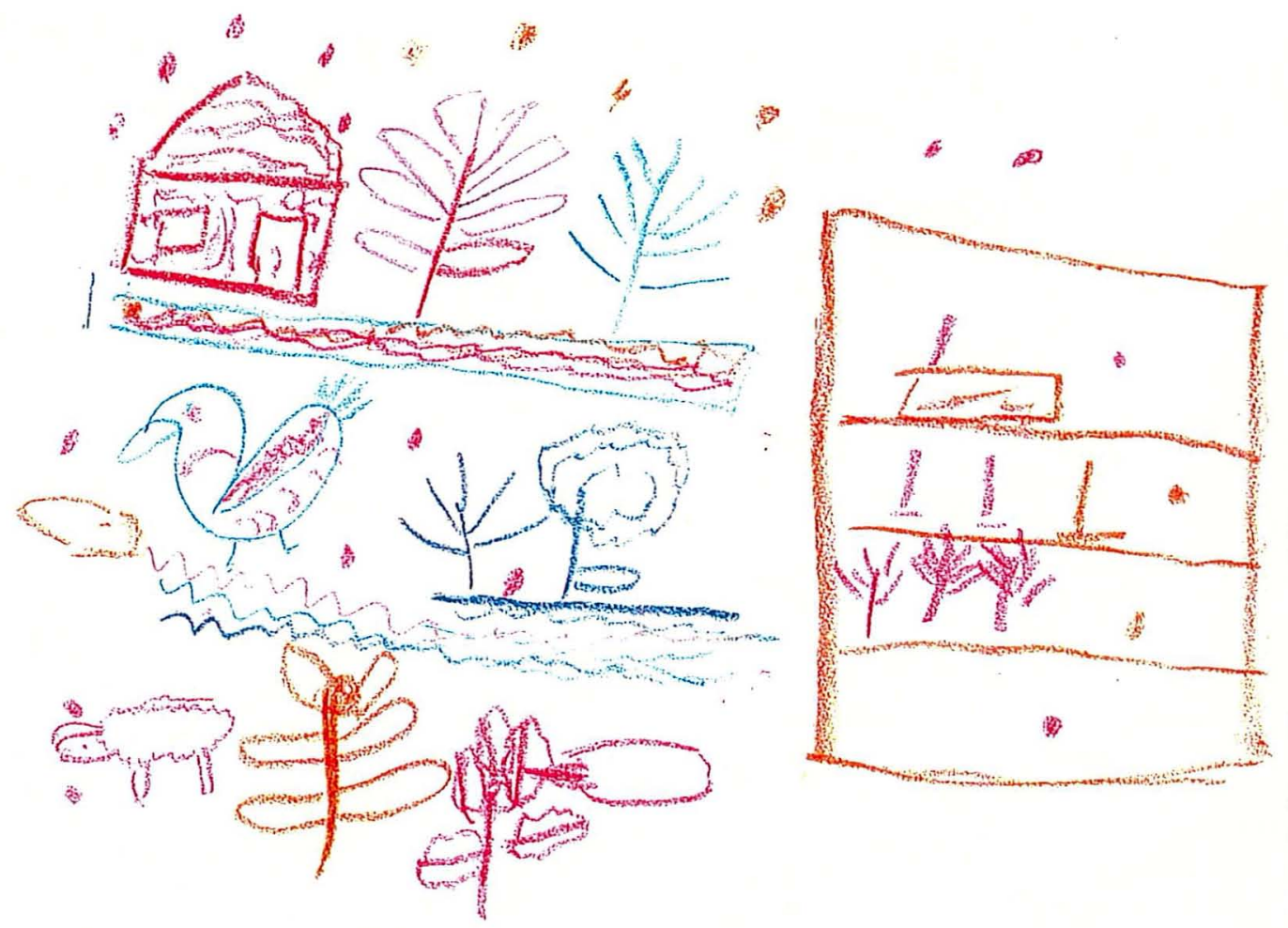

"Minha casa... as árvores que quero plantar em volta..." (Cláudia - desenho, Área 2)

Figura 8: Desenho representando a presença do elemento arbóreo próximo à casa.

Algumas falas dos assentados expressam a dimensão que a questão da casa própria tem no atual contexto dos lotes definitivos:

Construir uma casinha boa prá mim morar, que é esse meu sonho que eu nunca tive e ainda não realizei...não é?... Mas espero que aqui eu vou realizar. (Nieta)

Uma casa de tijolo bonita... (Ovídio)

Em primeiro lugar... um lugar prá morar. (Dito)

O elemento arbóreo aparece em torno desse tema como representando a sombra, o conforto, a beleza, as flores, principalmente na fala das mulheres. É a árvore acolhedora e como paisagem. 


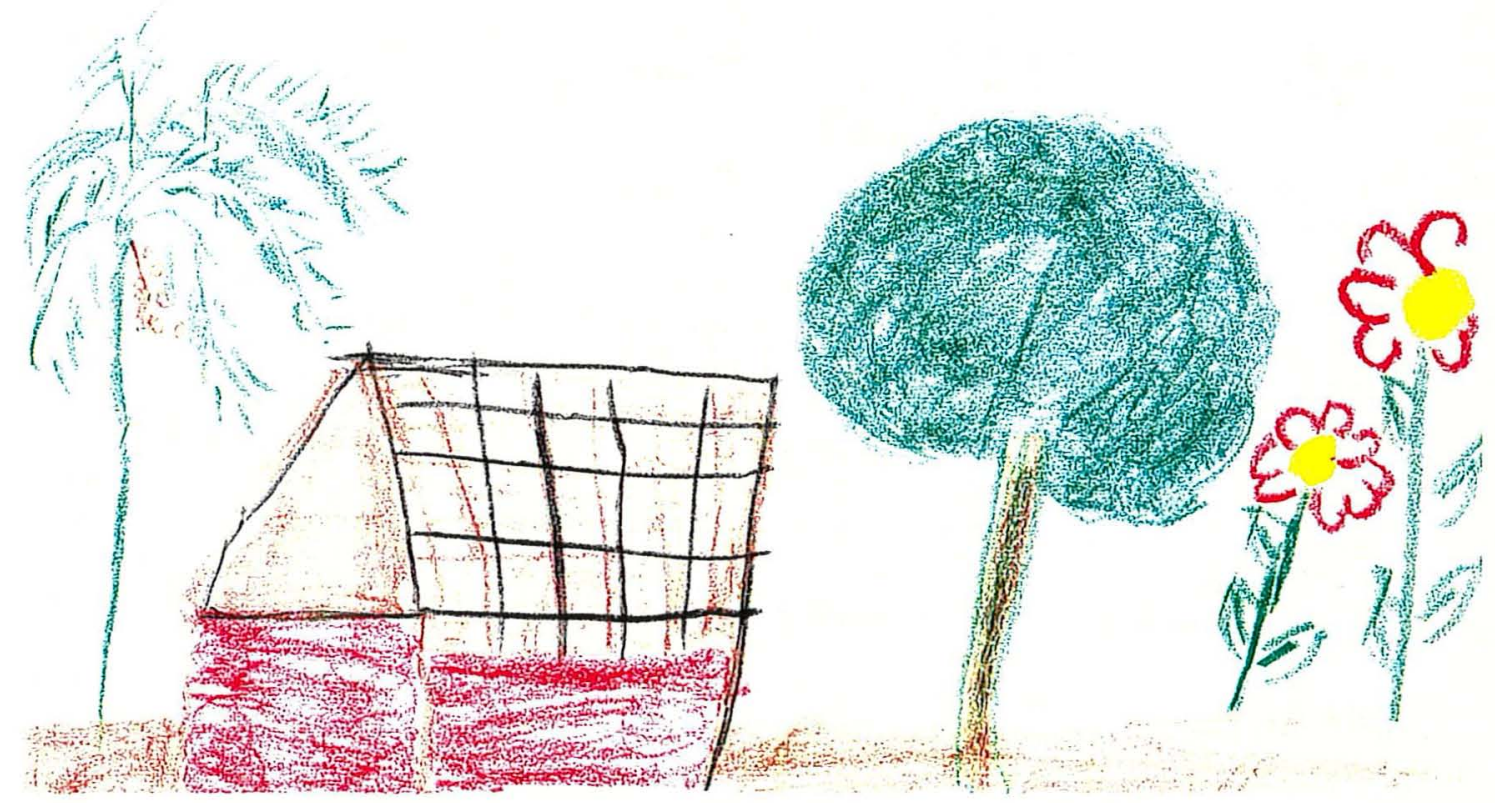

"Uma casa... um coqueiro... uma árvore... que é tudo que eu pretendo. Flôr... pés de fruta..." (Inês - desenho, Área 2)

Figura 9: Desenho representando a presença do elemento arbóreo próximo à casa.

Algumas falas desconsideram a questão das flores, mas valorizam as frutíferas que dariam sombra e alimento.

Eu o que eu tenho de idéia de plantar de arvoredo aqui é mais uma mudas de manga, abacate... arvoredo assim, que dê fruta. Você tá na sombra e tá enchendo a barriga. ... eu... pegar um pedaço de terra de 1 alqueire ou 2 alqueires e plantar árvore... prá ficar na sombra... e vê flôr...Que brincadeira besta. (Manoel) 


\subsubsection{O lugar da floresta nos projetos agropecuários}

A maioria dos assentados consideram que os lotes são pequenos e devem ser totalmente utilizados para a agropecuária. Os sujeitos que participam das instâncias decisórias justificam o tamanho dos lotes como uma opção do Conselho em atender a um número maior de assentados, acarretando a redução da área dos lotes. Por esse motivo, as árvores passam a ter um papel secundário nesses projetos. Nesse sentido, ela só aparece com muita ênfase na fruticultura, tanto para comercialização quanto para subsistência.

Alguns demonstram vontade de plantar o eucalipto ou árvores nativas para aproveitamento posterior em moirões, instrumentos de trabalho e barracões, mas apresentam essa idéia como intenção para o futuro. No caso dos sujeitos que exploram individualmente seus lotes, a preocupação em ter madeira para o futuro aparece como tarefa para a família. No caso dos que trabalham coletivamente, a mesma questão também aparece, mas como tarefa de todo assentamento, portanto o plantio de árvores deveria ser feito nas reservas (que são do coletivo).

A representação da floresta nos projetos agropecuários foi de algo que não pôde se combinar com a vocação dos camponeses, a não ser em casos isolados ou quando a pensam como pomar. Árvores são somente para enfeite e sombra em volta da casa e, no máximo, como cerca e quebra vento para alguns, como projeto para o futuro. ...a minha divisa com o IBAMA eu quero plantar, a cada 2 metros, uma muda de eucalipto prá servir de quebra vento...não é? (Toinho)

Nas falas sobre o sonho para o lote surgiu uma intenção de plantio de um arboreto sem fins utilitaristas explícitos nem claramente paisagístico. Porém, na representação gráfica as árvores apareceram como uma cerca divisória no fundo do lote, como na figura abaixo: 


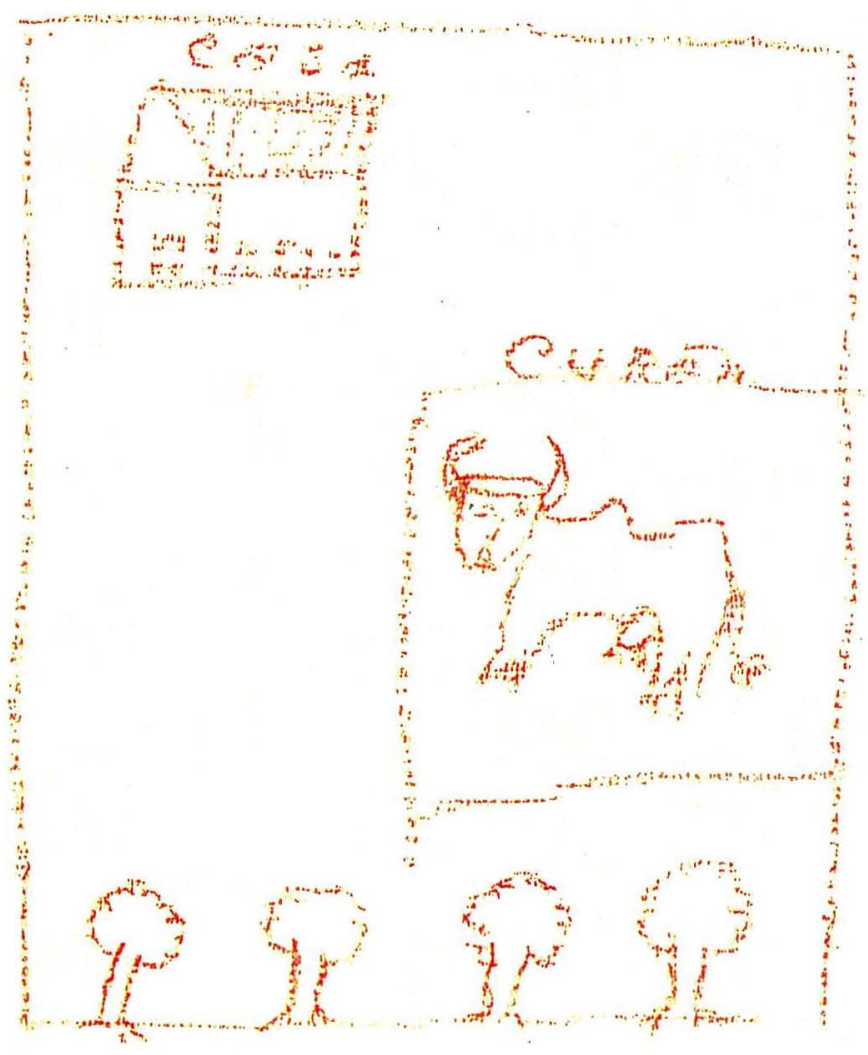

Pretendo plantar um arvoredo, não é? Qualquer tipo de árvore...não é? Pinho... ipê roxo (André - desenho na Vila Smith)

Figura 10: Desenho esquemático incluindo o arboreto.

Um outro entrevistado falou do seu interesse em plantar algumas árvores no pasto, para sombrear o local do cocho. Mais uma vez, a árvore representa sombra, mas agora, dentro do projeto de produção. Esse foi o único caso que aliaram a vocação agropecuária ao plantio arbóreo.

...No lugar que eu táva querendo fazer pastagem eu táva querendo plantar umas 4 árvores, ou talvez até mais, entendeu? Ela cresce bastante prá fazer sombra pru gado., certo e normalmente debaixo da árvore eu quero colocar os cochos... Até umas 6 árvores. (Pedro) 


\subsubsection{A idéia de preservação e de uso das reservas}

As várias falas sobre os temas 'preservação' e 'reserva' aparecem muito próximos, já que se considera que a reserva é o lugar onde devem ficar as árvores e a fauna. Embora tenham falado em preservação também nas nascentes dos córregos que existem dentro dos seus lotes.

A palavra preservação aparece em todos os discursos dos assentados pesquisados. Eles afirmam que já discutiam a necessidade de preservar as matas nos grupos de preparação para a ocupação, mesmo antes de saberem o local que seria ocupado. Ao chegarem na Fazenda Ipanema verificaram, como diz João, que ela estava abandonada, mas havia muita mata que não deveria ser derrubada:

A terra já era cultivada há algum tempo, abandonada, ficou aquelas capoeiras, matas mesmo, a mata que existia na época é a que existe hoje. O pessoal não mexeu em nada. Muito pouco. (João)

Após a divisão dos lotes e mesmo no período inicial do acampamento, consideram que não foi realizado nenhum dano para a floresta que já estava lá.

Observa-se que os sujeitos que participaram de instâncias decisórias é que se referem à idéia de preservação ligada à de proteção de manaciais de água: nascentes, córregos, lagoas etc.

Aqui tem uns focos de mata. Quero preservar, porque justamente, aonde tem, nossa nascente, no meio, então não quero mexer se não vai atrapalhar. Nos fundos do lote, eu tenho lá... passa nos fundos lá, um riozinho...não é? (Walter)

Entre os que trabalham coletivamente, mesmo os que não estão em instâncias decisórias, se explicita a compreensão do papel do IBAMA como órgão público, dimensionando o público como pertencente a todos os cidadãos brasileiros, portanto patrimônio que deve ser preservado. 
Esses mesmos sujeitos avaliam a fiscalização do IBAMA dura - vigorosa e repressiva, mas apreendem contradições na ação do IBAMA quando este permite que as mineradoras destruam o morro através de suas atividades.

É errado o que estão fazendo na pedreira aí no morro. Como vão fazer uma preservação aí no morro e tem um problema daquele destruindo. (Zé Luiz)

Entre os que trabalham em coletivos aparece, ainda, a idéia de que a preservação que se faz está ligada à consciência que se desenvolveu desde antes da ocupação. Entre os 'individuais' que estão fora das instâncias decisórias do assentamento, a preservação ocorre porque desde o início houve punição do MST e hoje do IBAMA. Estes mesmos sujeitos representam preservação como "lugar onde não se deve mexer", porque "já que não dá prá usar a reserva o jeito é preservar ela". (Roberto)

O conceito de preservação que circula no senso comum parece se ancorar, principalmente, na experiência do acampamento, tanto para os que disseram ser fruto de uma consciência pessoal (interna), quanto para os que a ligam a um controle externo (punição). Foi naquele momento, em especial, que o grupo recém constituído viveu a necessidade de 'preservar' a natureza. Porém ficou muito claro, em todas as falas, que houve uma coerção muito forte por parte do Movimento, com grande fiscalização. Esse foi o caso da palmeira gerivá (Arecastrum romanzofianum), espécie muito comum na região, por eles batizada simplesmente de "coqueiro", que foi protegida para se evitar a extração do palmito e de outras árvores de maior porte e exigiu uma pressão coercitiva por parte da liderança, ameaçando, inclusive, com a expulsão do acampamento para quem desrespeitasse essa decisão. $O$ fato torna-se relevante neste estudo pois ele vai determinar toda uma nova relação com o ambiente. A partir daquele momento, os assentados passaram a incorporar algumas preocupações com o elemento arbóreo, -embora se perceba algumas contradições nas suas falas, quando João, por exemplo, justifica a possibilidade do corte "porque a mata era grande" ou quando acredita que fazendo a retirada da madeira "mais longe" não prejudicava. 
Talvez o fato de estarem próximos a uma Floresta Nacional nas condições de negociação que foram obrigados a manter com o IBAMA, tenha, também, trazido o tema da preservação como obrigatório no cotidiano do assentamento.

A representação de preservação está ligada, primeiramente, à idéia de 'não tocar', 'não mexer' que foi delineada nesse início da vida grupal.

No entanto, outros personagens além do MST e do IBAMA passaram a fazer parte das relações da comunidade como organizações não-governamentais, universidades, sindicatos e o ITESP. Detectou-se, em muitas conversas e entrevistas, referências a informações recebidas por estudantes da ESALQ, que já traziam dados novos para a idéia de preservação construída anteriormente. Os assentados aliam ao conceito de 'preservar' à idéia de 'conservar', que acrescenta a possibilidade de um uso racional dos recursos naturais, embora mantenham, ainda, a palavra 'preservar' para designar essa nova significação.

Só se for fruta... plantar fruta dentro... o pessoal fala que pode...não é? Bom! assim o pessoal fala...não é? Mas o pessoal... não sei não... porque...nós já conversamos com o William ${ }^{20}$, com a... o pessoal fala 'Girasol' (Marisol) ${ }^{21}$...não é?... Ela falou que...conversando com os órgão aí... é perigoso dá certo...sabe? (Chico)

Porém, o uso sustentado das reservas fica sempre em segundo plano, algo que já parece possível, mas ainda longínquo, necessitando de mais informações e infra-estrutura. Nas falas onde a idéia aparece, há, muitas vezes, um pedido de ajuda ao pesquisador.

E essa beira de represa, esse brejo ai, a gente quer, principalmente junto com vocês também, a orientação do que que é melhor está plantando aí? (Jorge)

\footnotetext{
${ }^{20}$ William Goldoni Moitinho, fez estágio de residência agronômica no Assentamento da Fazenda Ipanema, em 1994 como aluno da ESALQ/USP. Atualmente, encontra-se formado em engenharia agronômica.

${ }^{21}$ Azeneth Eufrausino Schuler (Marisol), fez estágio de residência florestal no Assentamento da Fazenda Ipanema, em 1995 como aluna da ESALQ/USP. Atualmente, encontra-se formada em engenharia florestal.
} 
Então nós poderíamos até plantar uma...plantação de coisas nativa...aqui... alguma coisa que poderia pudesse... mas gerar dinheiro (risos) aqui prá nós no final...não é? Então nada melhor do que você nos ajudando nesse sentido...não é? (Walter)

Essa representação de uso sustentável vai permitir o surgimento de uma série de possibilidades novas para as reservas. Não seria apenas mantê-las intocadas, como em muitos momentos parecem entender. Porém, não há clareza sobre essas novas possibilidades. Nas conversas informais e sonhos para o futuro a representação de conservação aparece, de formas diversas, mas sem consistência, deixando ressurgir, em outros momentos, a representação inicial da reserva como intocável.

Pelo o que a gente tem tomado conhecimento aí... Sim, se a gente tivesse algum esquema de aproveitar ela prá tirar algum, alguma rendazinha disso á́... tudo bem...Mas eu acho que...prá nós se torna meio complicado...não é? É preservar ela mesmo e... (Roberto)

A questão que se pretendia levantar com o Roberto se relacionava à forma como via a possibilidade de um uso sustentado para as áreas de reserva.

A resposta foi dada em três fases: na primeira, ele demonstra que o assunto já circula, como informação, entre os assentados - "Pelo o que a gente tem tomado conhecimento aí... sim".

$\mathrm{Na}$ segunda fase, ele faz uma análise contextual, qual seja - "Se a gente tivesse algum esquema de aproveitar ela prá tirar algum, alguma rendazinha disso aí... tudo bem...Mas eu acho que...prá nós, se torna meio complicado...não é?". Nesta fala, fica evidente tanto a falta de recursos e informação que o impede de implementar ações que lhe pudessem auferir ganhos econômicos, quanto a dificuldade prática que é expressada com a frase: "se toma meio complicado...não é?."

Por fim, a solução por ele encontrada: "É preservar ela mesmo e...", nos remete para algumas reflexões. O termo 'preservar' foi utilizado três vezes durante a entrevista, sempre se referindo ao sentido de manter a natureza intocada pelo ser humano, "prá preservar a natureza", ou seja, manter a natureza cercada, isolada para que se possa protegê-la. Isso mostra que é um termo já introduzido no cotidiano dos 
assentados ao qual Roberto aplica os mecanismos de ancoragem e objetivação. A ancoragem se verifica quando ele se refere ao período da ocupação em que os militantes do Movimento restringiam o corte de madeiras da floresta ou proibiam a caça, aplicando punições caso alguém burlasse as regras pré-estabelecidas. A preservação torna-se um mecanismo social de relacionamento com a natureza utilizado sempre que não se possuir condições ou estrutura para interferir diretamente sobre a natureza para fins de geração de renda ou manutenção da qualidade de algum recurso natural.

Em outra fala do entrevistado em que aparece o termo 'preservar', a ancoragem foi feita em função da escassez de água potável:

A água, nossa, era péssima... Era pior do que nós tem aqui no caso... porque era fraquinha e muita gente. Senhor sabe que aonde há muita gente, alguns preserva até a própria natureza ou a água que a gente depende dela e o outro já chega e já vai bagunçando...

O mecanismo de objetivação que ele utiliza para elaborar a sua representação do conceito de preservação da natureza se aproxima do significado do termo 'preservação' no sentido ecológico, de isolamento gênico para a perpetuação da biodiversidade ou de uma determinada espécie. Ele objetiva o termo 'preservação' à situações de maior ou menor conscientização ... "alguns preserva.... o outro já chega e já vai bagunçando..."

\subsubsection{Animais silvestres}

Os entrevistados são unânimes em afirmar que várias espécies da fauna nativa são vistas, circulando na fazenda.

Tem o gato preto, que é o gato do mato. Tem aquele que a gente chama de frozinhos (?), uns cumpridinhos assim, não é? tem o cachorrinho do mato, esse já é mais curtinho, mais alto um pouquinho, duas orelhinhas idêntico ao cachorro...não é? Ah, eles passeiam aqui prá baixo, prá cima a toda hora. Tem o próprio gavião, gavião tem bastante aqui. Tem de bando. (Jorge) 
Bicho... ah tem, viu... Veado...queixada...jaguatirica... Tem um monte de coisa alí. Aquele...como é que é... tamanduá...tamanduá bandeira...aquele outro... mírim... (Chico)

Afirmam com tranqüilidade que, apesar das proibições do IBAMA e do próprio Movimento, a caça era uma prática aceita em função das péssimas condições sócio-econômicas em que viviam.

A gente andava tropeçando em tatu, tanto que tinha....bando de quati. $\mathrm{Na}$ época muita gente passou apuro, então, pela fartura que tinha e a posição que a gente táva era aceitável. Então fazia vista grossa nisso aí. (João)

Nessa fala se percebe a posição dos sujeitos que participam das instâncias decisórias e que têm uma preocupação maior com a preservação dessa fauna.

Para a maioria dos 'individuais' que mantém galinhas criadas soltas em volta da casa, a presença de alguns animais silvestres é considerada como uma ameaça, em especial a raposa, o gato-do-mato e o cachorro-do-mato.

Os animais vêm comer galinha... nós não pode matá... (Maria)

Já os 'coletivos' têm uma concepção de que com o uso de sistemas produtivos mais tecnificados haverá maior preservação da fauna, uma vez que as criações serão confinadas.

E...agora... um dos problemas agora dependendo da criação aqui hoje, com aquele pequeno, que tá criando as suas galinhas só soltas e aprendeu criar só daquele jeito e não vai aplicar a tecnologia, ela é complicado, as galinhas dele não vai durar muito, porque...tem bicho de todo tipo pra colher elas,...não é? Então ele consome. Se ele não comer quando é pequenininha a hora que tiver grande ele (o bicho) come. (Jorge)

Esse mesmo grupo de sujeitos considera que a questão da caça, ainda existente, deve ser enfrentada a partir de medidas repressivas, fiscalização e educação ambiental.

Mas de um tempo prá cá, a gente tá batendo duro nesse negócio aí (da caça). Depois que conseguimos consolidar o negócio da terra fomos pegando duro nessa questão. (João) 
É... porque... nós temos alguns...algumas pessoas aí que não... que tá.... é ...consumindo,...não é? alguns animal agora... hoje na visão assim eu acho que não tá havendo muito isso, a questão da caça...não é? e até é importante a questão de reprimir mermo não, apenas se você matar um tatu ou pegar você com um tatu ou alguma coisa assim e tão,...é... a pessoa que ora tem, de certa forma, tem que ter um medo prá poder seguir a regra...não é? Por que não é tudo que segue, sem... sem pressão não. Com consciência mesmo é... difícil. Eu acho que tem de ser feito bem mais trabalho em cima disso. (Jorge)

Os animais silvestres ganham significações diversas no assentamento. Para a maioria dos assentados não representavam, anteriormente, caça, até se encontrarem na situação de carência de conseguir outras possibilidades de proteína animal diante da oferta que encontravam na mata.

...se eu contar prá você quando eu morava na cidade, se falava de comer determinadas carnes eu achava um absurdo, mas eu aqui dentro, fui uma pessoa que superou mesmo. A gente ia no barraco do cara, o cara táva com um quati lá e oferecia. Tatu mesmo, quantas vezes. Me lembro que eu comi um cachorro-do-mato... Na panela (carne de égua), com tempero parecia carne de panela. Gato, na casa do Severino... se você crê, diz que é frango...jibóia, cascavel... (João)

O próprio uso do animal silvestre como alimento objetivou a sua representação como caça. Porém, com o controle das lideranças e dos aparelhos do Estado, os animais silvestres passam a representar, para muitos, uma fauna que deve ser preservada. No entanto, essa idéia de preservação da fauna entra em choque com a necessidade de proteção dos animais domésticos e das plantações no atual momento. Dessa forma, há uma ambigüidade na significação dos animais silvestres. Soluções como as apresentadas por Jorge vem sendo experimentadas no assentamento, mas há relatos sobre uso persistente, principalmente de carne de tatu, por alguns assentados. 


\subsubsection{As representações se articulam e orientam práticas}

Nas representações da floresta pelos assentados, a árvore traz a sombra e o embelezamanto da moradia, além do quebra-vento e da madeira que vão precisar no futuro. A presença dela parece que não se combina com a lavoura e a pecuária. Assim, $o$ elemento arbóreo deve ficar na reserva para ser preservado junto aos animais silvestres. Essas representações, articuladas no dia-a-dia, têm orientado as seguintes práticas concretas:

- não se mexe nas reservas, mesmo porque isso exigiria trabalho coletivo, já que as reservas não são das propriedades mas do assentamento;

- não priorizar o plantio de árvores, mesmo em torno das casas como dizem querer, considerando-se que as casas ainda não são definitivas;

- não haver iniciativa de construção de viveiros de mudas para a arborização futura do assentamento;

- plantio generalizado, em muitos lotes, de frutíferas.

Observa-se então, a confirmação do grande interesse pela fruticultura, porém, as representações sociais da floresta pelos assentados são, ainda, meras imagens e intenções que se concretizam como prática apenas no controle limitado dos comportamentos de não mexer na mata das reservas e nos animais silvestres.

Ibañez, citado por Sá (1996, p.42) diz que "é possível que um dado objeto social não seja representado (...) por determinado grupo social ou segmento da sociedade e que, não obstante, seus membros falem sobre tal objeto". Não se considera que os assentados da Fazenda Ipanema não tenham construído idéias e sentimentos referentes à floresta, pois eles já os traziam mesmo antes de se confrontarem com a mata da Fazenda. Porém, o dado novo foi a vivência direta com as questões que a floresta lhes colocou na realidade do assentamento. As novidades foram inúmeras, aliadas ao modelo de agricultura que já traziam e foi reforçado. Parece que a floresta já é representada, mas de formas contraditórias, não permitindo a concretização de seus saberes em fazer. 
Na figura 11 procura-se mostrar a articulação das representações sobre a floresta em torno dos núcleos temáticos identificados. Percebe-se que os temas "casa" e "animais silvestres" se afastam, assim como "reservas" e "projeto agropecuário". Eles não mantém uma afinidade, ou seja, no projeto para o lote estes assuntos são divergentes e não ocupam o mesmo lugar. Em um mesmo discurso a árvore não cabe no projeto agropecuário, porque o lote é pequeno e deve ser totalmente aproveitado com plantio agrícola ou pecuária; e cabe no projeto como quebra-vento, para madeira e até no pasto, porém não há ainda preocupação em providenciar esses plantios.

Entre os temas "casa" e "projeto agropecuário" existe uma afinidade. São temas convergentes, ou seja, convivem no mesmo espaço do projeto do lote, sendo, portanto, complementares. Igual relação é encontrada entre os temas "reservas" e "animais silvestres", mostrando que para os assentados a reserva é o lugar dos animais silvestres. São temas convergentes, complementares. Por conseguinte, estes temas não se incluem próximos à "casa" ou não se mantém inseridos no "projeto agropecuário".

Deve-se observar que em torno de cada núcleo circulam idéias novas dispersas, porque ainda não concretizadas na prática. Quando os temas são o "projeto agropecuário" e as "reservas", os sujeitos convivem com idéias que são contraditórias, mas que estão presentes nas representações de cada um, ao mesmo tempo, produzindo um saber contraditório e uma prática que se apoia nas velhas idéias, pois os dados novos carecem de objetividade.

Quanto às reservas, a idéia de preservar que vigora é a de "não tocar", mas ao lado dela já se admite "tocar", mas não se sabe como fazê-lo sem deixar de conservar. Mantém-se, então, o "não tocar".

$\mathrm{Na}$ questão da caça houve transformação nas representações e práticas, mas, hoje, apesar da idéia de preservar, há também a de manter os animais silvestres longe dos lotes. Consideram importante que eles estejam na mata, mas não sabe como mantê-los longe dos animais domésticos, mesmo no discurso daqueles que consideram ser possível conviver com eles, utilizando sistemas mais tecnificados de trato com os 


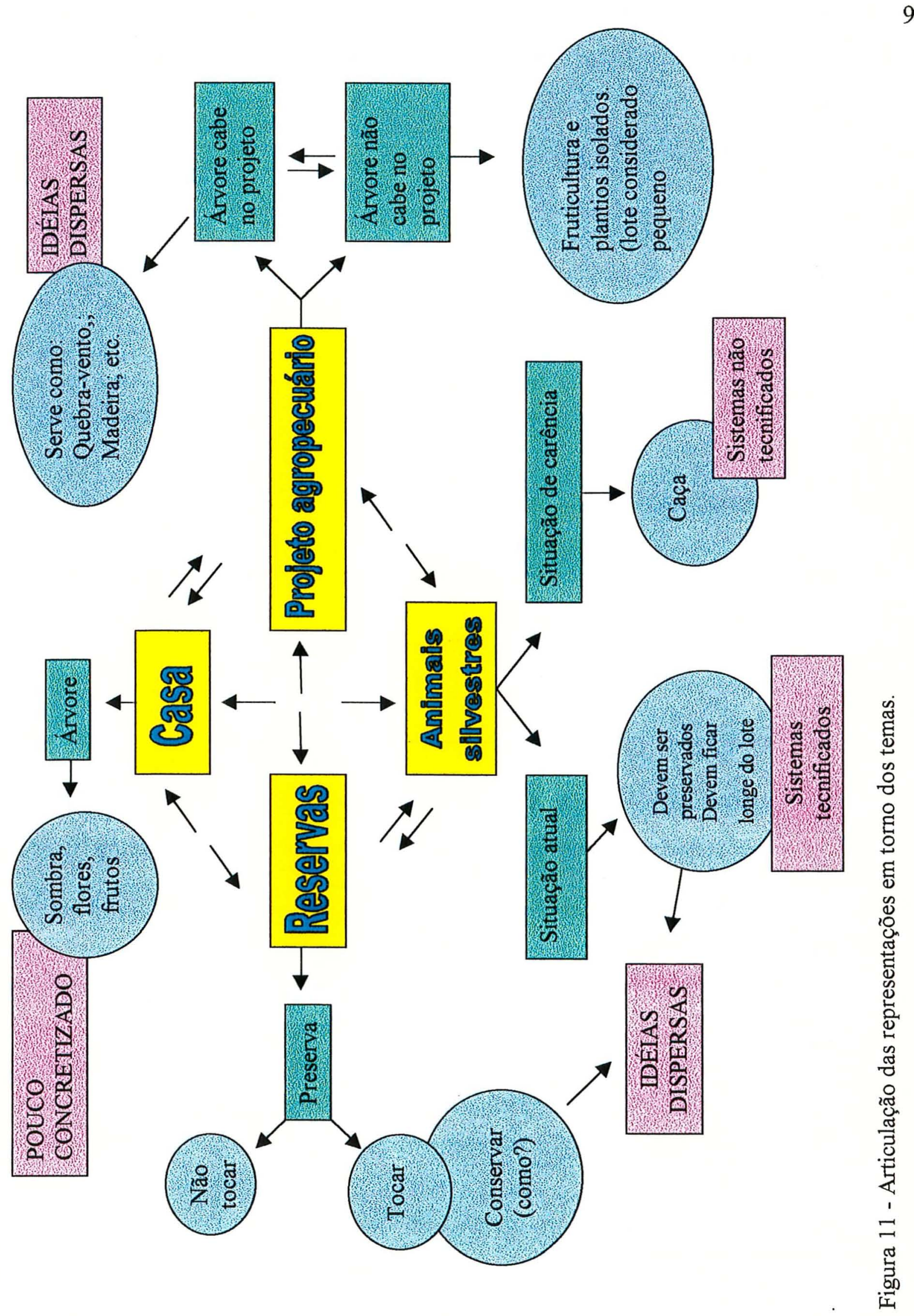


animais domésticos, como esses sistemas não estão disponíveis, a prática é de mantê-los longe. Essa realidade os faz permanecer presos a idéias ambíguas que tornam os elementos da floresta ora necessários e "bem-vistos" até mesmo dentro do lote, ora "malvistos" dentro de seus projetos, prejudiciais ao atendimento das suas necessidades mais urgentes.

A falta de apoio técnico e de recursos financeiros é que parece impedir que o saber sobre a floresta se amplie entre os camponeses assentados e se transforme em práticas que privilegiem os elementos florestais nos seus projetos de vida.

\subsection{6 $O$ papel das instituições na produção das representações sobre a floresta}

Após a ocupação, diversas instituições passaram a compor a história de vida dos assentados - o Estado, através de seus órgãos; as Universidades, alguns sindicatos de trabalhadores urbanos - isto é, o que eles chamam de apoios, e os que estão em posições antagônicas, com os quais têm que se confrontar constantemente através do MST.

O ITESP foi o órgão estadual que assumiu, após o reconhecimento do assentamento pelo INCRA, a parte do cadastramento, o planejamento global da área e, depois, a assistência técnica oficial no projeto.

Como o órgão acumulou as funções de acompanhamento técnico e gestor do projeto, as funções e os objetivos técnicos muitas vezes ficam confusos para os assentados, misturando expectativas e receios. De um lado, espera-se apoio, capacitação, assistência técnica, e de outro, eles são cobrados e avaliados pelos mesmos técnicos pela aplicação dos recursos financeiros oriundos do PROCERA e cumprimento de prazos para as atividades agrícolas planejadas. Além disso, os assentados passaram a conviver dentro da instância maior do assentamento - o Conselho de Representantes - com um ITESP, que acaba sendo a palavra final sobre os assuntos comunitários. Com isso, os técnicos passaram a desenvolver uma relação quase doméstica, onde questões pessoais e conflituosas do cotidiano do assentamento e até estratégicas do MST, misturaram-se com a relação técnico-institucional. 
Fica bem evidente na fala abaixo a complexidade da relação: apoio $\mathrm{x}$ cobrança, assistência x fiscalização.

Nossos próprios engenheiros são os próprios fiscais...não é? Até mesmo... você tem o seu lote aí...pode ter uma matinha rala aí no fundo do seu lote. Uma agüinha tal...uma coisa assim... se você começar a soltar animais ali dentro, ou até mesmo chegar ali e começar a desmatar é perigoso a pessoa ser punido, sabe? Com certeza... (Toinho)

Porém, com essa aproximação, o ITESP também conseguiu atrair o respeito e a simpatia dos assentados:

O ITESP eu sempre tive como o benfeitor da reforma agrária junto com o MST ele resolveu os problemas, de tentar buscar soluções....o Estado pode ter as falhas dele mas, aqui na Fazenda Ipanema tem $3, \ldots$ não vou dizer os melhores, mas entre os melhores (técnicos) do ITESP. A gente sempre teve bom diálogo, está sempre se afinando nas discussões aí. (João)

$\mathrm{Na}$ realidade o Instituto de Terras é que tem, realmente, brigado com a gente aí...Sempre eles taí, no dia-a-dia...no dia-a-dia nós tá junto aí...todas as segundas, periodicamente, nós temos reunião as horas datado. (...) Então, eu acho que hoje, uma das coisas que taí... tem que dar valor prá quem merece. $O$ trabalho que o DAF desenvolveu aqui dentro e tá desenvolvendo... (Toinho)

O Estado acaba sendo visto como o próprio benfeitor, retirando a força da organização autônoma deles e de toda história de enfrentamento com o próprio Estado, que demora a reconhecê-los. Confundem os esforços pessoais de alguns técnicos com o caráter de um Estado que não faz a Reforma Agrária e intervém nas organizações populares.

Os técnicos do ITESP, embora viabilizando alguns projetos para os assentados, reduzem a autonomia de sua organização. A mediação do ITESP no Conselho impossibilitou o surgimento de qualquer nova configuração para a organização do assentamento, pois ela acaba encobrindo os conflitos que seriam os únicos geradores de soluções criativas. 
Nas próximas falas percebe-se a demanda por maior assistência técnica, mas também, o reconhecimento do esforço dos técnicos em manter o serviço funcionando:

Eles não vêm assim numa exclusividade... bom, pelo menos até agora não veio no meu lote. Quando tem alguma coisa a gente comunica com eles e eles vêm e dá assistência... (Walter)

Eles ensinam, eles ensinam... até, até a assistência técnica deles tem sido razoável...Num vou dizer de pior ou de melhor, é razoável...Eu só fiquei sentido um pouco com a assistência técnica deles, não falando mal, mas vou falar a verdade, sobre esse projeto do plantio. Aí foi feito um projeto, foi eles que acompanharam tudo foi feito o levantamento por eles, só que na época que a gente táva plantando eles não veio ver se você táva plantando ou se plantou área adequada que era necessário ou não...não é? (Roberto)

Teria que ter no mínimo que fosse prá...se o DAF tivesse disponível, no mínimo quatro...não é? Tirando $O$ ' $T$ ' fora, porque $O$ ' $U$ ' é regional. Muitas vezes você precisa dele e ele não pode tá aí...Seria no mínimo quatro...não é? Tá tocando os dois, mais a gente sabe que é muito apurado. ...Eles mesmo reconhecem isso, não têm condições. (Toinho)

Nesta última fala Toinho está refletindo sobre a impossibilidade que existe hoje por um atendimento individual mais amplo, com mais técnicos envolvidos. Já José assume a falta de compromissos por parte dos assentados:

Porque até que eles pediram (para se proceder a coleta de solo para a análise)...que eles não tinha tempo de tá saindo de lote em lote fazendo isso. Até que eles exigiram da gente chegar em cada lugar da área, pegar um pouco de terra...não é? ...E se eles exigiram... e quase ... ninguém fez. Até que eles não têm culpa nisso aí, porque... eles também saírem de área em área por aí fazendo, isso é muita coisa. A gente também precisa mudar nessa parte também. (José)

A opção feita pelo Estado, com o aval do Conselho, quanto ao parcelamento da fazenda Ipanema em lotes individuais, eliminou a possibilidade de se implementar um modelo agrícola de caráter coletivo quanto à explotação do ambiente e a criação de agrovilas como forma de convívio social. Esta macro decisão foi determinada 
a partir de uma visão de vida rural calcada em um determinado modelo agrícola que exclui uma possível orientação para sistemas agrossilvopastoris mais amplos. Ele vai influenciar e dificultar as possibilidades de um planejamento ambiental mais global para o assentamento e tornar as relações sociais presentes cada vez mais individualizadas.

De qualquer forma, as áreas de floresta foram mais tarde delimitadas pelo ITESP e produziram um quadro de co-responsabilidade pelas reservas. Elas não foram traçadas para cada lote, mas para o assentamento. As ações dentro das reservas têm que passar pela fiscalização não só do governo (DEPRN) como do Conselho do assentamento. Porém, a concepção que orientou a demarcação das reservas não levou em consideração questões muito delicadas quanto ao manejo de fragmentos florestais, tais como: a destinação de áreas essenciais com a finalidade de criar corredores de fauna interligando as reservas legais do assentamento entre si com a floresta do IBAMA e o fragmento do ARAMAR; o respeito às áreas de preservação permanente nas áreas de cabeceiras de alguns córregos.

Quanto ao IBAMA, o contexto inicial de negociações tomou formas coercitivas no que se refere à preservação, não se transformando em forma educativa, mas em relações com base em uma política de boa vizinhança.

A respeito do Projeto ARAMAR, de modo geral, todos têm muitas dúvidas sobre o real objetivo do projeto e sobre a possibilidade de riscos de acontecer um acidente ambiental e vazamento de substâncias radioativas:

Olha, eu acho que...o mais dificil é o Aramar é ele mesmo. O Aramar é praticamente... até prá gente ter acesso lá é difícil, viu?... A rapaz... Ali tem coisa que eu não sei nem explicar o que que tem (risos)...viu? É um mistério... (Roberto)

Prá mim a Marinha não era prá tá localizada nessa área. Essa é a verdade. Uma das verdades seria essa...Primeiro que... Marinha tem que tá na beira de alto mar...não é? Que água que tem aqui? Como foi um jogo político, na época, ao qual trouxe a Marinha prá cá, pensando em envolver outras firmas grandes pro município, e acabou não acontecendo isso...E que tá aí... prá nós, em momento algum seria bom...sabe disso...não é? Tem essas 
áreas deles ai que... por falta de.. (...).de qualquer uma familia aí sem ter um conhecimento... (Toinho)

Há medo de confrontos com os navais e o respeito à cerca é sempre presente:

...que teve uma época, alguns dias atrás aí, os naval tavam correndo a cerca de ponta a ponta. Teve até tiroteio lá... eles fazendo alvo lá. Eles não querem nem que se aproxima da cerca. (Roberto). 


\section{CONCLUSÕES}

A maioria dos novos camponeses da Fazenda Ipanema quando a ocupou não tinha larga experiência rural, principalmente na condição de pequenos proprietários. Porém, alguns apresentaram conhecimentos apurados sobre o trato com a terra e o relacionamento com a natureza: reconhecimento de árvores nativas próprias para a construção de habitações, indicação de locais adequados para abertura de poços através do uso de forquilhas (radiestesia), prática na utilização da tração animal no preparo da terra, conhecimento sobre as épocas mais favoráveis para o corte de madeiras e plantio de sementes e mudas a partir dos períodos lunares, identificação de plantas medicinais da flora local etc. Esses sujeitos cumpriram um papel de modelo desde o acampamento, na orientação sobre a derrubada de árvores $e$, posteriormente, nas atividades produtivas. Eles não apareceram necessariamente como liderança, mas como referência para várias práticas do cotidiano do acampamento. Algumas vezes esses personagens eram coordenadores de brigadas ou de grupos de trabalho.

As lideranças (militantes) cumpriram outra função na constituição de novos saberes. No início, através de uma organização rígida e punitiva dos desvios, trouxeram para o coletivo a exigência de não derrubar indiscriminadamente a mata, além de coibir o abate da fauna nativa na forma de caça. Foi conformado, então, um saber ainda externo para muitos, que nem sempre se transformou em valor pessoal, mas que produziu algumas concepções sobre 'preservar'.

'Preservar' era 'não tocar'. Transgredir essa norma significava ser punido de alguma forma.

Enfim, a maioria dos assentados consideram que o lote não é lugar para a floresta, uma vez que ela já está contemplada fora deste. 
O elemento arbóreo aparece com funções limitadas de embelezamento e sombra em pequena escala. Em apenas um caso se vislumbrou associar árvores a um projeto de pecuária.

O pressuposto de que a participação em instâncias decisórias conformaria um saber diferenciado sobre a floresta se confirmou apenas no que se refere a uma maior preocupação com os mananciais de água e proteção da fauna. Porém, será nos 'coletivos' independente de participarem ou não de instâncias decisórias, que aparecerão relatos que denotam um valor já construído internamente para com a mata, que vem da 'consciência', como eles dizem. De qualquer forma, circula, entre todos, um saber sobre a necessidade de preservar que, com se viu, inicialmente significava 'não tocar' e hoje articula-se com as idéias disseminadas principalmente pela ESALQ, segundo os relatos, de 'conservar', embora eles não utilizem esse termo.

Quanto ao pressuposto de que a prática agrícola na Área 1 ou 2 colocaria os camponeses em confronto diverso com a natureza e isso interferiria nas representações sobre a floresta, não se concretizou. O que predomina nas representaçães não é o projeto técnico que o ITESP delineou, mas os sonhos de cada um. Independente da Área 1 ou 2 todos querem um projeto agropecuário, com mais ênfase na agricultura ou na pecuária dependendo das condições objetivas do lote. $\mathrm{E}$ a questão florestal aparece para todos dentro desse sonho comum. A fruticultura, por exemplo, surge nas intenções de parceleiros de ambas as áreas.

Quanto ao pressuposto de que uma prática de trabalho coletivo ou individual determinaria saberes diferentes sobre a floresta também não se concretizou. Os projetos agropecuários se desenvolvem e têm pretensões de se desenvolver diferentemente conforme o tipo de trabalho, mas isso não modifica a representação da floresta.

Para os 'coletivos' três temas aparecem no projeto agropecuário: avanço tecnológico; competitividade no mercado e necessidade de organização. Porém não aparece um modelo de agricultura associado à floresta. 
Há um imediatismo nas perspectivas de futuro tanto dos 'coletivos' como dos 'individuais' que não comporta o elemento arbóreo e a mudança de um modelo tradicional de agricultura para um modelo sustentável, embora muitos expressem preocupações com isso. Esse imediatismo é explicado, por eles próprios, como urgência em consolidar o assentamento diante da opinião pública. Além disso, há a necessidade de sobreviver e a vontade de melhorar as condições de vida. Para o MST a forma cooperativada de organização será a única a garantir a manutenção dos assentados e a continuidade da luta pela Reforma Agrária. Por isso o imediatismo também se faz presente, não propondo formas agrossilvipastoris.

Os camponeses que participam das instâncias decisórias, independente de trabalharem coletivamente ou individualmente, demonstram terem se apropriado de algumas informações técnicas, mas isso não modifica muito as representações da floresta, porque o modelo de agricultura apresentado pelos técnicos é o tradicional. Esse modelo atende ao imediatismo que os camponeses se colocam, mas que está em contradição com suas reais possibilidades e com o desejo de muitos de perseguirem um outro desenvolvimento rural, como no discurso do MST. Além disso, o modelo tradicional difundido traz com ele a idéia de progresso que já está impregnada no imaginário social. A floresta tem, na História do Brasil, uma representação de natureza selvagem e o progresso no meio rural se desenha como uma natureza cultivada, campos limpos, terra coberta por monoculturas a perder de vista.

Estas representações antigas facilitam a penetração de um discurso desenvolvimentista que apresenta resultados econômicos mais imediatos, objetivando desta forma, a idéia de progresso e sucesso que pretendem divulgar. Porém, esse imaginário não se impõe e persiste de forma homogênea e como pura repetição. Mesmo porque, o próprio modelo possui contradições que se tornam insuperáveis para pequenos produtores descapitalizados.

Esse modelo de desenvolvimento predatório, como se observa na história do Brasil, no que se refere às florestas, gera riquezas, miséria, tecnologias avançadas e destrutivas do meio ambiente. Porém, para sua própria sobrevivência, ao mesmo tempo 
cria mecanismos para controlar os estragos que provoca, e dessa forma, produz abertura para o aparecimento de novos saberes nas suas rachaduras ou inconsistências.

Um dos assentados que participa de experiências de trabalho coletivo e de instância decisória no assentamento, em determinada fala, explicita sua visão de floresta que mistura idéias antigas sobre o lugar das florestas em recantos distantes, selvagens e com uma função extrativista, incompatível com projetos agrícolas, ao mesmo tempo que considera a importância da floresta na manutenção da biodiversidade e na proteção da fauna.

Outra questão que se percebe ter origem em passado distante e se refaz nas condições sociais atuais é a idéia dos prejuizos trazidos pelo eucalipto. Muitos produtores não querem nem ter o eucalipto perto para que não resseque suas terras. Não perceberam que o que produziu o cenário ressequido de enormes extensões de terra plantadas com eucalipto não é a árvore isoladamente ou em um plantio adequado, mas foi o uso que foi feito dela, uma essência exótica, introduzida no Brasil com fins econômicos, como monocultura, eliminando consideráveis extensões de terra com cobertura florestal nativa.

Como no modelo teórico proposto, os velhos saberes não são substituídos pelos novos, nem se reproduzem infinitamente. Os contextos se refazem e as significações tomam formas que se ancoram no passado, mas, na medida que incorporam a novidade do presente, adquirem sentidos novos. Quando o conhecimento velho está marcado somente por impressões ou imagens não conectadas com a experiência imediata, dificultam a ancoragem dos dados novos. Quando estes dados novos, mal ancorados, não se transformam em práticas concretas, dificultam o processo de objetivação desses dados.

Enquanto os novos saberes que circulam sobre a floresta atualmente no assentamento não produzirem práticas concretas em relação a um projeto de vida que contemple a floresta, as representações serão contraditórias e pouco significativas na orientação do cotidiano.

A pesquisa realizada contribuiu para a compreensão de que as representações da floresta se produzem nas situações de vida e que qualquer saber 
realizador, isto é, transformador de valores e ações, tem na solidariedade grupal um caminho privilegiado. Medidas punitivas para modelar o comportamento dos grupos e pessoas produzem resultados práticos imediatos, no sentido de eliminar comportamentos indesejáveis, mas não constituem comportamentos persistentes, calcados em valores construídos, que não necessitam de controle externo.

Para os sujeitos pesquisados havia um contexto anterior à ocupação, quando eles ainda não se constituíam como grupo; um contexto de acampamento, quando a vida comunitária foi intensa para resistir às tentativas de despejo e às necessidades advindas da carência inicial de alimentos e moradia; e um contexto atual, momento que o grupo foi assentado em lotes definitivos.

Os sujeitos tinham um projeto de vida antes de se constituírem como grupo. Com a luta comum e sob a influência do MST, tiveram que se organizar, receber informações, compor e recompor os projetos iniciais. Entraram em contato com universidades e órgãos governamentais e não-governamentais. A partir dos conflitos locais e conhecimentos adquiridos nas práticas desenvolvidas, redesenharam os sonhos que tentam agora concretizar.

Em todos esses contextos o grupo social desenvolveu solidariedades, com base no sentido da luta comum, e adestramentos, advindos da necessidade do MST de direcionar a ocupação e dos órgão estatais de controlarem a ação de expansão do espaço ocupado e de preservação da mata instituída como FLONA.

O estudo sobre as representações da floresta concluiu que o saber dos assentados sobre esse tema é ambíguo e contraditório. Porém concluiu, ainda, que existem conhecimentos dispersos circulando entre os assentados. Há desejos de realizar ações relacionadas à fruticultura, ao uso sustentado das reservas e ao paisagismo.

Outra intenção importante que apareceu entre eles, mas também encontrase dispersa, é quanto à recuperação das margens das represas. Foi, ainda, constatado interesse por parte de muitos assentados quanto à práticas alternativas de controle de pragas e doenças a fim de evitar o uso de agrotóxicos. 
Quanto à agricultura praticada, já existem ações sendo implementadas que consideram a diversificação e rotação de culturas, carecendo, entretanto, de informações sobre a possibilidade da incorporação do elemento arbóreo em um sistema agrossilvicultural mais sustentável.

Apesar dos conhecimentos estarem dispersos, o grupo social já se constituiu como uma comunidade, com conflitos, divergências, diferentes projetos, mas um grupo que tem uma história comum. $\mathrm{O}$ elo entre as pessoas torna possivel o acesso dos técnicos à comunidade. Esta apresenta-se aberta para as novidades e há circulação dos conhecimentos, existindo necessidade, no entanto, de uma organização mais autônoma e democrática no assentamento que possa direcionar as ações conjuntas e individuais para um projeto que contemple a floresta. Esses projetos precisariam de subsídios financeiros e apoio técnico que as instituições compromissadas com a reforma agrária teriam que prover.

Como a intenção de realizar esta pesquisa foi de dar apoio às ações educativas junto aos assentados voltadas à incorporação do elemento arbóreo, as recomendações que se seguem, baseadas nas reflexões anteriores, devem levar a uma primeira premissa de que qualquer intervenção técnico-educativa não pode perder de vista a história do grupo onde irá intervir. Os saberes transformadores são aqueles apropriados pelos grupos e que podem ser por eles ancorados e objetivados.

Ao longo da pesquisa pôde-se observar várias referências, idéias e conhecimentos advindos de relacionamentos anteriores com estudantes e professores da ESALQ Porém, ficou claro que as ações realizadas, por melhor que fossem as intenções e esforços de alunos e professores, não conseguiram produzir mudanças efetivas no grupo social. Talvez por não ter existido um plano de ação global (para todo o assentamento) que partisse da história coletiva e seus conflitos. A reconstrução da história com o grupo permitiria a apropriação, por eles, de um conhecimento produzido entre eles, mas sobre o qual ainda não puderam refletir coletivamente.

Freire $(1989$, p.69) diz que: 
"a classe trabalhadora tem dois direitos, entre muitos outros fundamentais. Primeiro, conhecer melhor o que ela já conhece a partir da sua prática. (...) o segundo direito é o de conhecer o que ainda não conhece, portanto, de participar da produção do novo conhecimento."

Mais adiante, o autor acrescenta:

"Se a classe trabalhadora não teoriza a sua prática é porque a burguesia a impede de fazê-lo. Não porque ela seja naturalmente incompetente para tal. Por outro lado, o papel do intelectual revolucionário não é o de depositar na classe trabalhadora, que também é intelectual, os conteúdos da teoria revolucionária, mas o de, aprendendo com ela, ensinar a ela."

Outra questão que deve ser refletida pelas universidades que pretendam um trabalho de educação e planejamento ambiental é que uma consciência ambiental não é transformadora se não se constituir em consciência social, isto é, não há mudança de valores e comportamentos em relação ao meio ambiente sem luta pela mudança nas relações sociais. Não é possível esquecer duas dimensões importantes da educação ambiental: a política e a ética. É mais uma vez Freire (op. cit.) que, lembrando Gramsci, ensina:

'É necessário reinventar o poder. (...) Nessa reinvenção do poder, ou as massa populares têm uma participação ativa e crescentemente crítica no processo de aprendizagem de serem críticas, ou o poder não será reiventado."

Para que haja educação é preciso participação e compromisso efetivo de educandos e educadores no processo de aprendizagem e ação coletiva.

A pesquisa apontou para núcleos temáticos em torno dos quais um trabalho educativo no assentamento da Fazenda Ipanema poderia recuperar o saber da comunidade e problematizar situações ainda não refletidas. Dessa forma, seria possivel 
realizar um diagnóstico e um planejamento participativos para o desenvolvimento de projetos comunitários e individuais.

Assim, as intervenções técnicas das universidades nos assentamentos não podem deixar de ser educativas, não no sentido da difusão de conhecimentos prontos, mas da construção conjunta de novos conhecimentos.

Se por um lado as universidades falham no seu compromisso com a realidade dos assentamentos no que se refere à educação ambiental, os órgãos de pesquisa falham porque também fazem investimentos pontuais na questão da reforma agrária principalmente no tema florestal.

Esta pesquisa retrata a situação de centenas de assentamentos rurais que encontram-se sem apoio dos órgão de pesquisa voltados à questão florestal que contemple a pequena propriedade. Percebe-se que não existem conhecimentos adaptados para o camponês que possam ser apropriados em forma de tecnologias, dentro de uma visão de totalidade das propriedades, das microbacias, dos assentamentos e das regiões. Os sistemas agrossilviculturais disponiveis não dão conta das especificidades das questões existentes nos assentamentos tais como: produção para a subsistência e mercado; necessidade de estoque madeireiro a fim de suprir as demandas internas e não permitir pressões futuras sobre a mata existente; tamanho limitado da propriedade que pode provocar o uso indiscriminado das matas nativas sem o conhecimento de outros modelos de agricultura e de uso sustentável das reservas; necessidade de tecnologias que preservem a cultura camponesa de criação de pequenos animais para subsistência sem eliminar os animais silvestres predadores; necessidade de recuperação das reservas pelo coletivo; urgência de um modelo agrícola apropriado à produção camponesa que garanta a biodiversidade e a saúde da comunidade.

Fica mais séria a questão da intervenção técnico-educativa ambiental nos assentamentos quando ela se refere aos órgão governamentais que teriam essa função específica dentre outras.

Algumas falas registradas pela pesquisa mostram a percepção que os assentados têm da responsabilidade de órgãos governamentais voltados para o meio 
ambiente, em especial o IBAMA. Existe uma expectativa com relação ao apoio institucional do IBAMA, não só quanto ao empréstimo de máquinas e equipamentos ou para a abertura de aceiros que protejam a FLONA, mas quanto a questões mais amplas, de cunho educativo, sobre a preservação da flora e da fauna e sobre a possibilidade de projetos conjuntos, envolvendo Associações e o Conselho de Representantes do Assentamento da Fazenda Ipanema.

Propondo aos assentados projetos com a característica de 'florestas sociais', o IBAMA poderia gerar empregos para os jovens, além de produzir um regime de parceria com os assentados em relação ao manejo de muitas áreas da FLONA hoje inviabilizadas.

Esses projetos propiciariam uma gestão coletiva de diversas áreas da FLONA, melhoraria as condições de vida da comunidade e criaria um espaço rico para aprendizagens conjuntas.

Partiu dos próprios assentados idéias como: plantio de palmito (ou espécies similares como a pupunha) dentro da mata; e plantio de eucalipto nas divisas do IBAMA. Essa última sugestão resolveria o problema do plantio de árvores no entorno da floresta, produzindo o efeito de bordadura necessário a sua preservação.

Houve um discurso interessante de uma assentada que expressou a percepção da falta de comprometimento do IBAMA com a comunidade. Ela disse: "O eucalipto do IBAMA vai ficar bom prá quem é dono". E quem é o dono?

Nem todos conseguem apreender que os recursos da FLONA são públicos, portanto, da responsabilidade e para beneficio de todos. A questão não é a ausência de informações circulando entre os assentados, mas sim, pelo tipo de mensagem que o IBAMA lhes transmite, apresentando a FLONA como algo de interesse privado que está sob o controle efetivo de uma burocracia que se investe dos poderes de 'dono'.

Essa questão traduz que a política de boa vizinhança do IBAMA não é suficiente para gerar uma consciência cidadã. 


\section{ANEXO A \\ PROJETO ATUAL DE PRODUÇÃO DO ASSENTAMENTO (DINÂMICA DOS DESENHOS)}

Esta dinâmica foi realizada em diferentes locais do assentamento, a saber:

1- Área 2, no dia 09 de novembro de 1996, com 11 participantes;

2- Vila Smith, no dia 23 de janeiro de 1997, com 16 participantes

3- Área 1, no dia 06 de fevereiro de 1997, com 17 participantes

4- Grupo 9, no dia 09 de março de 1997, com 15 participantes

5- Vila Mursa, no dia 23 de março de 1997, com 16 participantes

Era pedido a cada participante que representasse o seu sonho num desenho, ou seja, que o desenho registrasse as principais expectativas de realizações nos lotes definitivos. Após o desenho, cada participante era convidado a apresentar de forma suscinta o seu trabalho gráfico.

A dinâmica consistia em fazer com que cada um revelasse o seu sonho individual (familiar) ao grupo. Ao tornar públicas suas expectativas, cada um passaria a compartilhar e a se comprometer com o outro.

Apesar de terem participado da atividade de desenho 75 pessoas, somente 62 se propuseram a falar do seu sonho. Algumas pessoas se retiraram dos grupos após o término de seus trabalhos. De acordo com o quadro X, falaram sobre seus desenhos 36 homens $(58,1 \%)$ e 26 mulheres $(41,9 \%)$. Considerando-se que no assentamento vivem 148 famílias presume-se que a participação foi bastante significativa.

A análise deste quadro geral nos indica:

- O sonho mais importante explicitado nas falas foi a construção da casa definitiva $80,6 \%$, equivalente a $77,7 \%$ dos homens e $84,6 \%$ das mulheres. Existem casos em que o assentado já mora em sua residência definitiva, o que pode ter ocasionado a não unanimidade do resultado das resposta; 
- Na análise da expectativa pelos projetos de produção percebe-se que a fruticultura é a atividade mais desejada: $77,4 \%$ dos participantes - para os homens: $72,2 \%$ e para as mulheres: $84,6 \%$. A fruticultura aparece como maior expectativa em todas as áreas do assentamento. Isso não significa que o plantio de frutas venha a ser a atividade mais forte economicamente na fazenda. Os dados apenas indicam que a maioria dos assentados têm desejo de plantar algum tipo de fruta em seus lotes, seja como atividade produtiva ou apenas para o autoconsumo familiar.

- A segunda atividade declarada como desejo a ser implementado é a pecuária bovina. Nota-se que em alguns casos, no relato do desenho aparece apenas a pastagem o que pode significar tanto a criação de bovinos como também de eqüinos, caprinos ou ovinos. Entretanto, percebe-se que a bovinocultura se sobressai como atividade pecuária mais importante em todas as áreas do assentamento e desejada tanto por homens (61\%) quanto por mulheres $(50 \%)$.

- Os projetos que se apresentam em terceiro e quarto lugares de interesse são a lavoura branca de subsistência e a criação de aves, em especial, galinha para postura e corte. No item lavoura branca foram agrupadas todas as indicações pelo plantio de milho, feijão, arroz e mandioca. 40,3\% das pessoas colocaram em seus desenhos alguma dessas culturas - $41 \%$ entre os homens e $38,5 \%$ entre as mulheres. Com relação a avicultura, esse percentual é de $38,7 \%$ no total dos participantes, $27,7 \%$ para os homens e $53,8 \%$ para as mulheres, o que pode significar uma tendência à opção feminina pelo trato com pequenos animais cabendo aos homens o trabalho mais pesado no preparo da terra e com o gado. É evidente que isso é só uma tendência existindo mulheres cadastradas que almejam, como atividade principal a bovinocultura. Como exemplo a $\mathrm{Sr}^{\mathrm{a}}$ Magda, da área 2 , quadro $\mathrm{Y}$, que diz querer plantar frutas ao redor da sua casa apenas para o consumo doméstico.

- A seguir aparece 'outros projetos' agrícolas com $27,4 \%$ da preferência geral, ficando muito equilibrado o interesse entre homens e mulheres em todas as cinco áreas. Por 'outros projetos' foram agrupadas a cultura do café (cerca de $40 \%$ das indicações) e as 
declarações que não especificaram o tipo de plantio. Alguns se referiram a culturas que poderão apresentar melhor demanda no mercado em momentos futuros.

- Em torno de $18 \%$ do interesse total estão a suinocultura com $19,3 \%$ e a piscicultura com $17,7 \%$. O desejo de criar porcos está pulverizado por todo o assentamento e na proporção entre homens $(13,9 \%)$ e mulheres $(26,9 \%)$ as mulheres têm o dobro da preferência. Quanto à criação de peixes, a opção masculina por esta atividade é de $25 \%$, contra apenas $7,7 \%$ nas mulheres. Observa-se que no Grupo 9 por não haver muita disponibilidade de água tal desejo está ausente.

- Plantio de hortaliças é uma atividade mais específica da área 2 pelas próprias condições agroambientais. Nessa área a horticultura aparece com $50 \%$ do desejo dos participantes. $\mathrm{Na}$ proporção entre homens e mulheres tem-se: $80 \%$ para os homens e $28 \%$ para as mulheres.

- Próximos aos $10 \%$ tem-se as atividades de criação de cavalos - $8,0 \%$ e ovinos e caprinos com $9,6 \%$ do total geral. O cavalo surge como meio de transporte e força motriz para implementos agrícolas de tração animal. Nota-se uma tendência a uma opção pela adoção de tecnologias modernas e uso de tratores para o cultivo da terra. Daí ser baixa a opção pelo uso de cavalos.

- Por fim, surgem outras atividades como a criação de bicho da seda, mais localizada na Vila Smith onde existe um pequeno grupo de assentados que estão se organizando para esta atividade. Quanto à criação de rã, o depoimento foi um caso isolado na Vila Smith.

- Passando-se para a questão da arborização, sente-se como muito fraca a vontade de realização desta atividade - uso do elemento arbóreo. Apenas 9,7\% dos participantes totais abordaram esta perspectiva. $\mathrm{Na}$ área 2 as mulheres colocaram em suas falas e desenhos o desejo de fazerem uma arborização no entorno de suas casas - $42 \%$ das participantes do grupo. Na Vila Smith apenas um homem e uma mulher expressaram esse desejo.

- Arborizar as cercas e divisas foi também pontual na área 2 e na Vila Mursa/Filadélfia. Plantios comerciais, (ou seja, um talhão com a finalidade econômica) apareceram apenas dois casos na área 2 e um caso na Vila Smith. 
- Quanto ao plantio com vistas a um enriquecimento da flora nas área de reservas, novamente a área 2 expressou uma diferenciação surgindo três pessoas entre as doze presentes no grupo que manifestaram tal consciência ou preocupação. Um caso isolado apareceu na área 1 .

- Por esse quadro podemos entender que o projeto destes assentados é plenamente voltado para um modelo agropecuário de subsistência, com comercialização dos excedentes. A não existência de uma preocupação com a utilização do elemento arbóreo pode estar relacionada com esta opção por esse tipo de modelo agrícola. Pode ter relações também com a falta de informações técnicas sobre vantagens e beneficios quanto a adoção de sistemas agrossilviculturais. Pode estar associada também a falta de assistência técnica florestal, ao tamanho do módulo da terra e outros fatores que aqui não são analisados.

- Um item que apareceu de forma pontual diz respeito à utilização racional das reservas legais do assentamento. Apenas dois homens da área 2 e um da área 1 representaram esta possibilidade. Em conversas informais após esta dinâmica diversos assentados manifestaram desejos de utilizá-las porém após a fixação definitiva nos lotes. Por isso, é provável que não tenha aparecido nos desenhos por se tratar de ações incertas e futuras, portanto, fora do sonho imediato dos assentados.

\section{CONCLUSÃO:}

Conforme consta nos objetivos desta dinâmica, o essencial era explicitar o sonho ou o projeto dos assentados da Fazenda Ipanema.

Os sonhos expressos nos desenhos apontam para um projeto de uma agropecuária onde o plantio de frutas e a criação bovina foi bastante significativa. Esses projetos não estão desvinculados das representações sociais produzidas nesses cinco anos após a ocupação, e também, do relacionamento com as diferentes instituições presentes no assentamento. 


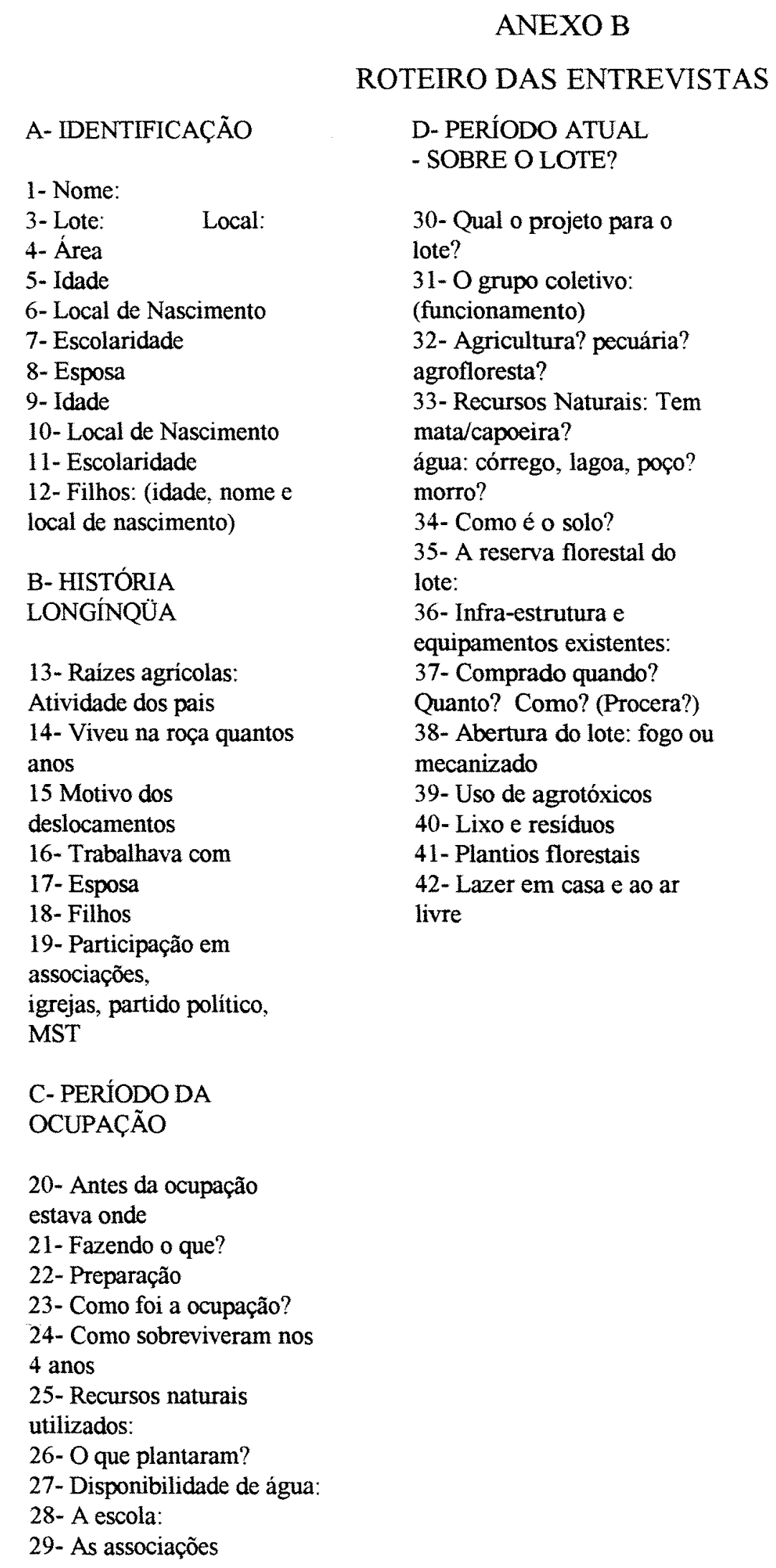


ANEXO C

QUADRO INICIAL DE ANÁLISE DAS FALAS

Quadro de Respostas $\quad$ chaud t.doc
\begin{tabular}{|c|l|c|c|c|}
\hline$N^{\circ}$ & Nome & Lote & Area & Lideranca no Assentamento \\
\hline 14 & Waiter & & - & \\
\hline
\end{tabular}

Identificaçăo Origem

\begin{tabular}{|c|c|c|}
\hline Temas & Item & Resposta \\
\hline Nome & & Walter \\
\hline Idade & & $\$ 2$ \\
\hline Local nascimento & & Mococa SP \\
\hline Escolaridade & & $8^{4}$ do $l^{*}$ graul \\
\hline Tamanho da familia & & 5 \\
\hline Cônjuge & & Nome retirado \\
\hline Filhos & & - Nomes retirado \\
\hline Outros & & \\
\hline $\begin{array}{l}\text { Moradia antes da coupação - } \\
\text { Local }\end{array}$ & & Sào Panlo \\
\hline $\begin{array}{l}\text { Morada antes da ocupaça - } \\
\text { Tempo }\end{array}$ & & 41 \\
\hline Profissóes anteriores & & Motorista \\
\hline Vida na roça & & 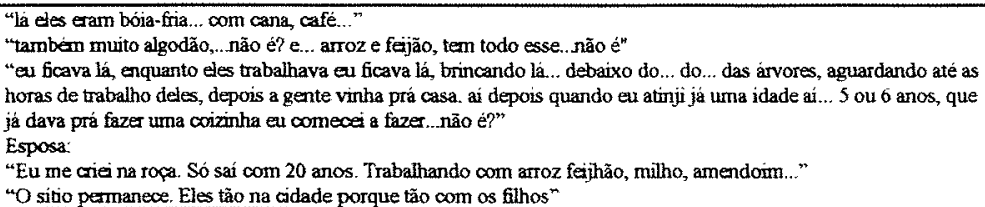 \\
\hline Saida da roça & & 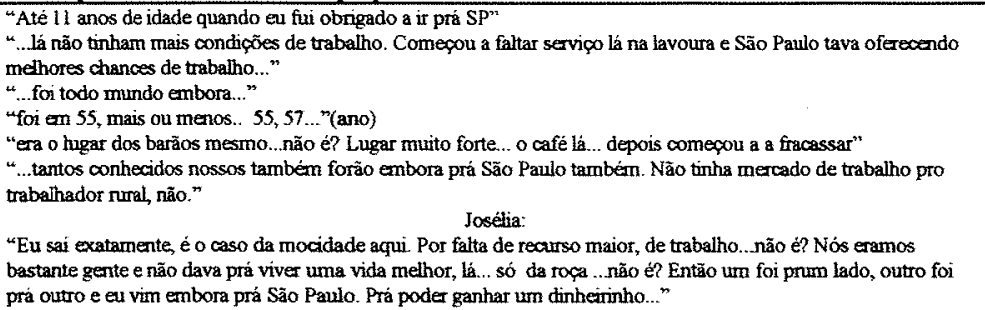 \\
\hline
\end{tabular}

\begin{tabular}{|c|c|c|}
\hline Temas & Item: & Resposta \\
\hline $\begin{array}{l}\text { Condicoes que o levaramn a } \\
\text { participar da ocupacāo }\end{array}$ & A-1 & \\
\hline Preparativos da ocupacão & A & 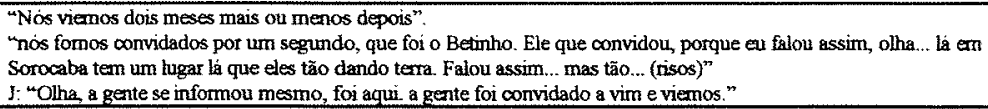 \\
\hline Moradia & $B$ & 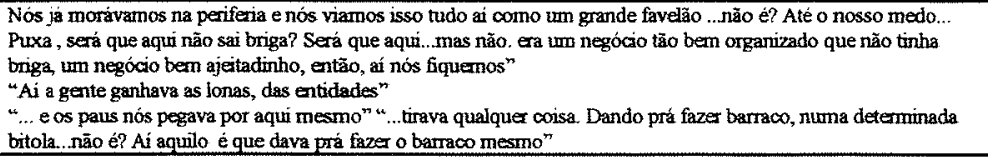 \\
\hline Natureza - Recursos. Naturais & $\mathrm{C}$ & Tulha muita madera \\
\hline Apoios & $\mathrm{C}+1$ & $\begin{array}{l}\text { nós tivemos ajuda, inclusive da igreja católica e diversas entidades } \\
\text { annigos também nos ajudou bastante } \\
\text { O próprio governo cornexou a mandar a cesta básica } \\
\text { Uns } 5 \text { meses mais ou menos. Depois contaram }\end{array}$ \\
\hline Alimentaça & $D$ & $\begin{array}{l}\text { Melancis, arroz, fejião, milho, abobora, milho verde... } \\
\text { Parte era vendido e parte era nosso próprio consumo }\end{array}$ \\
\hline Água & $E$ & $\begin{array}{l}\text { tinha um pequeno... riachozinho } \\
\text { tinha as minas também } \\
\text { as vezes passava meio dia na fila prá pegar um balde. Depois a prefétura comecou a vim, um, dois carninhão prá } \\
\text { trazer a água. }\end{array}$ \\
\hline Tecnologia & $\mathrm{F}$ & $\begin{array}{l}\text { Nào se qual foi a forma que o Sandro e a Deise conseguiu...não é? a gente nâo ficou sabendo, se foi eles que } \\
\text { perimam ou se foi iniciativa do proprio ltesp } \\
\text { nós precisávamos, de trator e implemento para o nosso trabalho, porque era muito dificultoso aqui... a... nós } \\
\text { trabalhávamos ai no braço... não tinha nem condição... não é? devido a.. muita terma e nós precisariamos de } \\
\text { tratores. }\end{array}$ \\
\hline
\end{tabular}




\begin{tabular}{|c|c|c|}
\hline Onganizaçấ & $\mathrm{H}$ & 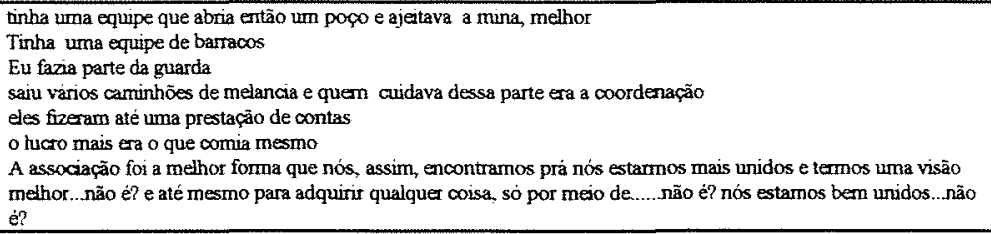 \\
\hline Educaçầo & 1 & 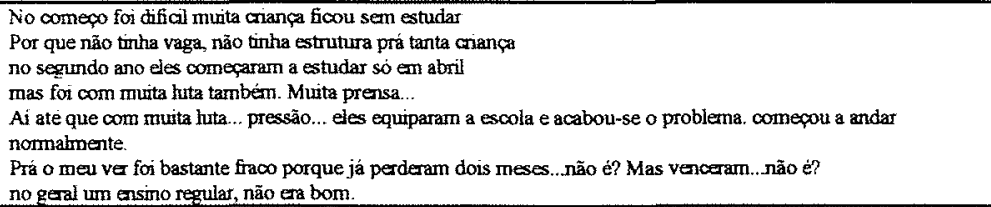 \\
\hline Expectativa aspração/sonho & $J$ & $\begin{array}{l}\text { E que nós tinha vontade mesmo de... voltar a lavoura, agricultura e nos vimos que essa seria a ultuma... o único } \\
\text { meio, nảo tinha outro meio...não é? }\end{array}$ \\
\hline Resistência & $\mathrm{K}$ & Comecenos a plantar, produzu com muta dificuldade por que nãom tinha a ajuda de ninguem \\
\hline Avaliaçấo & $\mathrm{K}+1$ & 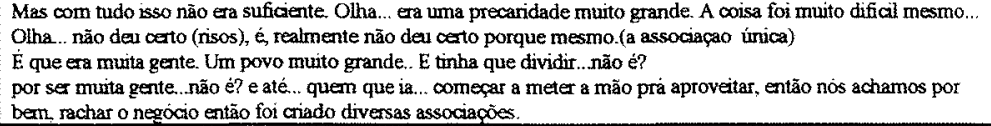 \\
\hline Discrimunacie & $\mathrm{K}+2$ & as professoras não. O povo no lugar em geral sim \\
\hline
\end{tabular}

\begin{tabular}{|c|c|c|}
\hline Ternas & Item & \\
\hline $\begin{array}{l}\text { Projeto } \\
\text { Sonho } \mathrm{p} / \mathrm{o} \text { lote }\end{array}$ & $\mathrm{L}$ & 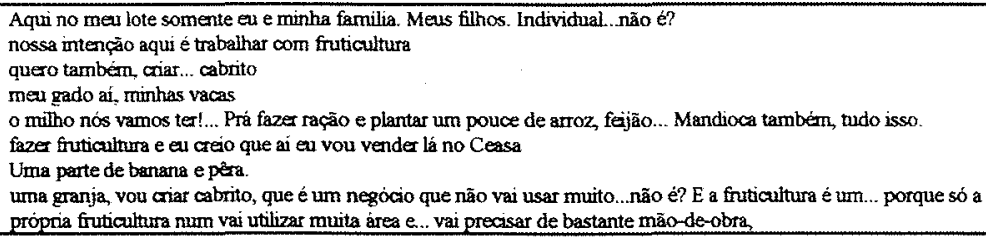 \\
\hline Sonho pi o assent & $M$ & \\
\hline Moradia & $\mathrm{N}$ & \\
\hline Rec Nat disponiveis & $\mathrm{O}$ & $\begin{array}{l}\text { Passa córego, tem diversas nascentes aqui com bastante água. } \\
\text { A terra é uma das melhores. Então eu tive sorte. Bern protegido, com aguádas, né }\end{array}$ \\
\hline Rec técricos desporiveis & $\mathrm{P}$ & $\begin{array}{l}\text { Ten esse barraco...tem ai a nossa carroça que muito nos ajuda, nossos animais... } \\
\text { Vacas, porco, bastante galinha... nós temos perí. nós temos cabrito...cavalo } \\
\text { olha de São Paulo praticamente nós não viemos com nada... }\end{array}$ \\
\hline Rec. que pretende adquirir & $Q$ & \\
\hline $\begin{array}{l}\text { Reserva - Mata } \\
\text { Plantios forestris }\end{array}$ & $\mathbf{R}$ & 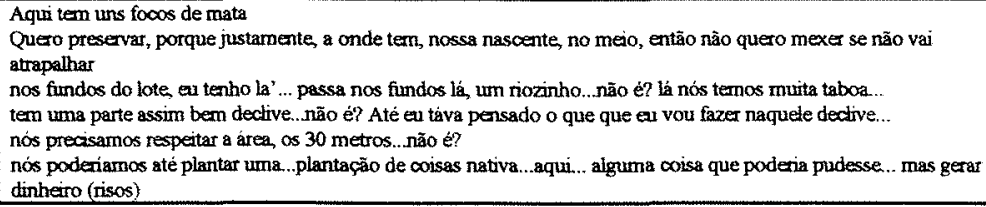 \\
\hline Dificuldades & $\mathrm{s}$ & 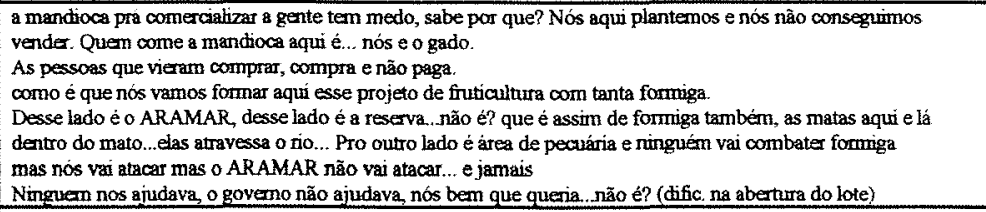 \\
\hline $\begin{array}{l}\text { Solupões } \\
\text { encontradas }\end{array}$ & $T$ & 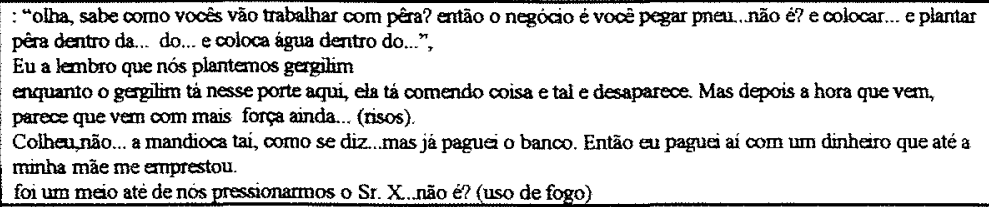 \\
\hline Lazer & $\mathrm{U}$ & prá nós é a igreia porque outra diversăo nâo existe \\
\hline Expectativas para os filhos & $\mathrm{V}$ & $\begin{array}{l}\text { já fiz esse projeto de cercar prá criar galinha, justamente, pros meas filhos, não e nem prá mim, seria pros mets } \\
\text { filhos prá eles terem uma renda } \\
\text { fruticultura num vai utilizar muita área e... vai precisar de bastante mão do-obra }\end{array}$ \\
\hline Relação com os tecricos & $W$ & $\begin{array}{l}\text { nós temos, então, reurnà̃o com eles periódicamente do Conselho... } \\
\text { eles não vêm assim numa esclusividade... bom, pelo menos até agora não veio no meu } \\
\text { quando tern alguma coisa a gente comunica com eles e eles vên e dá assistência... } \\
\text { nós jà tivemos e inclusive ea ja participei ai (sobre os cursos) }\end{array}$ \\
\hline \multicolumn{3}{|l|}{ O Lote (contmuacão) } \\
\hline Abertura do lote & $\bar{x}$ & $\begin{array}{l}\text { o servico de topografia do ltesp, nós ajudemos eles com foice, com enxada, com machado... pra fazer as } \\
\text { demarcaça, nós ia, fazia o buraco, coisa e tal } \\
\text { mas a destoce praticamente não foi feita agora. Isto aqui foi feito ja quando nós viemos... a } 5 \text { anos atras, ai nós }\end{array}$ \\
\hline
\end{tabular}




\begin{tabular}{|c|c|c|}
\hline & & 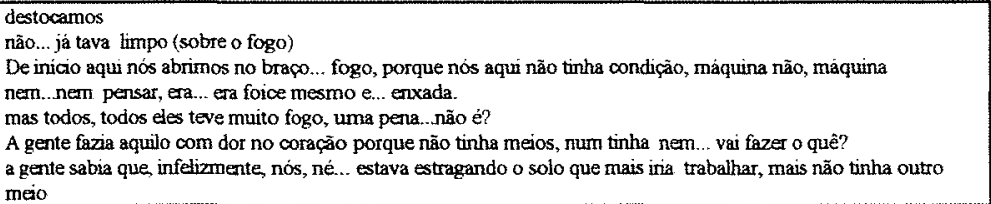 \\
\hline ARAMAR & $\bar{Y}$ & o ARAMAR esse mundo de terra aqui, que tem formigueiro que Deus me livre. \\
\hline \multicolumn{3}{|r|}{ (1) } \\
\hline Reciclagern & $\mathrm{Z}$ & $\begin{array}{l}\text {.. eu faço um aprovétamento de casca de laranja, de banana, como se diz, paitha de milho, cana, não perco nada, } \\
\text { nada absolutumente, por que lógico, são adubo orgânico }\end{array}$ \\
\hline Agrotóxicoss & $\mathrm{Z+1}$ & $\begin{array}{l}\text { Nós ja estamos precisando... muita formiga... năo é? } \\
\text { E nas plantaçao também... e como e que diz... é acaro, é tanta coisa que nós temos aqui contra..nāo é? que nós } \\
\text { precisamos usar... agrotóxico. }\end{array}$ \\
\hline Lixolixo & $\mathrm{Z}+2$ & 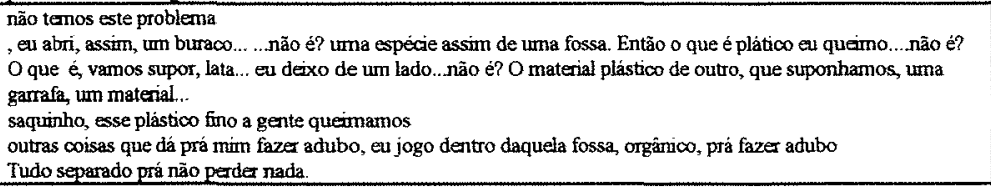 \\
\hline Fauna & $\mathrm{Z}+3$ & $\begin{array}{l}\text { aparece, não é?e... infelizmente (risos), em extinçăo... ñ̃o è? } \\
\text { matou, matou muito, é urna pena... Prá comer. } \\
\text { ou matava ou nós morria de fome (nisos). }\end{array}$ \\
\hline Informaçäo & & 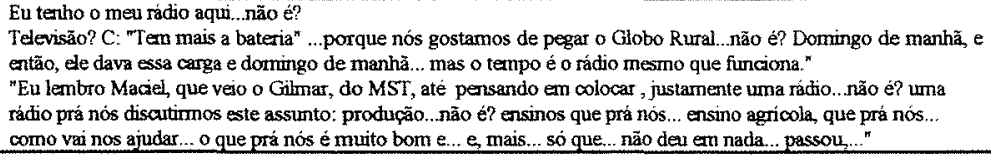 \\
\hline \multicolumn{3}{|r|}{ 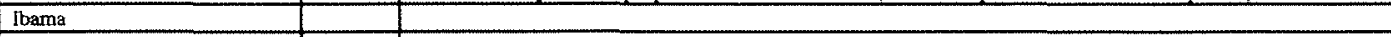 } \\
\hline \multicolumn{3}{|l|}{ Incra } \\
\hline Participaçào atual & $\mathrm{C} 21$ & 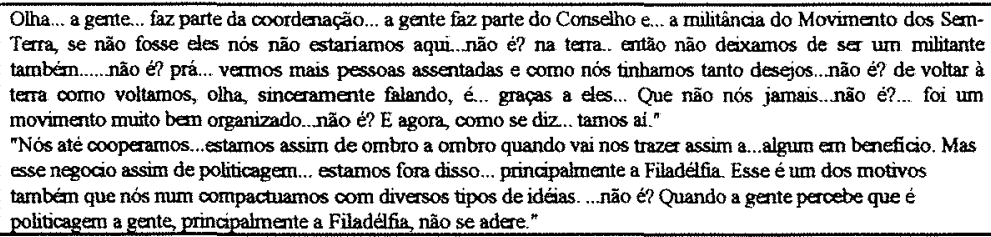 \\
\hline Reforma agráia hoje & $\mathrm{C} 22$ & 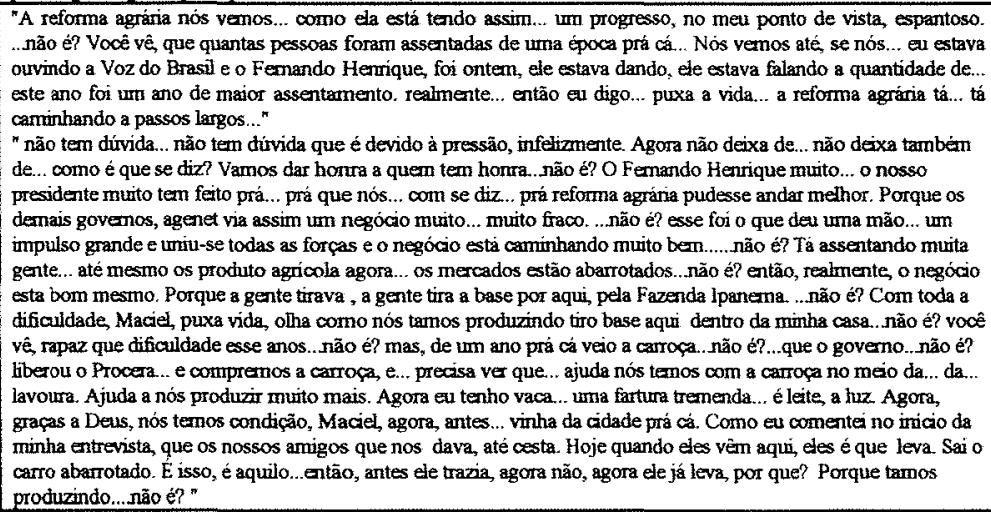 \\
\hline
\end{tabular}




\section{ANEXO D}

\section{Afirmativas sobre a floresta}

1. É um projeto agropecuário

2. Os lotes são pequenos para comportar reservas florestais em seu interior

3. A preservação das florestas existentes na vizinhança (IBAMA/ARAMAR) é importante.

4. O IBAMA tem muita reserva 5.000 hectares

5. A preservação das reservas internas ao assentamento é importante para a proteção da fauna.

6. Deve-se preservar a fauna

7. A caça já foi muito intensa e tolerada.

8. A caça hoje já não é tão praticada

9. O Conselho e as instituições estãosempre conscientizando contra a caça

10.A preservação das reservas internas ao assentamento é importante para a proteção das águas.

11.Deve-se recuperar e enriquecer as reservas internas (legais/obrigatórias)

12.Deve-se estudar a viabilidade de projetos de uso sustentável das reservas legais

13.Deve-se realizar plantios arbóreos com fins paisagísticos

14.Deve-se realizar plantios arbóreos com fins madeireiros

15.Deve-se realizar plantios arbóreos com fins de quebra vento

16.Deve-se realizar plantios arbóreos com fins de alimentação da fauna (peixes)

17.Deve-se realizar plantios arbóreos com fins de melhorar a qualidade da água das represas

18. Deve-se realizar plantios arbóreos nos pastos com fins de sombreamento do rebanho

19.Deve-se realizar plantios arbóreos nas cercas e divisas

20.Deve-se realizar plantios arbóreos com espécies frutíferas para consumo nas reservas

21.Deve-se realizar plantios arbóreos com espécies frutiferas para consumo

22.Deve-se realizar plantios arbóreos em torno das residências

23.Deve-se realizar plantio de palmito nas reservas 
24.Deve-se realizar plantio de eucaliptos nas áreas falhadas das reservas

25.As áreas produtivas já haviam sido todas desmatadas antes da ocupação

26.É inviável a sobrevivência em pequenas áreas de florestas

27.A sobrevivência só é viável em grandes áreas de florestas (extrativismo)

28.Em plantios arbóreos utilizar essencias nativas (árvores de lei)

29.Em plantios arbóreos utilizar essencias exóticas: eucaliptos e pinho

30.Deve-se realizar preparo do solo antes de realizar plantios arbóreos

31.Efetivar trabalhos conjuntos IBAMA/Assentamento visando a preservação das matas e reservas

32.Deve-se respeitar os 30 metros das reservas obrigatórias

33. A água é uma riqueza

34. Soltar animais de criação nas reservas dá punição

35. Aproveitar as reservas hoje está complicado. Faltam informações e tecnologia

36.0 IBAMA se propõe a trabalhar junto: fazer aceiros, emprestar maquinário...

37. A ESALQ diz que é viável o manejo sustentado das reservas

38.No morro do IBAMA não cabe mais ocupação de terras pois só tem morro e pedra

39.É proibido tirar ou cortar a mata nativa

40.0 IBAMA tem muita madeira para serraria (eucaliptos)

41.O IBAMA as vezes corta o eucaliptos

42.0 eucalipto do assentamento para tirar tábua está acabando

43. As terras do IBAMA próximas a George Oetere deveriam ser para Reforma Agrária 44.0 eucalipto do IBAMA é bom para quem é dono dele

45.0 eucalipto cria formiga

46.0 eucalipto resseca a terra

47. Na hora de se vender madeira não compensa

48. Sombreamento da mata é prejuízo para a lavoura

49.Mata próxima à cidade é esconderijo para bandidos (lugar de fumar maconha e crack) 50. Animais da fauna nativa vem comer as galinhas 


\section{ANEXO E}

Contexto dos lotes individuais definitivos: matriz de dificuldades e soluções encontradas

\begin{tabular}{|c|c|c|}
\hline ASSENTADO & DIFICULDADES & SOLUÇÕES REALIZADAS \\
\hline José & $\begin{array}{l}\text { - Falta água no lote; } \\
\text { - necessidade de fazer calagem e adubar } \\
\text { - falta de recursos financeiros } \\
\text { - atraso na liberação do PROCERA } \\
\text { - Não tem lugar para se jogar o lixo }\end{array}$ & $\begin{array}{l}\text { Construiu } 2 \text { cacimbas (bacias) } \\
\text { - grupo faz o projeto junto mas realiza } \\
\text { individual; } \\
\text { - queima o lixo no terreno } \\
\text { - uso de agrotóxico na lavoura }\end{array}$ \\
\hline Toinho & $\begin{array}{l}\text { - Dificuldades de deslocamentos; } \\
\text { - Não tem água no lote } \\
\text { - } 42 \text { familias para administrar um trator; } \\
\text { - solo arenoso para a perfuração de poços } \\
\text { - lixo já é problema } \\
\text { - agrotóxico tem pouco uso no assentamento }\end{array}$ & $\begin{array}{l}\text { - Resolveu entrar no projeto de bicho da seda; } \\
\text { - mina nos fundos do lote (terras do IBAMA) } \\
\text { - um local no quintal só para queimar o lixo } \\
\text { - conscientização nas reuniões sobre o perigo }\end{array}$ \\
\hline Walter & $\begin{array}{l}\text { - Dificuldades na comercialização dos } \\
\text { produtos; } \\
\text { - quem compra a mandioca não paga; } \\
\text { - muita formiga na terra; } \\
\text { - falta de recursos na hora de abrir o lote; } \\
\text { - declara não ter problema com lixo }\end{array}$ & $\begin{array}{l}\text { - uso de gergilim; } \\
\text { - pegar dinheiro com familiares para pagar o } \\
\text { banco; } \\
\text { - queima o plástico, separa vidro e lata } \\
\text { - lixo orgânico para fazer adubo orgânico }\end{array}$ \\
\hline João & 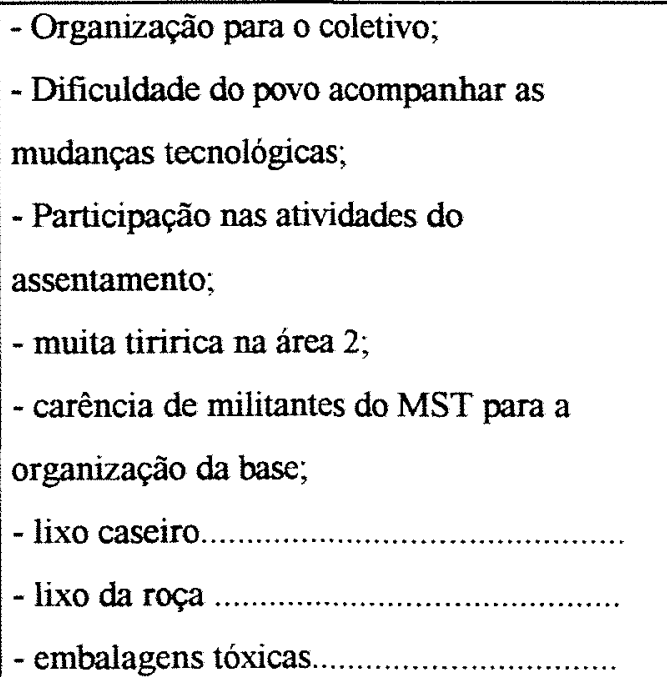 & $\begin{array}{l}\text { - Os problemas do grupo são resolvidos no } \\
\text { grupo; } \\
\text { - trabalho de forma diversificada } \\
\text { - venda direto ao consumidor na feira; } \\
\text { - adubação em covas; } \\
\text { - plantio de fruticultura sobre a tiririca } \\
\text { - amontoa e queima } \\
\text { - mais descuidado } \\
\text { - deveria ter um local mais adequado }\end{array}$ \\
\hline
\end{tabular}


Contexto dos lotes individuais definitivos: matriz de dificuldades e soluções encontradas (continuação)

\begin{tabular}{|c|c|c|}
\hline ASSENTADO & DIFICULDADES & SOLUÇÕES REALIZADAS \\
\hline Chico & 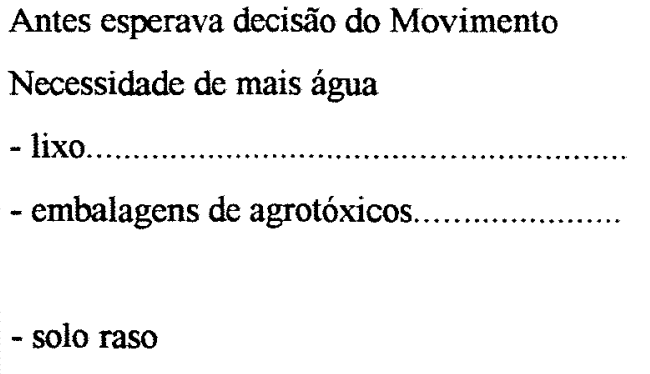 & $\begin{array}{l}\text { - não separa nada, enterra tudo } \\
\text { - guarda em lugares mais alto para proteger de } \\
\text { crianças } \\
\text { - análise de solo }\end{array}$ \\
\hline Manoel & $\begin{array}{l}\text { - Ano ruim para a lavoura, baixa produção; } \\
\text { - Apoio para serviços } \\
\text { - falta de energia elétrica } \\
\text { - falta um trator de qualidade para o grupo; } \\
\text { - pouco recurso para aplicação na terra; } \\
\text { - embalagens de agrotóxicos }\end{array}$ & $\begin{array}{l}\text { - colheu só mandioca } \\
\text { - improvisar gambiarra para tirar luz IBAMA } \\
\text { - um poço no bico um pouco na enxada } \\
\text { - Improvisando com coisas velhas ou } \\
\text { emprestadas; } \\
\text { - joga na fossa, num buraco }\end{array}$ \\
\hline Tião & $\begin{array}{l}\text { - Animais pisoteiam a lavoura; } \\
\text { Necessidade de água } \\
\text { - lixo e embalagens de agrotóxico } \\
\text { - terra fraca. }\end{array}$ & $\begin{array}{l}\text { - Comprou um trator com mais cinco pessoas; } \\
\text { - plantou mamona e feijão com o grupo; } \\
\text { - enterrado ou jogado em lugar que não ofenda }\end{array}$ \\
\hline Roberto & $\begin{array}{l}\text { - Falta de emprego para os filhos na região; } \\
\text { - falta de recursos na hora de abrir o lote; } \\
\text { - falta de informação e tecnologia; } \\
\text { - falta de recursos na hora de abrir o lote; } \\
\text { - lixo } \\
\text { - água }\end{array}$ & $\begin{array}{l}\text { - usei recurso do PROCERA para despesas; } \\
\text { - aprender vendo os outros trabalhando; } \\
\text { - Plantei quiabo, feijão, arroz e mandioca. } \\
\text { - reune tudo e queima } \\
\text { - joga vidro e plástico num poço } \\
\text { - duas nascente em baixo do lote }\end{array}$ \\
\hline
\end{tabular}




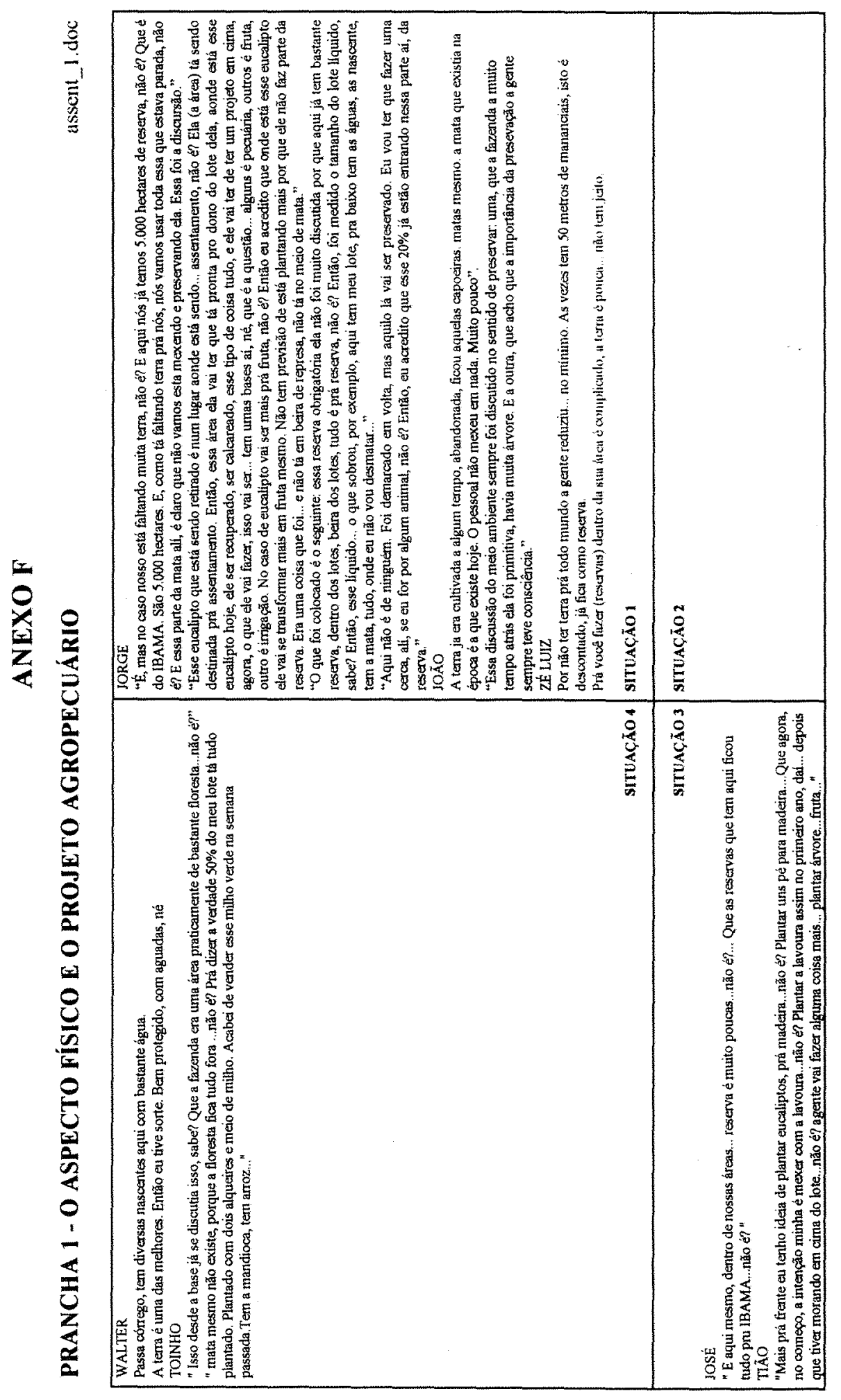




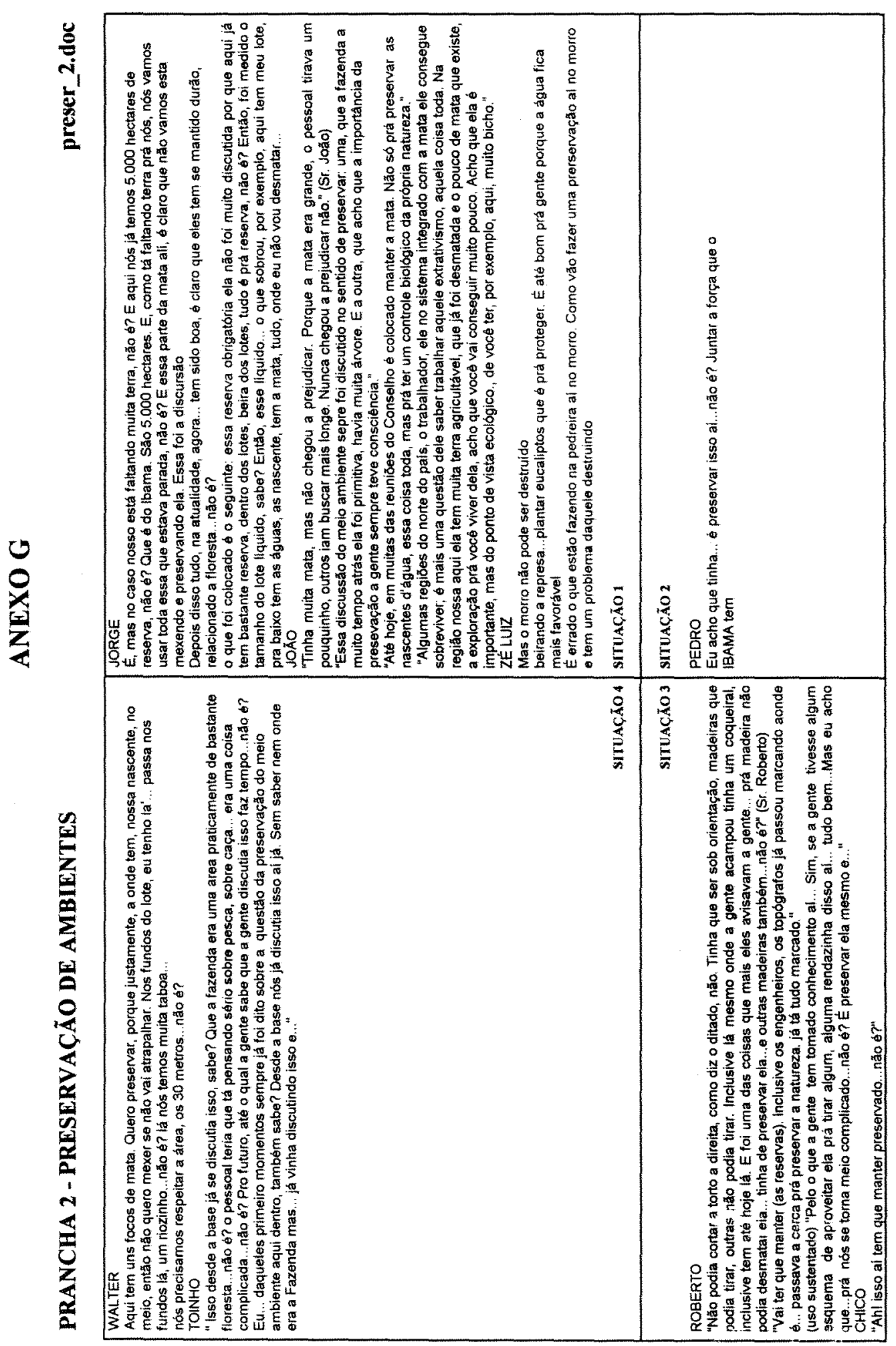




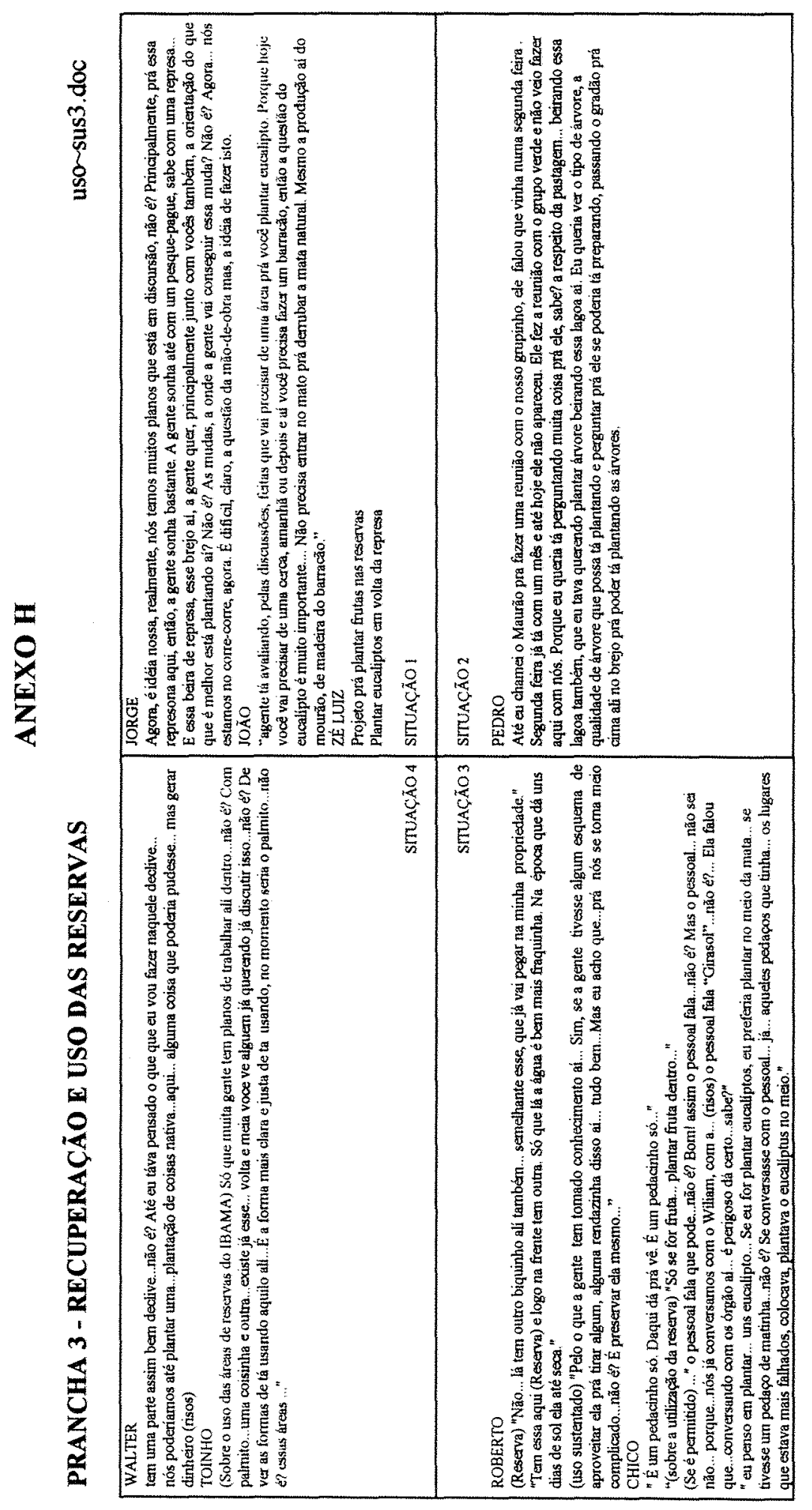




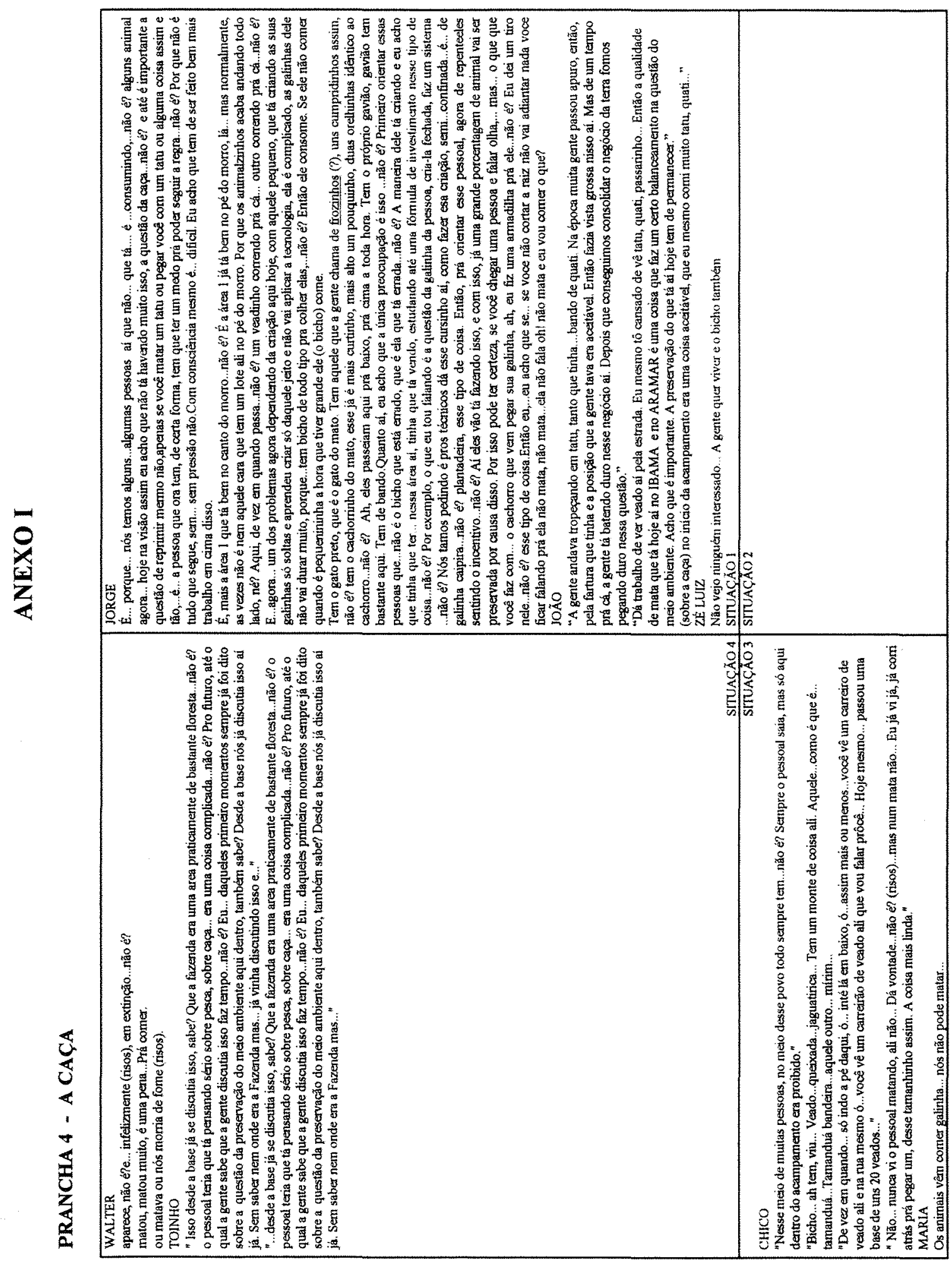




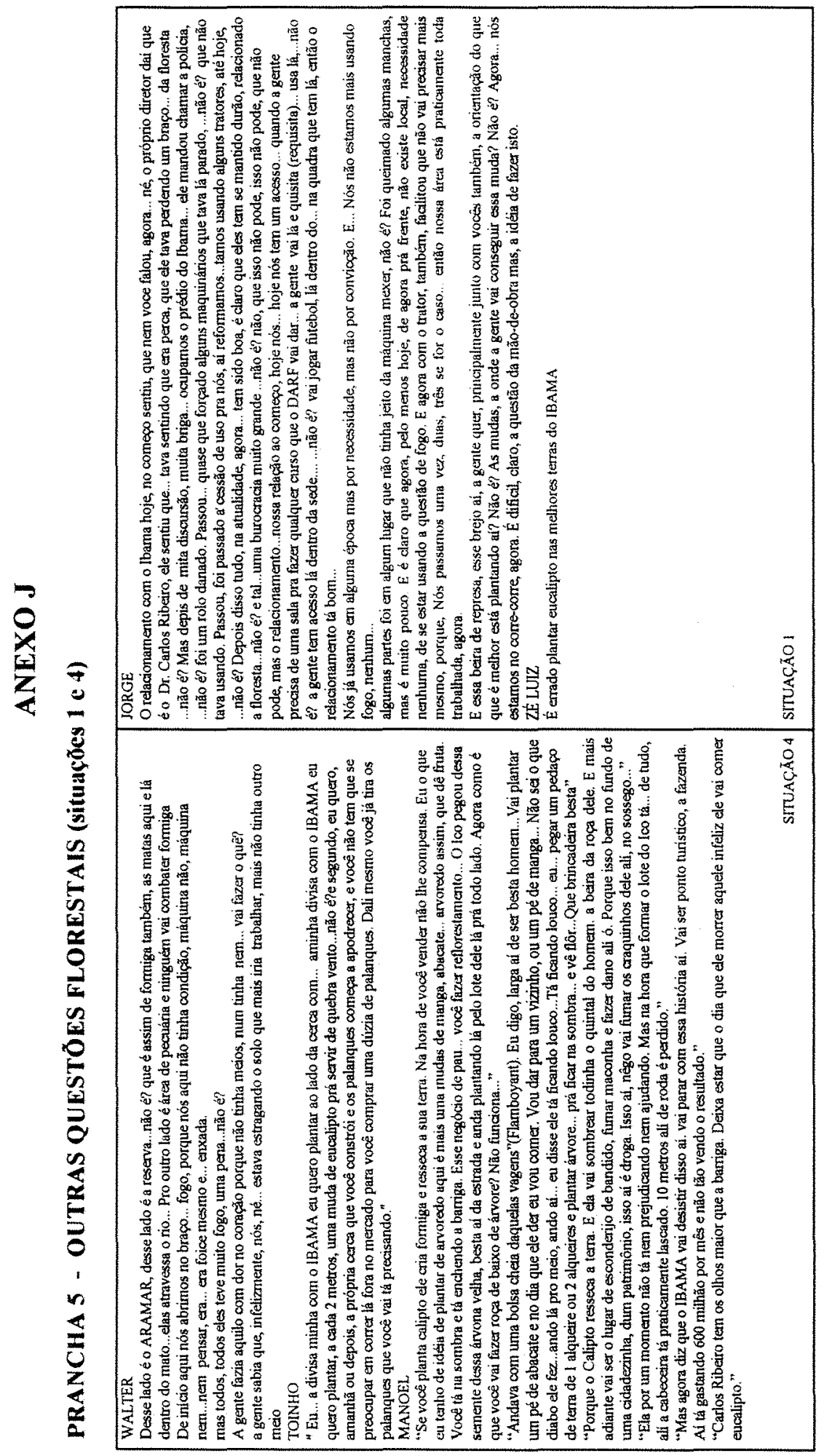




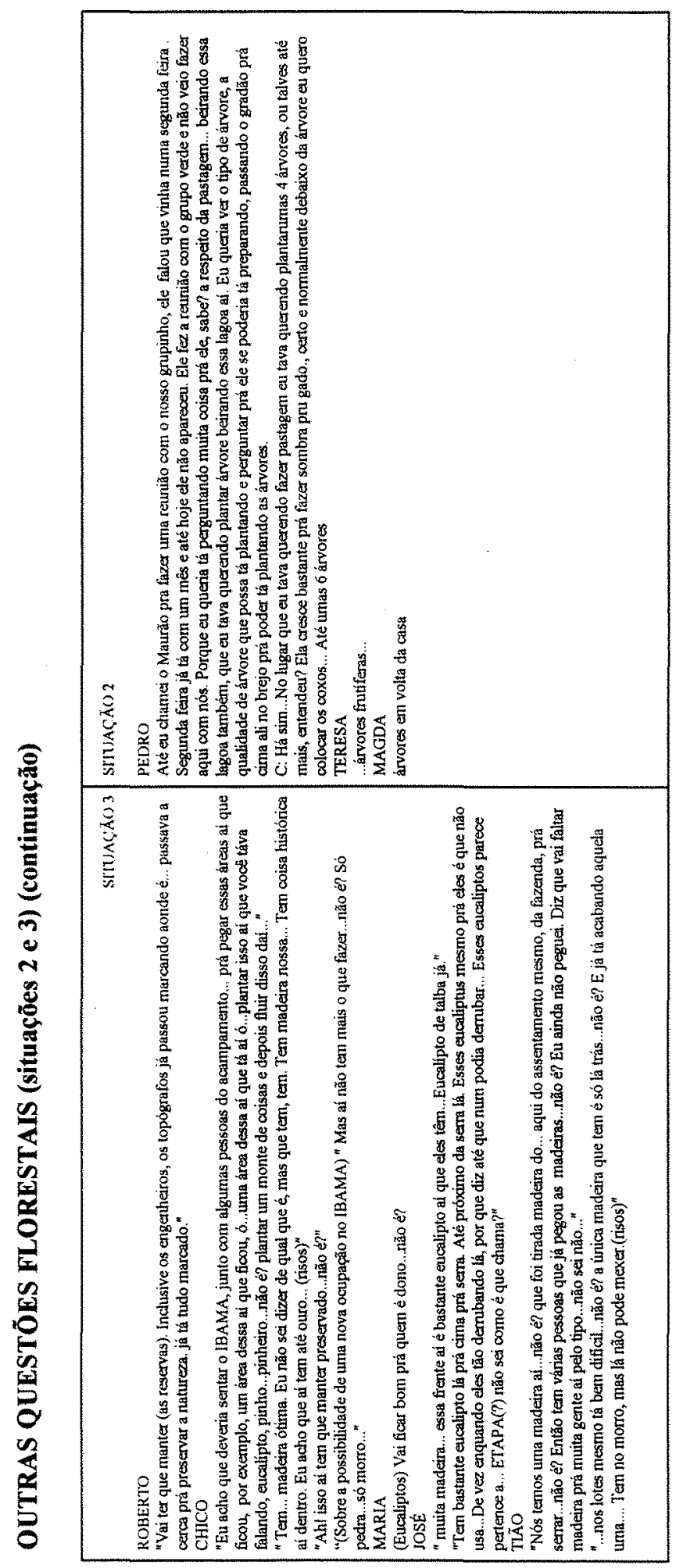




\section{REFERÊNCIAS BIBLIOGRÁFICAS}

AGOSTINHO, V. ONG quer mais verba por mata preservada. Folha de São Paulo, São Paulo, 20 nov. 1996, p.3-7.

ARRUDA, A. Uma contribuição às novas sensibilidades com relação ao meio ambiente: representações sociais de grupos ecologistas e ecofeministas cariocas. São Paulo, 1995. 548p. Tese (Doutorado) - Instituto de Psicologia, Universidade de São Paulo.

BARDIN L. Análise de conteúdo. Lisboa: Edições 70, 1979. 229p.

BUARQUE, C. Modernidade, desenvolvimento e meio ambiente. Brasilia: Instituto Brasileiro do Meio Ambiente e dos Recursos Naturais Renováveis, 1996. 40p. (Série meio ambiente em debate, 2).

CANUTO, J.C.; SILVEIRA, M.A. da; MARQUES, J.F. Sentido da agricultura familiar para o futuro da agroecologia. Ciência e Ambiente, Santa Maria, v.1, n.1, p.57-63, jul., 1994.

CARDOSO, R. (Org.). A aventura antropológica: teoria e pesquisa. Rio de Janeiro: Paz e Terra, 1986. 156p.

CARVALHO, P.E.R. Espécies florestais brasileiras: recomendações silviculturais, potencialidades e uso da madeira. Colombo: EMBRAPA/CNPF; Brasília: EMBRAPA/SPI, 1994. 640p.

CASTELO BRANCO, M.T. Dinâmica da organização camponesa do grupo do Urucum, Corumbá, Mato Grosso do Sul. Viçosa:Universidade Federal de Viçosa, 1989. 124p. Dissertação (M.S.) - Universidade Federal de Viçosa.

DEBERT G.G. Problemas relativos à utilização da história de vida e história oral. In: CARDOSO, R. (Org.) A aventura antropológica: teoria e pesquisa. Rio de Janeiro: Paz e Terra, 1986. 156p.

DEMO, P. Metodologia científica em ciências sociais. São Paulo: Atlas, 1985. 255p.

D'INCAO, M.C. Assentamentos: estado, trabalhadores e meio ambiente. Revista Universidade e Sociedade, v.2, n.4, p. 101-4, dez., 1992. 
D’INCAO, M.C.; ROY, G. Nós, cidadãos: aprendendo e ensinando a democracia. Rio de Janeiro: Paz e Terra, 1995. 277p.

DIAS, G. F. Educação Ambiental: princípios e práticas. S.1.: Gaia, 1992. 399p.

DIEGUES, A.C. O mito moderno da natureza intocada. São Paulo: Hucitec, 1996. $169 \mathrm{p}$.

D'INCAO e MELLO, M.C. O bóia fria: acumulação e miséria. 3.ed. Petrópolis: Vozes, 1976. $154 \mathrm{p}$.

DURKHEIM, E. As formas elementares da vida religiosa (1912). In: GIANNOTT, J.A. (Org.). Durkheim. São Paulo: Abril Cultural, 1978. (Coleção os pensadores).

ENGELS, F. Sobre o papel do trabalho na transformação do macaco em homem. In: MARX, K.; ENGELS, F. Textos. São Paulo: Ed. Sociais, 1975. p.63-74.

ERMIRIO pede a FHC ajuda para construir usina. Folha de São Paulo, São Paulo, 17 nov. 1995. p. $2-5$

ESCOLA SUPERIOR DE AGRICULTURA LUIZ DE QUEIRÓZ. Normas para elaboração de dissertação e teses. 2.ed. Piracicaba, 1997. 94p.

FERNANDES, F. Sociedade de classes e subdesenvolvimento. 2.ed. Rio de Janeiro: Zahar, 1972. 267p.

FERNANDES, B.M. MST: formação e territorialização. São Paulo: Hucitec, 1996. $285 p$.

FERREIRA, L. da C. Os fantasmas do vale: qualidade ambiental e cidadania. Campinas, Ed. da UNICAMP, 1993. 188p.

VAZ, L. Jungmann tenta evitar novo fracasso na reforma agrária. Folha de São Paulo, São Paulo, 03 ago. 1996. p.1-9.

FURTADO, C. O Brasil pós-“milagre”. 8.ed. São Paulo: Paz e Terra, 1983. 152p.

FREIRE, P. Educação e mudança. São Paulo: Paz e Terra, 1983. 79p.

FREIRE, P.; GADOTTI, M.; GUIMARÃES, S. Pedagogia: diálogo e conflito. 3.ed. São Paulo: Cortez, 1989. 127p.

GAUDIANO, E.G. Educación ambiental: historia y conceptos a veite años de Tbilisi. Mexico: s. ed., 1997. 290p. 
GODINHO, F. Amazônia sofre degradação. Folha de São Paulo, São Paulo, 21 jan. 1996. P. 5-14.

GORENDER, J. O pior já passou. Folha de São Paulo, São Paulo, 20 out. 1996. p.1-3. GUARESCHI, P.; JOVCHELOVITCH, S. Introdução. In: JOVCHELOVITCH, S.; GUARESCHI, P. (Orgs.) Textos em representações sociais. Petrópolis: Vozes, 1994. p. $17-25$.

IANNI, O. Origens agrárias do estado brasileiro. São Paulo: Brasiliense, 1984. 255p.

INSTITUTO DE PROMOÇÃO AMBIENTAL. Agenda 21: Documentos da Conferência das Nações Unidas sobre o Ambiente Humano. s.l.: s.ed. 1993. (Versão portuguesa) JODELET, D. Représentation sociale: phénomènes, concept et théorie. In: MOSCOVICI, S. (Org.) Psychologie sociale. Paris: Presses Universitaires de France, 1984.

JONES, A da S. Legitimação privilegiada. Folha de São Paulo, São Paulo, 22 jul. 1996. p. 2.

JODELET, D. Representação social: fenômenos, conceito e teoria. Rio de Janeiro: Fundação Getúlio Vargas, 1988. 42p. Apostila.

JOVCHELOVITCH, S.; GUARESCHI, P. (Org.) Textos em representações sociais. Petrópolis: Vozes, 1994. 324p.

LAGO, D.J.P. Uso medicinal de plantas nativas. In: CONGRESSO FLORESTAL PANAMERICANO, 1; CONGRESSO FLORESTAL BRASILEIRO, 7., Curitiba, 1993. Anais. São Paulo: Sociedade Brasileira de Silvicultura, 1993. v.3, p.239.

LEWIN, K. Teoria de campo em ciências sociais. São Paulo: Pioneira, 1965. 377p.

LÜDKE, M; ÁNDRE, M.E.A. Pesquisa em educação: abordagens qualitativas. São Paulo: EPU, 1986. 99p.

MACHADO, A.M.B. Relatório final do Projeto de Pesquisa Educação Ambiental na Embrapa/Florestas. Colombo: EMBRAPA-CNPF, 1994. (16.0.94.171.23).

Representações sociais sobre o ambiente e educação ambiental num assentamento rural. In: CONVENCION INTERNACIONAL SOBRE MEDIO AMBIENTE Y DESARROLLO, 1; CONGRESSO DE EDUCACIÓN AMBIENTAL PARA O DESARROLLO SOSTENIBLE, Habana, 1997. Programa/Resumenes. Habana: UNESCO/PNUMA, 1997. p.77-78. 
MARX, K. O capital: crítica da economia política. Rio de Janeiro: Civilização Brasileira, 1968. v.2.

MARTINS, J. de S. A chegada do estranho. São Paulo: Hucitec, 1993. 179p.

MARTINS, J. de S. Os camponeses e a política no Brasil. Petrópolis: Vozes, 1981. $231 \mathrm{p}$

MEDICI, A.C. Marx e o meio ambiente. In: FIGUEIREDO, E. de L.; CERQUEIRA FILHO, G.; KONDER, L. (Orgs.) Por que Marx?. São Paulo: Graal, 1993.

MINAYO, M.C. de S. O desafio do conhecimento: pesquisa qualitativa do conhecimento.

4.ed. São Paulo: Hucitec; Rio de Janeiro: Abrasco, 1996. 269p.

MOITINHO, W.G. A "ocupação" da Fazenda Ipanema pelos trabalhadores rurais 'Sem-Terra': uma pequena análise. Piracicaba, 1995. Apostila.

MOSCOVICI, S. La psychanalyse: son image et son public. S.l.: s.ed., 1961. 1v. A representação social da psicanálise. Rio de Janeiro: Zahar, 1978. lv.

PRADO JUNIOR, C. História econômica do Brasil. 32.ed. São Paulo: Brasiliense, 1985. $364 \mathrm{p}$.

PRADO JUNIOR, C. Formação do Brasil contemporâneo. 19.ed. São Paulo: Brasiliense, 1986. 390p.

REIGOTA, M. Meio ambiente e representação social. São Paulo: Cortez, 1995. 86p. (Questões da Nossa Época, 41).

SÁ, C.P de. Núcleo central das representações sociais. Petrópolis: Vozes, 1996. 189p.

SCHULER, A.E. Relatório de vivência agronômica. Piracicaba: ESALQ, 1995. 48p.

SCHUMACHER, E.F. O negócio é ser pequeno. 4.ed. Rio de janeiro: Zahar, 1981. 261p.

SELLTIZ, C.; WRIGHTSMAN, L.S.; COOK, S.W. Métodos de pesquisa nas relações sociais. São Paulo: EPU, 1987. 117p.

SOUZA, P.F. Apontamentos florestais. Rio de Janeiro: Ministério da Agricultura, 1957. v.11. Separata.

SPINK, M.J. (Org.) O conhecimento no cotidianos: as representações sociais na perspectiva da psicologia social. São Paulo: Brasiliense, 1993. 311p. 
STÉDILE, J.P. (Org.). A questão agrária hoje. Porto Alegre: Ed. da UFRGS, 1994. $322 p$.

SORRENTINO, M.; TRAJBER, R.; BRAGA, T. (Orgs.) Cadernos do III Fórum de educação ambiental. São Paulo: Gaia, 1995. 245p.

THIOLLENT M. Metodologia da pesquisa-ação. São Paulo: Cortez/Autores Associados, 1985. $107 \mathrm{p}$.

THOMAS K. O homem e o mundo natural. São Paulo: Companhia das Letras, 1988. $454 \mathrm{p}$.

THOMPSON, W.I. (Org.). Gaia: uma teoria do conhecimento. São Paulo: Gaia, 1990. $203 p$.

TODD, J. Uma categoria econômica baseada na ecologia. In: THOMPSON, W.I. (Org.). Gaia: uma teoria do conhecimento. São Paulo: Gaia, 1990. p.124.

TORRES, C.A. A práxis educativa de Paulo Freire. São Paulo: Loyola, 1979. 150p.

TORRES, S. Mata Atlântica volta a crescer no Rio. Folha de São Paulo, São Paulo, 28 Jul. 1996. p.3-8

VEIGA, J.E. O que é reforma agrária. 2.ed. São Paulo: Abril Cultural/Brasiliense, 1984. 87p. (Coleção Primeiros Passos, 33).

WICKERT, M.L.S. Pequeno manual de educação ambiental: uma abordagem sistêmica. Brasilia: Funatura, 1992. 55p.

WILLIAMS, R. O campo e a cidade: na história e na literatura. São Paulo: Companhia das Letras, 1989. 439p. 